\title{
Depreciatie van menselijk kapitaal
}

Citation for published version (APA):

Fouarge, D., \& de Grip, A. (2011). Depreciatie van menselijk kapitaal. Researchcentrum voor Onderwijs en Arbeidsmarkt, Faculteit der Economische Wetenschappen. ROA Reports No. 1

https://doi.org/10.26481/umarep.2011001

Document status and date:

Published: 01/01/2011

DOI:

10.26481/umarep.2011001

Document Version:

Publisher's PDF, also known as Version of record

\section{Please check the document version of this publication:}

- A submitted manuscript is the version of the article upon submission and before peer-review. There can be important differences between the submitted version and the official published version of record.

People interested in the research are advised to contact the author for the final version of the publication, or visit the DOI to the publisher's website.

- The final author version and the galley proof are versions of the publication after peer review.

- The final published version features the final layout of the paper including the volume, issue and page numbers.

Link to publication

\footnotetext{
General rights rights.

- You may freely distribute the URL identifying the publication in the public portal. please follow below link for the End User Agreement:

www.umlib.nl/taverne-license

Take down policy

If you believe that this document breaches copyright please contact us at:

repository@maastrichtuniversity.nl

providing details and we will investigate your claim.
}

Copyright and moral rights for the publications made accessible in the public portal are retained by the authors and/or other copyright owners and it is a condition of accessing publications that users recognise and abide by the legal requirements associated with these

- Users may download and print one copy of any publication from the public portal for the purpose of private study or research.

- You may not further distribute the material or use it for any profit-making activity or commercial gain

If the publication is distributed under the terms of Article $25 \mathrm{fa}$ of the Dutch Copyright Act, indicated by the "Taverne" license above, 


\title{
Depreciatie van menselijk kapitaal
}

\author{
Didier Fouarge
}

Andries de Grip

ROA-R-2011/1 


\section{Colofon}

(C) Researchcentrum voor Onderwijs en Arbeidsmarkt (ROA). Niets uit deze uitgave mag op enige manier worden verveelvoudigd zonder voorafgaande schriftelijke toestemming van de directeur van het ROA.

\section{Researchcentrum voor Onderwijs en Arbeidsmarkt}

School of Business and Economics

Maastricht University

\section{Vormgeving}

ROA secretariaat, Maastricht

\section{Verkoop}

Researchcentrum voor Onderwijs en Arbeidsmarkt email: secretary-roa-sbe@maastrichtuniversity.nl website: www.roa.nl

ISBN: 978-90-532I-492-3

januari 20II 


\section{Inhoud}

\section{Voorwoord}

Samenvatting

vii

1 Inleiding

2 Eerder onderzoek 3

2.1 Inleiding 3

2.2 Depreciatie vanuit een menselijk kapitaal model 3

2.3 Maatstaven voor depreciatie van menselijk kapitaal $\quad 8$

$\begin{array}{lll}2.4 & \text { Empirische studies naar slijtage van menselijk kapitaal } & 10\end{array}$

2.5 Empirische studies naar atrofie van menselijk kapitaal 11

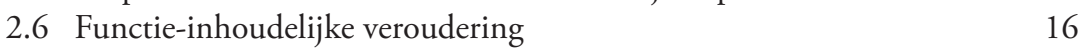

$\begin{array}{ll}2.7 \text { Sector- en bedrijfsspecifieke veroudering } & 17\end{array}$

$\begin{array}{ll}2.8 \text { Conclusie } & 19\end{array}$

3 Depreciatie van menselijk kapitaal over de levensloop 23

$\begin{array}{ll}3.1 \text { Inleiding } & 23\end{array}$

$\begin{array}{lll}3.2 \text { Data } & 24\end{array}$

$\begin{array}{ll}3.3 \text { Geletterdheid over de levensloop } & 27\end{array}$

3.4 Cognitief vermogen op oudere leeftijd 34

3.5 Eigen inschatting van het kennisniveau over de levensloop 36

3.6 Conclusie en discussie 44

4 Depreciatie van menselijk kapitaal door loopbaanonderbrekingen vanwege zorgtaken

$\begin{array}{ll}4.1 \text { Inleiding } & 47\end{array}$

$\begin{array}{lll}4.2 \text { Data } & 48\end{array}$

4.3 Kans op herintrede 49

4.4 Beroepsniveau en loopbaanonderbrekingen 55

$\begin{array}{ll}4.5 \text { Conclusie } & 57\end{array}$ 
5 Effect van werkloosheid op depreciatie van menselijk kapitaal 59

$\begin{array}{lll}5.1 & \text { Inleiding } & 59\end{array}$

$\begin{array}{lll}5.2 \text { Data } & 60\end{array}$

$\begin{array}{lll}5.3 \text { Beschrijvende statistieken } & 61\end{array}$

5.4 Participatie en loon voor en na ontslag 65

$\begin{array}{ll}5.5 \text { Schattingsresultaten } & 69\end{array}$

$\begin{array}{ll}5.6 \text { Conclusie } & 74\end{array}$

$\begin{array}{lll}6 & \text { Conclusie en vervolgvragen } & 77\end{array}$

$\begin{array}{ll}\text { Bijlagen } & \mathbf{8 1}\end{array}$

Bijlage 1: gemiddelde en variantie van plausibele waarden $\quad 81$

$\begin{array}{ll}\text { Bijlage 2: Bedrijfseconomisch ontslag } & 83\end{array}$

$\begin{array}{lr}\text { Literatuur } & 85\end{array}$ 


\section{Voorwoord}

In een kenniseconomie is het menselijk kapitaal van werknemers van grote waarde. Menselijk kapitaal kan echter snel verouderen, bijvoorbeeld als bepaalde vaardigheden onvoldoende gebruikt worden, of als vernieuwingen van het productieproces nieuwe competenties vereisen. Dit rapport, dat geschreven is in opdracht van het Ministerie van Economische Zaken, Landbouw en Innovatie, gaat in op de ontwikkeling van menselijk kapitaal gedurende iemands levensloop. Er wordt daarbij in het bijzonder ingegaan op het effect van werkloosheid en inactiviteit vanwege zorgtaken op de waarde van het menselijk kapitaal.

Onderzoek naar de waardevermindering van menselijk kapitaal gebruikt doorgaans loongegevens of de arbeidsparticipatiekans als indicator. Behalve deze standaard indicatoren, maakt dit onderzoek ook gebruik van testen van iemands basisvaardigheden op gebied van taal, tekstbegrip en rekenen (de 'functionele geletterdheid'), geheugentesten en de subjectieve inschatting van de eigen kennisontwikkeling.

Het ROA wil een aantal personen bedanken voor hun input bij de totstandkoming van dit rapport: Jacco van Maldegem van het Ministerie van Economische Zaken, Landbouw en Innovatie voor de begeleiding van het onderzoek, de leden van de klankbordgroep (Anja Deelen, Henk Nijboer, Rik Dillingh, Ted Reininga, Arjan Uwland) en Sjef Ederveen voor hun commentaar op eerdere versies van dit rapport. 



\section{Samenvatting}

In een kenniseconomie is het menselijk kapitaal van werknemers van grote waarde. Het menselijk kapitaal kan echter snel verouderen. Deze veroudering kan optreden wanneer bepaalde vaardigheden onvoldoende gebruikt worden en daardoor deels verloren gaan of doordat technologische en organisatorische innovaties van het productieproces nieuwe eisen stellen aan de kennis en vaardigheden van werknemers. In dit rapport wordt ingegaan op de ontwikkeling van iemands menselijk kapitaal gedurende de levensloop. Daarbij wordt in het bijzonder ingezoomd op het effect van inactiviteit vanwege zorgtaken en het effect van werkloosheid op de waarde van het menselijk kapitaal. De onderzoeksvragen luiden als volgt:

- Hoe ontwikkelt de waarde van het menselijk kapitaal zich over de levensloop?

- In welke mate daalt het menselijk kapitaal in waarde in perioden van inactiviteit in verband met de zorg voor kinderen?

- In welke mate daalt het menselijk kapitaal in waarde in perioden van werkloosheid?

- In welke mate verschilt de depreciatie van menselijk kapitaal op de arbeidsmarkt tussen verschillende groepen (bijvoorbeeld naar geslacht, opleidingsniveau, leeftijd, bedrijfssector)?

In dit rapport wordt gebruik gemakt van verschillende indicatoren om veranderingen in de waarde van het menselijk kapitaal te meten:

- testen van functionele geletterdheid,

- cognitieve testen,

- de eigen inschatting van het kennisniveau

voor het in kaart brengen van de waarde van het menselijk kapitaal over de levensloop, en:

- de arbeidsparticipatiekans en

- het loon

- voor het in kaart brengen van de effecten van economische inactiviteit wegens de zorg voor kinderen c.q. werkloosheid.

\section{Conceptueel kader}

In hoofdstuk 2 is een conceptueel kader geschetst, waarbinnen verschillende oorzaken van depreciatie van menselijk kapitaal kunnen worden onderscheiden en de relevante literatuur kan worden besproken. Daarbij is er in eerste instantie een onder- 
scheid gemaakt tussen twee soorten depreciatie: technische veroudering (slijtage en atrofie) en economische veroudering (functie-inhoudelijk veroudering en sector- en bedrijfsspecifieke veroudering). Daarnaast wordt er een onderscheid gemaakt tussen de manieren waarop depreciatie gemeten kan worden. Dit onderscheid vindt plaats langs twee dimensies: objectieve (waarneembaar) versus subjectieve (eigen inschatting) maatstaven en directe (testen) versus indirecte (loon) maatstaven.

Empirisch onderzoek naar de technische veroudering van menselijk kapitaal laat zien dat periodes van inactiviteit gepaard gaan met verlies aan menselijk kapitaal. Ook werkloosheid resulteert in een waardedaling van het menselijk kapitaal. Deze waardedaling manifesteert zich zowel in een lagere participatiekans en een lager loon na herintrede, als in lagere scores op cognitieve en geheugentesten. Uit onderzoek blijkt dat het effect van inactiviteit en werkloosheid op het loon doorgaans blijvend is (de opgelopen depreciatie wordt niet meer volledig ingehaald), maar dat het effect of de participatiekans slechts tijdelijk is (na verloop van tijd zijn de effecten van werkloosheid niet meer merkbaar). Onderzoek laat ook zien dat de effecten van inactiviteit en werkloosheid heterogeen zijn: de gevonden effecten verschillen naar geslacht, leeftijd en beroep. Zo zijn bijvoorbeeld de negatieve gevolgen van werkloosheid sterker voor ouderen dan voor jongeren en de negatieve gevolgen van inactiviteit verschillend tussen mannen en vrouwen, afhankelijk van de institutionele context: in Duitsland ondervinden vrouwen een groter nadeel van inactiviteit dan mannen wat hun arbeidsmarktkansen later in de loopbaan betreft, maar in Zweden is het omgekeerde het geval.

Bij economische veroudering heeft depreciatie van menselijk kapitaal als gevolg van sector- en bedrijfsspecifieke veroudering speciale aandacht gekregen. In empirisch onderzoek is - zij het in beperkte mate - aandacht besteed aan de gevolgen van massaontslag voor de arbeidsmarktkansen en het loon na ontslag. Een kenmerk van werkloosheid door massaontslag is dat het niet de werknemer zelf aangerekend kan worden: er is doorgaans geen sprake van eigen schuld, maar van een bedrijfseconomische reden. Ondanks het feit dat er geen sprake is van eigen schuld laat onderzoek zien dat massaontslag een lager loon tot gevolg heeft. Wel is het zo dat de loonachterstand sneller wordt ingelopen dan bij 'gewone' werkloosheid. Dit duidt op het verloren gaan van bedrijfsspecifiek menselijk kapitaal dat langzamerhand in de nieuwe baan weer wordt opgebouwd. Echter, wanneer de ontslagen werknemer een baan in een andere sector vindt, is de loonachterstand groter dan bij een nieuwe baan in dezelfde sector. Dit lijkt er op te wijzen dat in dat geval ook sectorspecifiek menselijk kapitaal verloren gaat.

De verschillende soorten depreciatie kunnen empirisch gezien niet altijd goed van elkaar worden onderscheiden. Ook zijn er door databeperkingen niet altijd voorbeelden te vinden van studies die depreciatie meten langs de hier onderscheiden dimensies. Desalniettemin komt uit het in hoofdstuk 2 gepresenteerde overzicht van het bestaande empirisch onderzoek naar depreciatie van menselijk kapitaal het beeld 
naar voren dat met name inactiviteit, werkloosheid en onvoldoende gebruik van menselijk kapitaal tot depreciatie van menselijk kapitaal kunnen leiden, ook al zijn de effecten niet altijd gelijk voor alle groepen werknemers.

\section{Menselijk kapitaal over de levensloop}

Het gros van het onderzoek naar depreciatie van menselijk kapitaal maakt gebruik van loongegevens als benadering van het menselijk kapitaal van een werkende. In hoofdstuk 3 kiezen wij voor een ander aanpak waarbij - aansluitend op recente ontwikkelingen in de economische literatuur - de waarde van het menselijk kapitaal aan de hand van directe indicatoren wordt vastgesteld: testen van functionele geletterdheid, cognitieve geheugen testen, en de subjectieve inschatting van de eigen kennisontwikkeling.

De analyses met betrekking tot de functionele geletterdheid - basisvaardigheden op het gebied van taal, tekstbegrip en rekenen - van mensen laten zien dat er gedurende de levensloop sprake is van een afname van de verschillende vormen van geletterdheid. Voor zover iemands functionele geletterdheid een goede indicator is voor zijn of haar menselijk kapitaal, dan is de voorlopige conclusie dat het menselijk kapitaal na het verlaten van het initiële onderwijs op significante wijze deprecieert over de levensloop. Deze depreciatie doet zich vooral voor na de leeftijd van 40 jaar. Ook geheugentesten laten zien dat iemands cognitie op oudere leeftijd afneemt. Deze afname van iemands cognitie is groter bij mensen die uit het arbeidsproces zijn getreden.

De testen van iemands functionele geletterdheid en geheugentesten meten vaardigheden die belangrijk zijn voor het functioneren op het werk en in het dagelijks leven. Functionele geletterdheid is bijvoorbeeld noodzakelijk om schriftelijk informatie en instructies goed te kunnen begrijpen, zelfs in banen op een laag niveau. Toch meet dit natuurlijk slechts een bepaald aspect van iemands menselijk kapitaal. Verschillende productieve vaardigheden zoals bijvoorbeeld communicatieve vaardigheden, of het vermogen om samen te werken staan grotendeels los van iemands functionele geletterdheid. Mede om die reden is in hoofdstuk 3 ook gekeken naar een subjectieve maatstaf voor iemands menselijk kapitaal, namelijk het beeld dat men heeft van de eigen kennisontwikkeling. Uit de analyses van de kennisontwikkeling van de Nederlandse beroepsbevolking komt naar voren dat de kennis met het stijgen van de leeftijd steeds minder toeneemt om vervolgens, rond de leeftijd van 58 jaar zelfs af te nemen. Het is echter belangrijk om op te merken dat het kennisniveau van werkenden niet daalt. Ook blijkt dat de kennis van werkenden die de afgelopen twee jaar cursussen hebben gevolgd significant minder snel deprecieert. Dit effect gaat echter niet op wanneer gecontroleerd wordt voor het al of niet werken in deeltijd. Deeltijdwerk blijkt een sterk negatief effect te hebben op iemands kennisontwikkeling en is ook negatief gecorreleerd met de deelname aan scholing. Het negatieve effect van deeltijdwerk op de kennisontwikkeling is echter geheel toe te schrijven aan de negatieve kennisontwikkeling van werknemers met een middelgrote of kleine deeltijdbaan. De kennis- 
ontwikkeling van werknemers met een grote deeltijdbaan verschilt niet van die van werknemers in een voltijdbaan.

Een belangrijke maatschappelijke vraag in verband met de inzetbaarheid van oudere werknemers, is de vraag in welke mate de ontwikkeling van de directe indicatoren van menselijk kapitaal over de levensloop overeenkomt met de ontwikkeling van het loon. Loon is een meer gangbare en tegelijkertijd een indirecte maatstaf van menselijk kapitaal, die door allerlei sociaal-economische instituties wordt beïnvloed. Het blijkt dat het patroon van de loonontwikkeling over de levensloop opmerkelijke overeenkomsten vertoont met het patroon van de door de betrokkenen zelf gepercipieerde ontwikkeling van zijn of haar kennisniveau. Echter, de objectieve testen met betrekking tot iemands niveau van functionele geletterdheid laten zien dat iemands menselijk kapitaal al op veel jongere leeftijd deprecieert. Hoe kunnen deze bevindingen aan elkaar worden gerelateerd? Ten eerste is het van belang om op te merken dat geletterdheid en cognitieve testscores belangrijke vaardigheden die op de arbeidsmarkt van grote waarde zijn niet meten. Denk bijvoorbeeld aan vaardigheden als flexibiliteit, communicatieve vaardigheden, en dergelijke. Ten tweede meten cognitietesten - en waarschijnlijk ook de functionele geletterdheidtesten - iemands 'fluid intelligence' en niet de 'cristallized intelligence' (Cattell, 1983) waaronder de vakspecifieke kennis en vaardigheden, die zeer bepalend kunnen zijn voor de waarde van iemands menselijk kapitaal.

\section{Loopbaanonderbrekingen vanwege zorgtaken en menselijk kapitaal}

In hoofdstuk 4 zijn wij aan de hand van retrospectieve data ingegaan op het effect van perioden van inactiviteit op de participatiekans en het beroepsniveau later in de loopbaan. De data laten zien dat er zich in de afgelopen Ioo jaar substantiële verschuivingen hebben voorgedaan in de arbeidsparticipatie van vrouwen, terwijl er bij mannen niet veel is veranderd. Vrouwen trekken zich terug uit de sfeer van betaalde arbeid rond het moment dat zij kinderen krijgen, maar jongere cohorten vrouwen doen dit veel minder vaak en ook minder vroeg voor het krijgen van het eerste kind. Toch is de participatiedip rond het krijgen van kinderen bij vrouwen nog steeds substantieel en het zou kunnen leiden tot verlies van menselijk kapitaal dat zich manifesteert door een lagere baankans na de loopbaanonderbreking of door een lager beroepsniveau na uitstroom uit inactiviteit.

De analyses in dit hoofdstuk hebben laten zien dat er sprake is van een negatieve duurafhankelijkheid tussen de periode van inactiviteit wegens zorgtaken en de kans op uitstroom naar betaalde arbeid: wie langer inactief is, komt minder snel aan een baan. Onze analyse laat ook zien dat een langere duur van inactiviteit resulteert in een lager beroepsniveau bij herintrede op de arbeidsmarkt. Dit negatieve effect wordt echter gecompenseerd door de opgebouwde arbeidsmarktervaring in de jaren voor de loopbaanonderbreking. Voor beleid is dit een interessante bevinding, omdat het suggereert dat de vaardigheden die opgedaan zijn in de vorige baan niet geheel verloren gaan 
indien vrouwen zich voor een al dan niet langere tijd terugtrekken uit betaalde arbeid om voor hun kinderen te zorgen. Opmerkelijk is wel dat wanneer vrouwen voor hun loopbaanonderbreking in verband met de zorg voor kinderen werkzaam waren in een specifiek mannen- of vrouwenberoep, zij minder perspectief hebben om na hun loopbaanonderbreking weer een functie op niveau te vinden dan wanneer ze eerder in een gemengd beroep werkzaam waren. De depreciatievoet van menselijk kapitaal is niet verschillend voor gemengde, mannen- en vrouwenberoepen.

\section{Werkloosheid en menselijk kapitaal}

In hoofdstuk 5 wordt ingegaan op de gevolgen van bedrijfseconomisch ontslag voor de arbeidsparticipatie en het loon. Door gebruik te maken van de bij het CBS nieuw ontwikkelde data-infrastructuur, sluit onze analyse aan bij recente ontwikkelingen in de economische literatuur. De CBS data maken het mogelijk om drie vormen van bedrijfseconomisch ontslag te onderscheiden: (I) ontslag via het UWV, (2) faillissementen en (3) collectieve uitstroom. Focussen op bedrijfseconomisch ontslag is interessant, omdat de reden voor het ontslag niet gerelateerd is aan de eigen schuld of specifieke kenmerken van de ontslagene. Bij andere vormen van werkloosheid is dat in meer of mindere mate wel het geval is. De door ons gebruikte databronnen lenen zich dus goed voor het meten van de gevolgen van ontslag op depreciatie van menselijk kapitaal. Immers, 'signaling' van de productiviteit van de werknemer speelt in tegenstelling tot bijvoorbeeld ontslag door schuld geen grote rol. Een kanttekening hierbij is dat onze analyses hebben laten zien dat er wel degelijk verschillen zijn in de achtergrondkenmerken van de ontslagenen en niet-ontslagenen. Hierbij kan worden opgemerkt dat vooral de UWV-ontslagenen, wat hun persoons- en baankenmerken betreft, het meest op de niet-ontslagenen lijken. Vooral de vergelijking van deze twee groepen biedt dus goede mogelijkheden om uitspraken te kunnen doen met betrekking tot depreciatie van menselijk kapitaal als gevolg van werkloosheid.

Onze analyses hebben laten zien dat ontslagwerklozen een kleinere participatiekans hebben in de jaren na ontslag vergeleken met een controle groep. Bovendien hebben onze analyses laten zien dat ontslag via het UWV of als gevolg van een faillissement significante negatieve gevolgen heeft voor het loon dat iemand na het ontslag verdient. Echter, voor de collectief ontslagenen die weer werk vinden wordt een positief looneffect gevonden. Dit lijkt erop te wijzen dat collectief ontslag een gunstig effect heeft op de allocatie van arbeid, maar dit effect kan ook het gevolg zijn van het feit dat deze groep ontslagenen ook personen omvat die vrijwillig hun bedrijf hebben verlaten voor een betere baan elders. 



\section{Inleiding}

In de huidige kenniseconomie kan het menselijk kapitaal snel verouderen. Deze veroudering kan optreden wanneer bepaalde vaardigheden onvoldoende gebruikt worden en daardoor deels verloren gaan. Menselijk kapitaal kan ook verouderen doordat technologische en organisatorische innovaties van het productieproces nieuwe eisen stellen aan de kennis en vaardigheden van werknemers. Het positieve effect van ervaring op de waarde van iemands menselijk kapitaal is dan niet toereikend om het negatieve effect van deze kennisveroudering te compenseren (MacDonald en Weisbach, 2004). Dit suggereert dat in de huidige kenniseconomie de productieve waarde van het menselijk kapitaal over de levensloop vermindert, wanneer werknemers hun competenties niet op peil houden door het opdoen van werkervaring, het informeel leren op het werk, of het volgen van aanvullende scholing. Hierdoor zullen werknemers op oudere leeftijd minder productief zijn dan jongere werknemers die beschikken over een nieuwere jaargang menselijk kapitaal (Neuman en Weiss, 1995). De waardevermindering van menselijk kapitaal treedt in het bijzonder op bij degenen die (al dan niet tijdelijk) niet in het arbeidsproces participeren. De mensen die aan de zijlijn staan hebben immers niet de mogelijkheid om door 'learning by doing' de competenties te verwerven die nodig zijn vanwege de technologische en organisatorische vernieuwingen die zich in vrijwel alle sectoren van de economie voordoen (De Grip, 2006). Borghans e.a. (2007) laten zien dat jongeren die een jaar niet werken een aanzienlijke kennisachterstand oplopen ten opzichte van jongeren die wel werken. De kennisontwikkeling die zij mislopen staat gelijk aan die van een kwart jaar voltijds onderwijs.

In dit rapport wordt ingegaan op de ontwikkeling van iemands menselijk kapitaal gedurende de levensloop. Daarbij wordt in het bijzonder ingezoomd op het effect van inactiviteit en werkloosheid op de waarde van het menselijk kapitaal. De onderzoeksvragen luiden als volgt:

- Hoe ontwikkelt de waarde van het menselijk kapitaal zich over de levensloop?

- In welke mate daalt het menselijk kapitaal in waarde in perioden van inactiviteit in verband met de zorg voor kinderen?

- In welke mate daalt het menselijk kapitaal in waarde in perioden van werkloosheid?

- In welke mate verschilt de depreciatie van menselijk kapitaal op de arbeidsmarkt tussen verschillende groepen (bijvoorbeeld naar geslacht, opleidingsniveau, leeftijd, bedrijfssector)? 
De contributie van het rapport is drieledig. Ten eerste, zijn de analyses deels gebaseerd op directe maatstaven voor de waarde van het menselijk kapitaal - cognitief vermogen, kennisniveau - en bieden daarom een innovatieve aanvulling op de literatuur op dit terrein. Ten tweede, wordt het effect van economische inactiviteit op de waarde van het menselijk kapitaal geanalyseerd op basis van data die de gehele levensloop van werknemers bestrijken. Dit biedt de mogelijkheid om lange termijn effecten in kaart te brengen, en deze effecten te differentiëren naar cohorten van werknemers. Ten derde, wordt het effect van werkloosheid op de waarde van het menselijk kapitaal onderzocht aan de hand van nieuwe data van het Centraal Bureau voor de Statistiek (CBS) die betrekking hebben op mensen die werkloos zijn geworden door massaontslag of faillissement. Dergelijke data maken het mogelijk om depreciatie van menselijk kapitaal als gevolg van werkloosheid vast te stellen, waarbij vertekening door endogeniteit geen grote rol speelt omdat bij collectief ontslag geen sprake is van een selectieproces op basis van de relatief lage productiviteit van de ontslagene. ${ }^{\mathrm{I}}$

In dit rapport wordt gebruik gemaakt van verschillende indicatoren om veranderingen in de waarde van het menselijk kapitaal te meten (zie De Grip en Van Loo, 2002): cognitieve testen en de eigen inschatting van het kennisniveau voor het in kaart brengen van de waarde van het menselijk kapitaal over de levensloop, en de arbeidsparticipatiekans en het loon voor het in kaart brengen van de effecten van economische inactiviteit wegens de zorg voor kinderen c.q. werkloosheid.

Het rapport is als volgt opgebouwd. In hoofdstuk 2 beschrijven wij een conceptueel kader voor de oorzaken van depreciatie van menselijk kapitaal en de wijze waarop depreciatie gemeten kan worden. Het hoofdstuk gaat tevens in op de relevante literatuur. In hoofdstuk 3 gaan wij in op de waardeverandering van het menselijk kapitaal gedurende de levensloop in Nederland. Depreciatie van menselijk kapitaal als gevolg van inactiviteit komt aan bod in hoofdstuk 4. De gevolgen van werkloosheid (als gevolg van massa ontslag of faillissement) voor het menselijk kapitaal komen aan bod in hoofdstuk 5. Hoofdstuk 6 bevat onze beleidsconclusies.

I. In ieder geval is deze selectie minder sterk dan bij ontslag in het algemeen (zie hoofdstuk 5). 


\section{Eerder onderzoek}

\subsection{Inleiding}

Depreciatie van menselijk kapitaal is een belangrijk onderwerp voor een kenniseconomie zoals de Nederlandse. In dit hoofdstuk bespreken wij de literatuur aan de hand van een typologie van de verschillende oorzaken van "scholingsveroudering". Daarbij volgen wij De Grip en Van Loo (2002) die, voortbouwend op Rosen (1975), een onderscheid maken tussen de "technische veroudering" en de "economische veroudering" van menselijk kapitaal. Mensen die te kampen hebben met technische veroudering van hun menselijk kapitaal produceren minder, terwijl bij economische veroudering het menselijk kapitaal zelf zijn marktwaarde verliest. Wij gaan in op de literatuur die de depreciatie gedurende de levensloop bespreekt en leggen vervolgens de focus op de depreciatie ten gevolge van twee arbeidsmarktsituaties: inactiviteit (in verband met een loopbaanonderbreking of zorgtaken) en werkloosheid.

Dit hoofdstuk is als volgt opgebouwd. In paragraaf 2.2 bespreken wij een algemeen theoretisch model van de menselijk kapitaal theorie dat handvatten biedt voor de analyse van depreciatie van menselijk kapitaal. In paragraaf 2.3 gaan wij in op de verschillende manieren waarop depreciatie van menselijk kapitaal is gemeten in empirisch onderzoek. Empirische studies naar de gevolgen van verschillende soorten van depreciatie van menselijk kapitaal komen in paragrafen 2.4 tot en met 2.7 aan bod. Paragraaf 2.8 bevat de belangrijkste conclusies uit dit literatuuroverzicht.

\subsection{Depreciatie vanuit een menselijk kapitaal model}

\section{Algemeen model}

De theorie van het menselijk kapitaal biedt een handig raamwerk om depreciatie van menselijk kapitaal te begrijpen. Volgens het model van Ben-Porath (1967) is de waarde van het menselijk kapitaal op enig moment in de tijd een functie van de waarde in de vorige periode, de depreciatie en de nieuwe investeringen in menselijk kapitaal. Het menselijk kapitaal $(K)$ van persoon $i$ in periode $t$ is dus gelijk aan het menselijk kapitaal in de vorige periode $(t-\mathrm{I})$, minus de depreciatie daarvan in de vorige periode (de 
depreciatievoet is $\lambda$ ), plus de investeringen in het menselijk kapitaal (I), bijvoorbeeld door training (met rendement $\mu$ ):

$$
K_{i t}=(1-\lambda) K_{t-1}+\mu I_{t}
$$

Het model suggereert dat de waarde van het menselijk kapitaal over de levensloop afneemt, omdat aangenomen wordt dat de depreciatievoet $(\lambda)$ positief is. Depreciatie van menselijk kapitaal kan echter (deels) worden gecompenseerd door nieuwe investeringen. Maar het is eenvoudig om met bovenstaand model te laten zien dat ook deze nieuwe investeringen weer onderhevig zullen zijn aan depreciatie. Bovendien wordt met het ouder worden de periode waarin men het menselijk kapitaal productief kan inzetten korter, waardoor er minder prikkels aanwezig zijn om te blijven investeren.

\section{Oorzaken van depreciatie}

Er zijn verschillende mogelijke oorzaken voor depreciatie van menselijk kapitaal waarbij $\lambda>0$ (De Grip en Van Loo, 2002). Ten eerste, kan er sprake zijn van technische veroudering van menselijk kapitaal, waarbij de productiecapaciteit van mensen afneemt. Ten tweede kan er sprake zijn van economische veroudering van menselijk kapitaal waarbij het niet om veranderingen in de capaciteiten van mensen gaat, maar om een afname van de marktwaarde van iemands capaciteiten als gevolg van veranderingen die zich in de economie voordoen. Ten derde kan de sprake zijn van 'organisational forgetting'. Het gaat hier om het spiegelbeeld van Arrow's (1962) 'learning by doing' en verwijst naar de kennis die er voor bedrijven verloren gaat wanneer de competenties van hun personeel afnemen, of wanneer werknemers met bedrijfsspecifieke kennis de organisatie verlaten. Omdat wij hier de focus leggen op depreciatie van menselijk kapitaal op het individueel niveau, komen wij op deze laatste vorm van depreciatie in dit rapport niet meer terug.

Bij technische veroudering wordt een onderscheid gemaakt tussen de volgende twee vormen:

- slijtage als gevolg van het natuurlijk ouderwordingsproces, letsel of ziekte;

- atrofie vanwege het onvoldoende gebruiken van iemands competenties, bijvoorbeeld als gevolg van inactiviteit.

Slijtage leidt er in veel gevallen toe dat werkenden hun huidige functie niet langer adequaat kunnen uitoefenen. Atrofie treedt vooral op wanneer mensen vanwege werkloosheid of zorgtaken hun vak langere tijd niet uitoefenen (Mincer en Polacheck, I974; Mincer en Ofek, 1982). De kennis en vaardigheden die men eerder heeft verworven nemen daardoor af. Atrofie kan zich ook voordoen bij werkenden die lange tijd een functie vervullen waarin ze slechts een beperkt deel van hun competenties gebruiken, bijvoorbeeld omdat zij een hogere opleiding hebben dan nodig is voor het werk dat zij doen, of omdat ze slechts enkele specifieke taken verrichten (De Grip e.a., 2008). 
Bij economische veroudering kan een onderscheid worden gemaakt tussen de volgende twee vormen:

- functie-inhoudelijke veroudering vanwege technologische vernieuwingen en organisatorische veranderingen, waardoor de competenties van werknemers niet meer toereikend zijn om hun functie of beroep te kunnen blijven uitoefenen;

- sector- en bedrijfspecifieke veroudering vanwege reorganisaties of bedrijfssluitingen waardoor sector- en bedrijfspecifieke kennis verloren gaat, of veranderingen in de beroepenstructuur binnen sectoren (samengaand met een verminderde vraag naar bepaalde competenties).

Functie-inhoudelijke veroudering van menselijk kapitaal doet zich voor als de voor iemands functie vereiste competenties veranderen door het gebruik van nieuwe technologieën en de mede daaraan gerelateerde organisatorische veranderingen (zie bijvoorbeeld Neuman en Weiss, 1995). Weinberg (2002) laat zien dat de competenties van middelbaar opgeleiden (high school) vaak overgedragen kunnen worden van oude naar nieuwe technologieën. Daarentegen kampen oudere hoger opgeleiden (college) met competentieveroudering bij de introductie van nieuwe technologieën.

De economische veroudering van menselijk kapitaal kan ook het gevolg zijn van de ontwikkelingen op de arbeidsmarkt. Dit is het geval als de vraag op een bepaald segment van de arbeidsmarkt sterk krimpt. Immers, als bepaalde beroepen verdwijnen dan verliezen de voor deze functies vereiste kwalificaties hun waarde (zie bijvoorbeeld Kletzer, 1998). Ten slotte kan er sprake zijn van depreciatie van bedrijfsspecifiek menselijk kapitaal wanneer ontslagwerklozen door bedrijfssluiting of reorganisaties van het bedrijf waarin ze werkzaam waren, hun baan verliezen (Van Gaalen en Van Rooijen, 2009). Wanneer men dan weer elders werk vindt gaat het bedrijfsspecifieke menselijk kapitaal verloren (zie bijvoorbeeld Carrington, I993).

Deze vormen van depreciatie worden in tabel 2.I samengevat. Hoewel deze verschillende vormen van depreciatie conceptueel kunnen worden gescheiden, is het in empirisch onderzoek niet eenvoudig om ze van elkaar te scheiden. Zo kan de depreciatie van het menselijk kapitaal van iemand die lange tijd werkloos is het gevolg zijn van atrofie (doordat competenties niet worden benut), slijtage (doordat iemand tijdens een periode van inactiviteit ook ouder wordt), of het gevolg zijn van sector- bedrijfsspecifieke veroudering (wanneer iemands sector- of bedrijfsspecifieke kennis zijn waarde verliest). 
Tabel 2.1

Conceptueel onderscheid tussen soorten depreciatie van menselijk kapitaal

Soort depreciatie: $\quad$ Depreciatie door:

Technische veroudering

Slijtage Natuurlijk proces van ouder worden, gevolg van letsel of ziekte

Atrofie Niet gebruik of ondermatig gebruik van competenties

\begin{tabular}{|c|c|}
\hline Functie-inhoudelijk veroudering & $\begin{array}{l}\text { Technologische veranderingen vragen om nieuwe } \\
\text { competenties }\end{array}$ \\
\hline Sector- en bedrijfsspecifieke veroudering & $\begin{array}{l}\text { Verminderde vraag naar competenties, verlies van specifiek } \\
\text { menselijk kapitaal }\end{array}$ \\
\hline
\end{tabular}

Later in dit hoofdstuk komen wij uitgebreid terug op deze vormen van depreciatie en evidentie uit de empirische literatuur. In het empirische gedeelte van dit onderzoek staan de volgende drie vormen van depreciatie centraal:

- technische veroudering als gevolg van slijtage:

depreciatie over de levensloop (bij het ouder worden);

- technische veroudering als gevolg van atrofie:

depreciatie door tijdelijke periodes van inactiviteit en door werk onder eigen niveau;

- sector- en bedrijfsspecifieke veroudering:

depreciatie als gevolg van bedrijfssluiting (faillissement of massa ontslag).

Functie-inhoudelijk veroudering - veroudering van competenties door technologische veranderingen - valt buiten de vraagstelling en zal om die reden in het empirisch gedeelte van het onderzoek niet aan bod komen.

\section{Depreciatie van menselijk kapitaal tijdens loopbaanonderbrekingen}

De depreciatie van menselijk kapitaal die optreedt volgens vergelijking (I) kan zoals gezegd het gevolg zijn van technische veroudering en/of economische veroudering van menselijk kapitaal. Daarbij kunnen vooral loopbaanonderbrekingen voor depreciatie van menselijk kapitaal zorgen. In de psychologische literatuur wordt dit aangeduid als de 'use it or lose it' hypothese (Hultsch e.a., 1999): wanneer competenties en vaardigheden niet worden benut gaan deze (deels) verloren. Om dit te onderzoeken kan gebruik gemaakt worde van het model van depreciatie van menselijk kapitaal, zoals dat is geïntroduceerd door Mincer en Polachek (1974) en nader uitgewerkt door Mincer en Ofek (1982).

Het model van Mincer en Polachek (1974) maakt het mogelijk om het effect van loopbaanonderbrekingen (bijvoorbeeld als gevolg van inactiviteit of werkloosheid) op het menselijk kapitaal te kwantificeren. Deze effecten kunnen worden geïnterpreteerd als 
de mate van depreciatie van iemands menselijk kapitaal. De uitwerking door Mincer en Ofek (1982) maakt onderscheid tussen het korte-termijn en het lange-termijn effect van depreciatie, wanneer werknemers door herintrede op de arbeidsmarkt de mogelijkheid hebben gehad om het initieel effect van de onderbreking te repareren door het weer 'opfrissen' van hun kennis en vaardigheden in de nieuwe functie. ${ }^{2}$

Bezien vanuit de menselijk kapitaal theorie is de relatieve depreciatie van menselijk kapitaal de oorzaak van de lagere baankans en het lagere loon van werkenden na een periode van inactiviteit (Pissarides, 1992). Niet alleen doen werklozen tijdens de periode van werkloosheid geen werkervaring op (er wordt dus geen menselijk kapitaal opgebouwd), ook is de bedrijfsspecifieke kennis die iemand vóór de onderbreking door werkloosheid heeft opgedaan veelal onbruikbaar in de nieuwe baan. Hier is sprake van depreciatie: het menselijk kapitaal is minder waard geworden. Uit de empirische studies naar deze 'human capital hypothese' komt naar voren dat kennis en vaardigheden afnemen tijdens een periode van niet-werkzaamheid, in het bijzonder tijdens werkloosheid (Edin en Gustavson, 2008) en de zorg voor kinderen (Albrechts e.a., 1999).

De signaleringstheorie, stelt echter dat het niet zozeer gaat om depreciatie van kennis en vaardigheden, maar eerder om de signaalfunctie die uitgaat van werkloosheid en andere soorten van inactiviteit (Albrechts e.a., 1999). Zo kunnen werkgevers het feit dat werknemers zich tijdelijk terugtrekken uit betaalde arbeid interpreteren zien als een teken van gebrekkige betrokkenheid, waardoor zij een lager loon zullen bieden. Omdat de kans op werkloosheid selectief is, zijn het vooral de minst productieve werknemers die kans hebben om werkloos te worden. Potentiële nieuwe werkgevers herkennen dit signaal en zullen deze werknemers een lager loon bieden dan werknemers met evenveel ervaring die niet werkloos zijn geweest. Daarbij moet wel opgemerkt worden dat studies veelal laten zien dat werklozen deze loonachterstand voor een deel weer inlopen (zie paragraaf 2.5 en 2.7). Dit effect van werkloosheid - ook wel het 'scar effect' van werkloosheid genoemd (Gangl, 2006) - wijst er op dat werkgevers zich bij het in dienst nemen van een werkloze indekken tegen de risico's. Als ze na enige tijd betere informatie hebben over de productiviteit van hun nieuwe medewerker, dan zijn ze bereid een passend loon aan te bieden.

In empirisch onderzoek is het van belang om de signaalfunctie van werkloosheid te scheiden van depreciatie van menselijk kapitaal. Dit kan door de onderzoeksdesign zorgvuldig te kiezen of door rekening te houden met mogelijke selectie-effecten van loopbaanonderbrekingen. Om het depreciatie effect van werkloosheid te kunnen vaststellen maken sommige studies bijvoorbeeld gebruik van natuurlijke experimenten die kunnen ontstaan bij veranderingen in de ww-regelingen (Mooi-Reçi, 2008). Andere studies maken gebruik van 'matching' technieken of van de 'control function'

2. Het verschil tussen het lange-termijn en korte-termijn effect zou echter ook verklaard kunnen worden door het afnemende belang van het 'signaling' effect als iemand na een loopbaanonderbreking weer enige tijd in de nieuwe functie werkzaam is. 
aanpak (Schils e.a., 2006). ${ }^{3}$ Een aantal studies lijkt bewijs voor deze signaalhypothese te vinden doordat de omvang van de loondaling in de nieuwe baan samenhangt met de reden voor werkloosheid: mensen die werkloos zijn geworden door een faillissement ervaren een minder sterke loondaling dan mensen die ontslagen zijn wegens disfunctioneren (zie, bijvoorbeeld, Gibbons en Katz, I99I).

\subsection{Maatstaven voor depreciatie van menselijk kapitaal}

Het meten van menselijk kapitaal is niet eenvoudig (Borghans e.a., 200I). Het is evenmin eenvoudig om een maatstaf te vinden die als een vanzelfsprekende indicator voor depreciatie van menselijk kapitaal gezien kan worden. Dit komt doordat depreciatie van menselijk kapitaal zich op verschillende fronten kan manifesteren: het kan resulteren in een verminderde participatiekans of een lager loon, maar ook in een lager cognitief vermogen of problemen bij het vervullen van de eigen functie op het werk. In de review studie van De Grip en Van Loo (2002) wordt ingegaan op de verschillende manieren waarop depreciatie van menselijk kapitaal in de empirische literatuur wordt gemeten. Voortbouwend op deze indeling maken we hier een onderscheid tussen (I) objectieve en subjectieve methoden en (2) directe en indirecte methoden:

- Bij een objectieve methode gaat het om het vaststellen van de ontwikkeling in menselijk kapitaal aan de hand van objectieve meetbare instrumenten.

- Bij een subjectieve methode wordt de ontwikkeling van het menselijk kapitaal bepaald aan de hand van de beoordeling door mensen zelf.

- $\mathrm{Bij}$ een directe methode wordt de ontwikkeling van het menselijk getest (bijvoorbeeld door cognitietesten) dan wel vastgesteld aan de hand van maatstaven die rechtsreeks samenhangen met het menselijk kapitaal (bijvoorbeeld de individuele productiviteit).

- Bij een indirecte methode wordt de ontwikkeling in het menselijk kapitaal vastgesteld aan de hand van maatstaven die slechts deels samenhangen met het menselijk kapitaal (bijvoorbeeld het loon of de participatiekans).

Tabel 2.2 bevat een overzicht van de verschillende wijzen waarop depreciatie van menselijk kapitaal gemeten kan worden.

3. Bij 'matching' worden werklozen aan de hand van hun achtergrondkenmerken 'gekoppeld'aan niet werklozen om zodoende de verschillen in participatiekans of loon tussen de twee groepen zo zuiver mogelijk te kunnen schatten. Bij de 'control function' wordt aan de hand van econometrische technieken gecontroleerd voor het probleem van zelfselectie. 
Tabel 2.2

Conceptueel onderscheid in de meting van depreciatie van menselijk kapitaal

\begin{tabular}{lll} 
& Direct & Indirect \\
\hline Objectief & & \\
& - Testscores & - Loon \\
Subjectief & - Individuele productiviteit & - Participatiekans \\
& - Eigen inschatting & - Eigen inschatting kansen op \\
& kennisontwikkeling & arbeidsmarkt
\end{tabular}

\section{Objectieve methode}

Het hanteren van cognitieve en andere testen is een objectieve manier om het menselijk kapitaal direct te meten. Hetzelfde geldt voor individuele maatstaven voor fysieke productiviteit. Echter, iemands individuele productiviteit is in empirisch onderzoek meestal moeilijk vast te stellen. Het meten van de waarde van het menselijk kapitaal aan de hand van cognitieve testen wordt nu nog niet veel toegepast, maar is sterk in opkomst in de literatuur (zie bijvoorbeeld De Grip e.a., 2008). De methode heeft een sterke impuls gekregen dankzij persoonsenquêtes zoals de International Adult Literacy Survey (IALS) van de OESO (die in hoofdstuk 3 wordt gebruikt) en het Programme for International Student Assessment (PISA). ${ }^{4}$ Leuven e.a. (2004) laten zien dat testen rond geletterdheid in IALS waardevol zijn voor economische analyses en wellicht een betere maatstaf zijn voor de waarde van het menselijk kapitaal van werkenden dan het opleidingsniveau.

Het loon en de participatiekans zijn voorbeelden van veel gebruikte indicatoren voor het vaststellen van de depreciatievoet van menselijk kapitaal in paneldata analyses. In de eerder aangehaalde studie van Mincer en Ofek (1982), worden bijvoorbeeld de korte en lange termijn gevolgen van atrofie als gevolg van loopbaanonderbrekingen voor het loon van werkenden berekend. Aan de hand van Amerikaanse data uit de National Longitudinal Survey laten de auteurs zien dat de korte-termijn gevolgen van loopbaanonderbrekingen groot zijn, maar dat investeringen in menselijk kapitaal na de onderbreking ervoor zorgen dat het effect op het loon snel kleiner wordt. Van Loo e.a. (200I) gebruiken de uitstroom uit betaalde arbeid (naar werkloosheid of inactiviteit) als een indicator voor depreciatie van menselijk kapitaal.

Het loon en de participatiekans als maatstaf voor de waarde van het menselijk kapitaal rekenen wij tot de objectieve en indirecte methode. Loon en participatiekans zijn inderdaad manifestaties van de waarde van het menselijk kapitaal, maar een belangrijk probleem daarbij is dat het loon in een land als Nederland betrekkelijk inflexibel is en daarom slechts in beperkte mate de productiviteit van werknemers weerspiegelt. Denk bijvoorbeeld aan in CAOs afgesproken periodieke loonstijgingen die niet gekoppeld zijn aan de werkelijke ontwikkeling van de individuele productiviteit, of de beneden-

4. De PISA data maken het bijvoorbeeld mogelijk om het menselijk kapitaal en het leervermogen van I5 jarigen in de verschillende OESO landen in kaart te brengen. 
waartse starheid van het loon van oudere werknemers die te kampen hebben met een veroudering van hun menselijk kapitaal. Het loon als maatstaf voor de waarde van het menselijk kapitaal is daarom in het bijzonder problematisch voor werknemers op hogere leeftijd (Euwals e.a., 2009).

\section{Subjectieve methoden}

Subjectieve methoden worden ook vaak gebruikt om depreciatie van menselijk kapitaal in beeld te brengen. Daarbij valt op te merken dat het vooral gaat om directe subjectieve methoden in de vorm van een eigen inschatting van iemands kennisontwikkeling en minder vaak om indirecte subjectieve methoden, zoals een eigen inschatting van iemands kansen op arbeidsmarkt. Een voorbeeld van de eerst genoemde subjectieve methode is de studie van Allen en De Grip (2007) die zich richt op het verklaren van de vroegtijdige arbeidsmarktuittrede van oudere arbeidskrachten. $\mathrm{Zij}$ laten zien dat de perceptie van depreciatie van menselijk kapitaal er niet toe leidt dat werknemers een grotere kans lopen op het verlaten van de arbeidsmarkt. Dit wordt door de auteurs verklaard uit het feit dat werknemers die aangeven dat hun menselijk deprecieert meer aan scholing doen. Blechinger en Pfeiffer (2000) gebruiken een subjectieve vraag naar de hoeveelheid in het leerlingwezen geleerde beroepsspecifieke kennis die nog bruikbaar is in iemands huidige baan. Aan de hand van data voor Duitsland laten zij zien dat deze subjectieve informatie toegevoegde waarde heeft in een loonvergelijking à la Mincer.

Een belangrijk nadeel van subjectieve methoden is dat het alleen depreciatie van menselijk kapitaal meet die mensen zelf percipiëren. Indien werkenden niet in staat zijn om de ontwikkeling van hun eigen competenties zelf te waarderen, dan zijn subjectieve methoden van weinig nut. Thijssen en Walter (2006) geeft aan dat er daarbij zelfs sprake kan zijn van een "perspectivische veroudering" van menselijk kapitaal, wanneer mensen een verouderde visie hebben op de voor hun functie vereiste competenties. Daar staat tegenover dat de subjectieve methode wellicht beter is wanneer een daling van de waarde van het menselijk kapitaal - door rigiditeit op de arbeidsmarkt (bijvoorbeeld als gevolg van CAO afspraken of andere instituties) - zich niet gelijk vertaalt in een lager loon of een slechtere participatiekans.

\subsection{Empirische studies naar slijtage van menselijk kapitaal}

Volgens Rosen (1975) ontstaat depreciatie door slijtage omdat de manier waarop werkenden hun kennis succesvol in productieve vaardigheden weten om te zetten vermindert naarmate men ouder wordt. Borghans e.a. (2009) gebruiken een subjectieve inschatting van de eigen kennisontwikkeling onder respondenten van het Nederlandse Leven Lang Leren Enquête om te laten zien dat de kennisontwikkeling negatief gecorreleerd is aan de leeftijd. Van den Berg e.a. (20Io) maken gebruik van cognitieve testscores onder respondenten van de Longitudinal Aging Study Amsterdam. 
De studie laat zien dat iemands cognitief vermogen negatief wordt beïnvloedt door plotselinge gezondheidsproblemen (zoals, bijvoorbeeld, een hartaanval) en het verlies van partner of (klein)kinderen. De auteurs laten bovendien zien dat deze gevolgen nadeliger zijn voor mensen die ten tijde van een economische recessie geboren zijn dan voor mensen die ten tijde van een gunstige economische situatie. Dit duidt er op dat averechtse economische omstandigheden bij de geboorte een nadelig effect hebben op het herstel na ziekte op oudere leeftijd. Van Loo e.a. (200I) laten op basis van Nederlandse data van het OSA-Arbeidsaanbodpanel zien dat het risico van arbeidsmarktuitval groter is voor werkenden in zwaar fysiek en psychische beroepen.

\subsection{Empirische studies naar atrofie van menselijk kapitaal}

Atrofie kan het gevolg zijn van I) het niet gebruiken van het eigen menselijk kapitaal tijdens perioden van inactiviteit of werkloosheid, en 2) het onvoldoende gebruiken van het eigen menselijk kapitaal van werkenden. Depreciatie door atrofie wordt vaak, maar niet altijd (zie bijvoorbeeld het recent gepubliceerd onderzoek van Edin en Gustavson, 2008), onderzocht op basis van de loonontwikkeling en de participatiekans van mensen van mensen. In deze paragraaf bespreken wij een aantal studies waarin gebruik wordt gemaakt van deze objectieve indirecte methoden.

\section{Atrofie door inactiviteit}

Een van de belangrijkste studies rond atrofie van menselijk kapitaal als gevolg van inactiviteit is de studie van Mincer en Ofek (1982). De auteurs laten met Amerikaanse data zien dat loopbaanonderbrekingen nadelig zijn voor iemands loonontwikkeling, en dat het nadelig effect van deze interrupties sterker zijn naarmate ze langer duren. Mincer en Ofek laten echter ook zien dat het initieel effect van een loopbaaninterruptie op het loon groot is, maar dat dit effect na verloop van tijd kleiner wordt. Een mogelijke verklaring hiervoor is dat mensen weer investeren in hun menselijk kapitaal na de interruptie en het initiële negatieve effect op het loon weer enigszins goed weten te maken. ${ }^{5}$ Mincer en Polacheck (1978) zijn de eerste auteurs die de beroepsspecifieke depreciatie van menselijk kapitaal berekenen. Zij vinden dat de depreciatievoet van menselijk kapitaal groter is in hooggekwalificeerde beroepen. Dit zou kunnen verklaren waarom vrouwen dergelijke beroepen mijden (Mincer, I98I). Ook Albrechts e.a. (1999) laten aan de hand van Zweedse data zien dat een periode van inactiviteit nadelige consequenties heeft voor het loon van mannen (maar niet voor het loon van vrouwen).

In een onderzoek op basis van het Duitse Sociaal-economische Panel (GSOEP) naar het verlies van menselijk kapitaal waarmee vrouwen kampen na een loopbaanonder-

5. Het initiële negatieve effect van inactiviteit is overigens een onderschatting van het echte effect omdat de auteurs er van uitgaan dat mensen de loopbaaninterruptie anticiperen door voor de interruptie te kiezen voor banen met een minder steil loonprofiel. 
breking, maken Görlich en De Grip (2009) een onderscheid tussen perioden van werkloosheid en perioden waarin vrouwen geen betaald werk verrichten vanwege zorgtaken. Met betrekking tot het effect van periodes van inactiviteit op depreciatie van menselijk kapitaal komen zij tot de conclusie dat de depreciatie kleiner is voor vrouwen die werkzaam zijn in vrouwenberoepen dan voor vrouwen die werkzaam zijn in mannenberoepen. Ook voor mannen in hoog gekwalificeerde beroepen vinden zij significante nadelige effecten van arbeidsmarkt interrupties in verband met de zorg voor kinderen.

Op basis van het European Community Household Panel (ECHP) laten Muffels en Fouarge (2002) zien dat patronen van volledige inactiviteit over de levensloop vooral onder vrouwen gangbaar zijn en dat inactiviteit in het ene jaar de kans op inactiviteit een jaar later significant en negatief beïnvloedt. Op diezelfde data laten Fouarge en Muffels (2008) zien dat, voor vrouwende uittreding uit betaalde arbeid in verband met de zorg voor kinderen nadelig is voor de arbeidsparticipatie later in de loopbaan. Voor vrouwen die er wel in slagen om terug te keren naar betaalde arbeid heeft de loopbaanonderbreking een blijvend lager loon tot gevolg. Fouarge e.a. (20I0) laten aan de hand van retrospectieve data voor Nederland zien dat slechts een beperkt aantal vrouwen dat zich tijdelijk uit betaalde arbeid terugtrok in verband met de zorg van kinderen 20 jaar later de weg naar de arbeidsmarkt weer heeft weten te vinden. De auteurs trekken vergelijkbare conclusies voor vrouwen in Duitsland en het Verenigd Koningrijk. De generatieverschillen zijn echter groot; jongere cohorten slagen er steeds beter in om, na een periode van inactiviteit weer terug te treden in de arbeidsmarkt. De cohortverschillen zijn sterker in Nederland dan in de twee andere landen.

Bonsang e.a. (20IO) gebruiken een directe maatstaf om het effect van uittreding op het menselijk kapitaal te kwantificeren. Zij gebruiken een geheugentest in de Amerikaanse Health and Retirement Survey (HRS) en de Europese Survey of Health and Retirement in Europe (SHARE). In de HRS en SHARE worden door de enquêteur Io korte woorden opgenoemd (bijvoorbeeld de woorden "kind", "boek", ...). Direct daarna wordt aan respondenten gevraagd om zo veel mogelijk woorden te herhalen ('immediate recall'). Later in de vragenlijst wordt dit opnieuw gevraagd, Dit meet de 'delayed recall'. Het cognitief vermogen wordt vervolgens gemeten als de optelsom van het aantal woorden dat respondent zich wisten te herinneren in beide vragen. De auteurs laten zien dat het cognitief vermogen een negatieven functie van iemands leeftijd is en dat arbeidsmarktuittrede een significant negatief causaal effect heeft op het cognitief vermogen. Het effect van de arbeidsmarktuittrede op iemands geheugenfunctie is in kwantitatieve termen groot: het komt neer op I woord minder oftewel een afname van het cognitief vermogen van IO\%. Dit effect is overigens van vergelijkbare omvang in Amerika en Europa. 


\section{Atrofie door werkloosheid}

Er is veel onderzoek verricht naar de effecten van een periode van werkloosheid op het loon dat men verdient als men weer werk vindt en het effect van werkloosheid op iemands employability. Veel onderzoek op dit terrein heeft betrekking op Amerikaanse data (zie, bijvoorbeeld, Kim en Polachek, 1994). Kenmerkend voor de literatuur op dit terrein is dat het deels gefocust is op het 'displaced worker' effect (Ruhm, I99I); het effect van werkloosheid als gevolg van massaontslag. Op deze displaced worker literatuur wordt in paragraaf 2.7 nader ingegaan.

In de studie van Albrechts e.a. (1999) wordt voor zowel Zweedse mannen als vrouwen een negatieve looneffect van werkloosheid gevonden. Vergelijkend onderzoek voor Amerika en Europa door Gangl (2006) toont aan dat werkloosheid een negatief effect heeft op het loon in een nieuwe baan. Dit effect is vooral groot bij ouderen en werknemers met een hoog loon. Tevens laat Gangl zien dat de omvang van het effect medebepaald wordt door de arbeidsmarktinstituties.

Voor Nederland laten Schils e.a. (2006) aan de hand van het OSA-Arbeidsaanbodpanel zien dat een periode van werkloosheid een nadelig effect heeft op de baankans later in de loopbaan, maar dat dit negatief effect na ongeveer zes jaar helemaal verdwijnt. Verder blijkt dat werkloosheid een blijvend negatief effect heeft op het loon later in de loopbaan: de loonachterstand ten gevolge van werkloosheid wordt nooit meer ingehaald. Het negatieve effect van werkloosheid op het loon is overigens hoger voor vrouwen dan voor mannen. Dit is dus opmerkelijk verschillend ten opzicht van het effect van inactiviteit op het loon van vrouwen: Görlich en De Grip (2009) laten zien dat dit effect kleiner is bij vrouwen. Analyses door Fouarge (2009) op basis van een koppeling tussen de Enquête Beroepsbevolking (EBB) en het Sociaal Statistisch Bestand $(S S B)$ suggereren dat de gevolgen van werkloosheid op het loon twintig jaar later nog zichtbaar zijn.

Eveneens aan de hand van het OSA-Arbeidsaanbodpanel laat Mooi-Reçi (2008) zien dat een periode van werkloosheid de kans op herhaalde werkloosheid later in de loopbaan vergroot en dat dit sterker geldt voor vrouwen dan voor mannen. Ook Mooi-Reçi vindt een blijvend negatief effect van werkloosheid op het loon later in de loopbaan. Van Klaveren en Heyma (2008) komen op basis van analyses van het SSB tot de conclusie dat de baankans na werkloosheid vooral bepaald wordt door persoonlijke kenmerken (leeftijd, etniciteit), de afstand tot de arbeidsmarkt, werkervaring en werkloosheidsduur. $\mathrm{Zij}$ vinden een significant negatief korte-termijn effect van werkloosheid op het loon. Dit effect is ook weer groter voor vrouwen dan voor mannen.

Layte e.a. (2000) maken gebruik van data voor een aantal Europese landen om een ander gevolg van werkloosheid te illustreren: werklozen stromen de arbeidsmarkt vaak weer in op een lager functieniveau dan het beroep dat zij voorheen hadden. Dit risico 
op een baan onder het eigen niveau wordt in de eerder aangehaalde studie van MooiReçi (2008) bevestigd.

Hoewel er veel economisch onderzoek bestaat naar de psychische gevolgen van werkloosheid zoals iemands geluk en welbevinden (Clarck en Oswald, I994; Clarck, e.a. 20Io), bestaan er zijn niet veel studies waar subjectieve indicatoren worden gebruikt om de depreciatie van iemands menselijk kapitaal na een periode van werkloosheid in kaart te brengen. Er zijn evenmin veel studies te vinden waar de gevolgen van werkloosheid op depreciatie van menselijk kapitaal worden vastgesteld aan de hand van objectieve en directe maatstaven. Een mogelijke oorzaak hiervan is de afwezigheid van goede data. Een voorbeeld van een dergelijke studie is de studie van Edin en Gustavson (2008). Zij maken gebruik van cognitieve testscores rond geletterdheid voor Zweden (de IALS data die in Zweden een paneldata design hebben) om de gevolgen van werkloosheid voor iemands cognitieve vaardigheden te meten. Edin en Gustavson concluderen dat periodes van werkloosheid tot een significante afname van iemands cognitieve capaciteiten leiden, hetgeen de mogelijke oorzaak is van het negatieve effect van werkloosheid op iemands loon bij herintrede.

\section{Atrofie door onvoldoende gebruik van het menselijk kapitaal door werkenden}

Het onvoldoende gebruik van menselijk kapitaal door werkenden kan te maken met het hebben van werken onder het eigen niveau; er is dan sprake van overkwalificatie of onderbenutting. Dit komt doordat de opbouw van menselijk kapitaal kan worden gezien als een bijproduct van betaalde arbeid (Rosen, 1972). Uit de Leven Lang Leren enquête van het ROA blijkt dat men inderdaad veel informeel leert tijdens het werk: ongeveer $28 \%$ van de werktijd wordt besteed aan activiteiten waarvan iemand leert. Dit leidt tot de conclusie dat $94 \%$ van de tijd die men aan leren spendeert betrekking heeft op informeel leren (Borghans e.a., 2007).

In de studie door De Grip e.a. (2008) wordt gebruik gemaakt van een objectieve en directe methode om het verlies van cognitieve competenties als gevolg van werk onder het eigen niveau te kwantificeren. Aan de hand van cognitietesten (direct en indirect geheugen, verbale vaardigheid, informatieverwerkingssnelheid en cognitieve flexibiliteit) onder een steekproef van werkenden in Limburg (Maastricht Aging Study) meten zij het verlies van cognitieve competenties wanneer mensen 6 jaar lang onder hun niveau hebben gewerkt. Zij vinden dat werk onder het eigen niveau resulteert in verlies van cognitieve capaciteiten. Bosma e.a. (2003) lieten al eerder op basis van dezelfde data zien dat laaggeschoolden hun cognitieve capaciteiten eerder verliezen wanneer zij een laag niveau van stimuli ontvangen op hun werk.

Krahn en Lowe (1998) laten op basis van de IALS data zien dat de geletterdheid van werknemers sneller afneemt met de baanduur wanneer zij werkzaam zijn in banen die een laag niveau van geletterdheid vereisen. Arthur e.a. (1998) laten aan de hand van een meta-analyse van de psychologische literatuur zien dat depreciatie van vaardigheden 
sneller verloopt wanneer deze vaardigheden onderbenut zijn. In een studie op basis van het OSA-Arbeidsaanbodpanel van Allen en De Grip (2007) blijkt dat werknemers die te lang (meer dan 19 jaar) in eenzelfde baan blijven hangen te kampen krijgen met ervaringsconcentratie: zij hebben te veel specifiek menselijk kapitaal opgebouwd waardoor zij niet meer employable zijn bij veranderingen in de vereiste competenties en daardoor vroegtijdig de arbeidsmarkt moeten verlaten.

Bij deeltijdarbeid kan ook sprake zijn van een niet optimale benutting van menselijk kapitaal waardoor depreciatie kan ontstaan. Echter, bij deeltijdarbeid is het aannemelijker dat er sprake is van een vertraagde opbouw van menselijk kapitaal dan dat er depreciatie optreedt. In termen van model (I) is bij deeltijdarbeid waarschijnlijk sprake van minder investeringen in menselijk kapitaal - bijvoorbeeld minder 'learning by doing' - en dus een kleine $I$, en mogelijk ook kleine opbrengsten van dergelijke investeringen $(\mu)$, maar het is niet evident dat depreciatie $(\lambda)$ optreedt. Bovendien is bij deeltijdarbeid, in Nederland althans, doorgaans sprake van een vrije keuze om betaalde arbeid te combineren met zorgtaken waardoor men bewust kiest voor een minder veeleisende baan. Hoe dan ook, periodes van deeltijdarbeid blijken nadelig voor de verdere carrièreontwikkeling. Op basis van de ECHP komen Fouarge en Muffels (2008) tot de conclusie dat werknemers die in deeltijd werken een significante lagere kans maken op een sucesvolle overgang naar een voltijdsbaan een jaar later. Hoewel dit negatief effect van werk in deeltijd met de tijd kleiner wordt, blijft het ook na 3 en 5 jaar significant. Op basis van het Sociaal-Economisch Panel (SEP) van het CBS concluderen Fouarge en Muffels (2009) dat het werken in deeltijd nadelig is voor het loon van Nederlandse vrouwen (maar niet voor dat van mannen). Dit geldt ook na een geslaagde transitie naar een voltijdsbaan. Román e.a. (2004) laten aan de hand van het SEP ook zien dat werkenden met een deeltijd ervaring een grotere kans hebben om in een baan te werken met een lager functieniveau.

\section{Heterogene effecten}

De effecten van werkloosheid en inactiviteit op baankans en loon blijken verschillend naar geslacht, opleidingsniveau, leeftijd en bedrijfssector. Albrechts e.a. (I999) laten zien dat inactiviteit in verband met de zorg voor kinderen in Zweden negatief uitpakt voor mannen maar niet voor vrouwen, terwijl werkloosheid een negatief effect heeft voor zowel mannen als vrouwen. Een vergelijkbare studie voor Duitsland door Beblo en Wolf (2002) laat daarentegen zien dat de gevolgen van inactiviteit sterker zijn voor vrouwen, hetgeen het belang van de institutionele context illustreert. Onderzoek van Buligescu e.a. (2009) laat echter zien dat het negatief effect van de zorg voor kinderen op het loon van Duitse vrouwen niet blijvend is. Edin en Gustavson (2008) laten voor Zweden zien dat het effect van werkloosheid op depreciatie van kennis het sterkst is voor de laagst opgeleiden en dat de depreciatie toeneemt met de duur van de werkloosheid. Schils e.a. (2006) laten voor Nederland zien dat de gevolgen van werkloosheid sterker zijn voor oudere dan voor jongere werknemers. Ook zijn de 
gevolgen sterker voor werknemers in de publieke sector dan voor werknemers in de private sector.

\subsection{Functie-inhoudelijke veroudering}

Technologische ontwikkelingen kunnen van invloed zijn op de omvang van functieinhoudelijke veroudering doordat I) nieuwe technologieën de depreciatie kunnen versnellen, en 2) doordat ervaren werknemers die veel kennis hebben geaccumuleerd die betrekking heeft op de oude technologie hun menselijk kapitaal verliezen op het moment dat ze over moeten stappen naar nieuwe technologieën (Weinberg, 2002). Neuman en Weiss (1995) kijken naar de loon-ervaringsprofielen en vinden dat vooral hoog opgeleide mannen in high-tech sectoren te kampen hebben met depreciatie van hun menselijk kapitaal. Weinberg (2002) laat in zijn analyse echter ook zien dat nieuwe technologieën de competenties van werknemers goed kunnen aanvullen: ervaring met een oude technologie kan in sommige gevallen juist helpen bij het omgaan met een nieuwe technologie.

Bartel en Sicherman (1993) onderzoeken het effect van technologische verandering op de employability van oudere werknemers (gemeten aan de kans op vervroegd uittreden) in de VS. Zij laten zien dat alleen een onverwachte technologische verandering nadelig is voor de arbeidsparticipatie van oudere werknemers. Bij continue technologische veranderingen is er zelfs sprake van een positief effect op de arbeidsparticipatie van oudere werknemers. Friedberg (2003) laat aan de hand van data voor de VS zien dat oudere werknemers die een computer op hun werk gebruiken langer door blijven werken. Dit geldt ook na correctie voor endogeniteit van computer gebruik. Bevindingen door Fouarge en Schils (2009) op basis van de ECHP suggereren ook dat oudere werknemers die in training investeren langer blijven werken.

In een studie onder Franse bedrijven onderzoeken Aubert e.a. (2006) het effect van nieuwe technologieën en organisatieveranderingen op de leeftijdsamenstelling van het personeelsbestand. $\mathrm{Zij}$ vinden dat de loonsom voor oudere werknemers kleiner is in sterk innovatieve bedrijven. Door middel van analyses van de in- en uitstroom van werknemers laten zij ook zien dat oudere werknemers een kleinere kans hebben om aangenomen te worden in bedrijven waar sprake is van veel technologische vernieuwingen. In bedrijven waar organisatorische veranderingen plaatsvinden, hebben oudere werknemers juist een grotere kans om het bedrijf te verlaten. Deze bevindingen zijn in lijn met de hypothese van depreciatie van menselijk kapitaal door technische en organisatorische veranderingen van het productieproces.

McDowell (1982) meet depreciatie van menselijk kapitaal in 7 vakgebieden door middel van de mate waarin er artikelen worden geciteerd die ouder zijn dan 5 jaar. Hij komt tot de conclusie dat menselijk kapitaal sneller deprecieert in vakgebieden als natuurkunde en chemie dan in de geesteswetenschappen, waar veel vaker oudere 
publicaties worden geciteerd. Dit verschil in de snelheid van depreciatie van menselijk kapitaal verklaart volgens McDowell ook de hardnekkige verschillen in de studiekeuze van mannen en vrouwen. Het feit dat veel vrouwen er bij hun studiekeuze op anticiperen dat zij hun loopbaan mogelijk gaan onderbreken wanneer ze kinderen krijgen, makkt het riskant om een bèta studie te kiezen, vanwege de snelle depreciatie van menselijk kapitaal in de exacte vakken.

\subsection{Sector- en bedrijfsspecifieke veroudering}

Sector- en bedrijfsspecifieke veroudering van menselijk kapitaal heeft te maken met veranderingen in de structuur van de werkgelegenheid en het sluiten van bedrijven waardoor het sector- en bedrijfsspecifieke menselijk kapitaal - waardeloos wordt. Van Loo e.a. (200I) laten zien dat veranderingen in de sectorstructuur van de werkgelegenheid in Nederland geen invloed hebben op depreciatie van menselijk kapitaal. De toenemende vraag naar hooggekwalificeerde arbeid leidt echter voor laaggeschoolden tot een vergrootte kans op uitstroom uit betaalde arbeid. Van Loo e.a. laten ook zien dat arbeidsmobiliteit tot gevolg heeft dat de bedrijfsspecifieke kennis die mensen hebben zijn marktwaarde verliest.

Er bestaat een uitgebreide literatuur waarin specifiek ingegaan wordt op het verlies van bedrijfsspecifieke kennis als gevolg van werkloosheid door massaontslag. Deze 'displaced workers' literatuur wordt vooral gevoed door Amerikaanse studies (zie bijvoorbeeld het overzicht van Scheele e.a., 2008). Europa, en in het bijzonder Nederland, loopt op dit terrein enigszins achter. Het voordeel van deze focus op 'displaced workers' is - zo wordt in deze literatuur beargumenteerd - dat werkloosheid ten gevolge van massaontslag of faillissementen niet te wijten is aan het disfunctioneren of andere tekortkomingen van de ontslagen werknemer zelf. Een dergelijke setting maakt het dus mogelijk om het effect van werkloosheid op de waarde van iemands menselijk kapitaal te bepalen, zonder dat er een vertekening optreedt vanwege een selectie-effect (Kriechel, 20IO).

Hamermesh (1987) liet op basis van Amerikaanse data zien dat 'displaced workers' een aanzienlijk deel van hun bedrijfsspecifieke menselijk kapitaal verliezen. Dit komt tot uitdrukking in een lager loon na werkloosheid. Een belangrijk onderzoek op dit terrein is dat van Jacobson e.a. (1993). Zij gebruiken administratieve data voor de Amerikaanse staat Pennsylvania om de effecten van werkloosheid als gevolg van massaontslag te kwantificeren. Zij vinden grote effecten van een periode van werkloosheid op het loon bij herintrede; het loonverlies bedraagt maar liefst $25 \%$ van het oude loon. Daarbij is het inkomensverlies van mannen groter dan het inkomensverlies van vrouwen. Bovendien laten de auteurs ook zien dat het loon al in de vier jaar voor het massaontslag lager wordt. Hierdoor is er mogelijk al voor het massaontslag al sprake van een selectie-effect doordat de werknemers met de betere externe arbeidsmarktper- 
spectieven overstappen naar een ander bedrijf. Echter, de analyses van Hamermesh (I987) wijzen niet op een dergelijke selectie vóór het massaontslag.

Kletzer (1998) laat op basis van de Amerikaanse Current Population Survey zien dat het effect van werkloosheid op het loon afhankelijk is van de mate waarin het bedrijfsspecifieke menselijk kapitaal overgedragen kan worden van de ene naar de andere baan. Zo blijkt het inkomensverlies van werklozen die van sector veranderen groter te zijn dan die van werknemers die een nieuwe baan hebben gevonden binnen dezelfde sector. Een verklaring hiervoor is dat werknemers door deze sectorverandering hun sectorspecifieke menselijk kapitaal niet meer kunnen inzetten. Volgens het onderzoek van Neal (1995) is het inkomensverlies als gevolg van massaontslag het grootst voor werknemers met veel dienstjaren die van sector veranderen.

De analyses door Burda en Mertens (200I) laten ook een inkomensverlies na massaontslag zien in Duitsland op basis van de GSOEP en data van het Institut für Arbeitsmarkt- und Berufsforschung (IAB). De inkomensverliezen zijn hier eveneens groter voor werknemers die na ontslag van sector zijn veranderd, maar ook groter voor werknemers aan de bovenkant van de loonverdeling. Eveneens op basis van de GSOEP laat Couch (200I) zien dat werklozen als gevolg van massaontslag weliswaar een lager loon verdienen in hun nieuwe baan, maar dat de inkomensachterstand na verloop van tijd deels wordt ingehaald. Het gemeten effect op het loon in Duitsland is ongeveer vergelijkbaar met de laagste effecten die voor Amerika worden gevonden. In termen van de participatie kans laat de studie van Couch zien dat deze aanvankelijk lager is voor personen die recentelijk werkloos waren, maar dat het na een paar jaar niet meer uitmaakt of men wel of niet eerder werkloos is geweest.

Voor het Verenigd Koningrijk vinden Gregory en Jukes (200I) op basis van data van het New Earnings Survey Panel blijvende negatieve effecten van werkloosheid op het loon. Deze effecten zijn, zoals ook in ander onderzoek is aangetoond, groter voor ouderen (hoewel voor hen de kans op massaontslag kleiner is) en hoogopgeleiden. Arulampalam (200I) vindt op basis van de British Household Panel Study (BHPS) negatieve en blijvende inkomenseffecten van werkloosheid. Zij laat bovendien zien dat dit effect kleiner is voor werklozen die om bedrijfseconomische reden zijn ontslagen dan voor werklozen die om andere redenen zijn ontslagen. Meer recent is de studie van Hijzen e.a. (20I0) op basis van verschillende databronnen voor het Verenigd Koninkrijk. Hun conclusie is dat een periode van werkloosheid een negatief effect heeft op iemands loon, maar dat dit effect kleiner is voor werknemers die werkloos zijn geworden door massaontslag dan voor werklozen als gevolg van een faillissement. ${ }^{6}$ In hun studie verdwijnt het negatieve looneffect van werkloosheid na ongeveer vijf jaar.

6. Dit zou het gevolg kunnen zijn van het feit dat massaontslag ook werknemers omvat die vrijwillig het bedrijf verlaten. 
In Nederland is er minder onderzoek naar het verlies van menselijk kapitaal bij ontslagwerklozen. Abbring e.a. (2002) gebruiken enquêtegegevens uit het OSA-Arbeidsaanbodpanel en maken een vergelijking met de VS. Zij vinden voor Nederland langere werkloosheidsduren. Wel blijkt werkloosheid als gevolg van massaontslag de uitstroom naar vervroegde uittreding te stimuleren. Ook vinden ze dat in Nederland het loon in de nieuwe baan na ontslag hoger is dan het loon in de oude baan. Dit suggereert dat een vergelijking van de loongroei van ontslagen en nietontslagen werknemers economisch relevanter is dan de vergelijking van het loonniveau voor en na het ontslag. Een mogelijke verklaring voor het ontbreken van een negatief effect op het loon is dat werknemers op een massaontslag anticiperen en vooraf al op zoek gaan naar een andere baan. Verder bestaat het Nederlands onderzoek op dit terrein vooral uit analyses van de gevolgen van het faillissement van Fokker in I996 (Kriechel, 2003). Hoewel de ontslagen Fokker werknemers betrekkelijk snel na het faillissement weer een baan hebben gevonden ( $77 \%$ had na een jaar weer werk, na drie jaar was dat $85 \%$ ) zijn de geleden inkomensverliezen gevoelig: per maand van werkloosheid bedraagt het loonverlies $0,65 \%$. De participatiekans na het faillissement is kleiner voor oudere en laagopgeleide werknemers. Bovendien is het loonverlies voor oudere werknemers significant groter (Kriechel en Pfann, 2005).

Meer recent hebben de WRR en het CBS een studie gepubliceerd over massaontslag in Nederland (Scheele e.a., 2008). De studie is gebaseerd op analyses van het CBS op het Sociaal Statistisch Bestand (SSB). Massaontslag is in de studie gedefinieerd als een uitstroom van werknemers uit een bedrijf die hoger ligt dan de normale uitstroom uit het bedrijf. Geconcludeerd wordt dat tweederde van de werknemers een half jaar na ontslag weer werk heeft; 3 jaar na ontslag is dit $68 \%$. Wat het inkomen betreft concludeert de WRR opmerkelijk genoeg dat massaontslag een gunstige dynamiek tot stand weet te brengen doordat werkloosheid een positief effect op het loon heeft. Hier zou sprake kunnen zijn van heterogeniteit in het effect van werkloosheid op het loon na werkloosheid waarbij het vooral jongeren zijn die beter af worden terwijl ouderen juist terechtkomen in banen met een lager loon.

\subsection{Conclusie}

In dit hoofdstuk is er een conceptueel kader geschetst, waarbinnen verschillende oorzaken van depreciatie van menselijk kapitaal kunnen worden onderscheiden. Daarbij is er in eerste instantie een onderscheid gemakt tussen twee soorten depreciatie: technische veroudering (slijtage en atrofie) en economische veroudering (functieinhoudelijk veroudering en sector- en bedrijfsspecifieke veroudering). Daarnaast is een onderscheid gemaakt tussen de manieren waarop depreciatie gemeten kan worden. Dit onderscheid vindt plaats langs twee dimensies: objectieve versus subjectieve maatstaven en directe versus indirecte maatstaven. 
Empirisch onderzoek naar de technische veroudering van menselijk kapitaal laat zien dat periodes van inactiviteit gepaard gaan met verlies aan menselijk kapitaal. Ook werkloosheid resulteert in een waardedaling van het menselijk kapitaal. Deze waardedaling manifesteert zich zowel in een lagere participatiekans en een lager loon na herintrede, als in lagere scores op cognitieve en geheugentesten. Uit onderzoek blijkt dat het effect van inactiviteit en werkloosheid op het loon doorgaans blijvend is (de opgelopen depreciatie wordt niet meer volledig ingehaald), maar dat het effect of de participatiekans slechts tijdelijk is (na verloop van tijd zijn de effecten van werkloosheid niet meer merkbaar). Onderzoek laat ook zien dat de effecten van inactiviteit en werkloosheid heterogeen zijn: de gevonden effecten verschillen naar geslacht, leeftijd en beroep. Zo zijn bijvoorbeeld de negatieve gevolgen van werkloosheid sterker voor ouderen dan voor jongeren en de negatieve gevolgen van inactiviteit verschillend tussen mannen en vrouwen, afhankelijk van de institutionele context: in Duitsland ondervinden vrouwen een groter nadeel van inactiviteit dan mannen wat hun arbeidsmarktkansen later in de loopbaan betreft, maar in Zweden is het omgekeerde het geval.

Bij economische veroudering heeft depreciatie van menselijk kapitaal als gevolg van sector- en bedrijfsspecifieke veroudering speciale aandacht gekregen. In empirisch onderzoek is - zij het in beperkte mate - aandacht besteed aan de gevolgen van massaontslag voor de arbeidsmarktkansen en het loon na ontslag. Een kenmerk van werkloosheid door massaontslag is dat het niet de werknemer zelf aangerekend kan worden: er is doorgaans geen sprake van eigen schuld, maar van een bedrijfseconomische reden. Ondanks het feit dat er geen sprake is van eigen schuld laat onderzoek zien dat massaontslag een lager loon tot gevolg heeft. Wel is het zo dat de loonachterstand sneller wordt ingelopen dan bij 'gewone' werkloosheid. Dit duidt op het verloren gaan van bedrijfsspecifiek menselijk kapitaal dat langzamerhand in de nieuwe baan weer wordt opgebouwd. Echter, wanneer de ontslagen werknemer een baan in een andere sector vindt, is de loonachterstand groter dan bij een nieuwe baan in dezelfde sector. Dit lijkt er op te wijzen dat in dat geval ook sectorspecifiek menselijk kapitaal verloren gaat.

De verschillende soorten depreciatie kunnen empirisch gezien niet altijd goed van elkaar worden onderscheiden. Ook zijn er door databeperkingen niet altijd voorbeelden te vinden van studies die depreciatie meten langs de hier onderscheiden dimensies. Toch heeft dit hoofdstuk een overzicht geboden van het bestaande empirisch onderzoek naar depreciatie van menselijk kapitaal. Daaruit komt het beeld naar voren dat met name inactiviteit, werkloosheid en onvoldoende gebruik van menselijk kapitaal tot depreciatie van menselijk kapitaal kunnen leiden, ook al zijn de effecten niet altijd gelijk voor alle groepen werknemers. In de rest van dit rapport gaan wij in op depreciatie van menselijk kapitaal gedurende de levensloop, waarbij wij gebruik maken van directe methoden (objectieve en subjectieve directe methoden) om de waarde van het menselijk kapitaal te bepalen. Daarna gaan wij achtereenvolgens in op het effect van inactiviteit en werkloosheid als gevolg van massaontslag of een fail- 
lissement op de waarde van het menselijk kapitaal. Bij deze analyses gaan wij uit van objectieve, maar indirecte indicatoren voor het menselijk kapitaal. 



\section{Depreciatie van menselijk kapitaal over de levensloop}

\subsection{Inleiding}

Zoals uit hoofdstuk 2 is gebleken maakt het merendeel van het onderzoek naar depreciatie van menselijk kapitaal gebruik van loongegevens om de depreciatie over de levensloop in kaart te brengen. Het lijkt er op dat de directe maatstaven voor het meten van het menselijk kapitaal minder vaak gebruikt worden in empirisch onderzoek. Vermoedelijk heeft dit te maken met de beschikbaarheid van data; goede data met directe metingen van het menselijk kapitaal zijn schaars, terwijl (panel) data met loongegevens steeds beter toegankelijk worden.

Depreciatie wordt in de meeste studies dus afgeleid van leeftijd-loonprofielen. Het loon is echter slechts indirect gerelateerd aan de productiviteit van werknemers en om die reden geen optimale maatstaf voor het meten van depreciatie van menselijk kapitaal. CAOs afgesproken rond periodieke loonstijgingen die niet gekoppeld zijn aan de werkelijke ontwikkeling van de productiviteit, starheid van het loon voor aanpassingen naar beneden, impliciete afspraken tussen werkgever en werknemer voor uitgestelde betaling van hun productiviteit (ook wel aangeduid als 'backloading') en andere institutionele afspraken zorgen er voor dat het loon niet mee fluctueert met de veranderingen in de waarde van het menselijk kapitaal. Bovendien is het loon slechts waarneembaar voor werkenden waardoor het niet mogelijk is om voor de gehele bevolking depreciatie van menselijk kapitaal te berekenen.

Dit allemaal betekent niet dat het bestuderen van de loonontwikkeling geen nuttige informatie oplevert met betrekking tot de waarden van het menselijk kapitaal, maar het heeft wel een aantal beperkingen waar men zich goed bewust van moet zijn. In dit hoofdstuk volgen wij recente ontwikkelingen in de economische literatuur en stellen wij depreciatie van menselijk kapitaal vast aan de hand van directe indicatoren, zoals iemands geletterdheid en kennisontwikkeling. Directe indicatoren hebben eveneens hun beperkingen, welke in dit hoofdstuk aan bod zullen komen. Dat een directe meting van het menselijk kapitaal nuttig is en niet per se strijdig met onderzoek gebaseerd op loongegevens wordt geillustreerd door de studie van Edin en Gustavson (2008). Zij laten zien dat werkloosheid tot een significante afname van iemands 
cognitieve capaciteiten leidt. Een dergelijke afname in cognitieve capaciteiten zou het negatieve effect van werkloosheid op iemands loon bij herintrede kunnen verklaren.

Opgemerkt moet worden dat de in dit hoofdstuk besproken veranderingen in het menselijk kapitaal over de levensloop betrekking hebben op de netto verandering in het menselijk kapitaal. ${ }^{7}$ Dat wil zeggen dat de tegenovergestelde effecten van depreciatie - door arbeidsmarkt onderbrekingen - en investeringen - door training - (zie model (I) in hoofdstuk 2) op de waarden van het menselijk met de beschikbare data niet kunnen worden onderscheiden.

Dit hoofdstuk is als volgt opgebouwd. In paragraaf 3.2 geven wij een beschrijving van de in dit hoofdstuk gebruikte data. Vervolgens schetsen wij in paragraaf 3.3 de ontwikkeling in de functionele geletterdheid gedurende de levensloop. In paragraaf 3.4 bespreken we de depreciatie van menselijk kapitaal op oudere leeftijd. In paragraaf 3.5 gaan wij in op de kennisontwikkeling gedurende de levensloop. Ten slotte gaan we in paragraaf 3.6 in op de conclusies van dit hoofdstuk.

\subsection{Data}

In hoofdstuk 2 is reeds aangegeven dat depreciatie van menselijk kapitaal in de literatuur op zowel directe als indirecte wijze, en volgens zowel objectieve als subjectieve methoden gemeten wordt. De analyses in dit hoofdstuk hebben betrekking op een directe meting van de ontwikkeling van menselijk kapitaal aan de hand van zowel objectieve als subjectieve maatstaven. Er wordt gebruik gemaakt van een vijftal databestanden:

- de International Adult Literacy Survey;

- de Adult Literacy and Life Skills Survey;

- de Health and Retirement Study;

- de Survey of Health, Ageing and Retirement in Europe;

- de ROA Leven Lang Leren Enquête.

\section{Functionele geletterdheid}

Het beschikbaar komen van grootschalige surveys waarin cognitieve testen zijn afgenomen onder respondenten, maakt het mogelijk om iemands menselijk kapitaal te bepalen. In dit hoofdstuk gebruiken wij gegevens uit de International Adult Literacy Survey (IALS) en de Adult Literacy and Life Skills Survey $(A L L)$ voor Nederland (Houtkoop, 1999). Beide surveys zijn door de OESO gecoördineerde grootschalige onderzoeken, waar Nederland in heeft geparticipeerd. Het doel van beide onderzoeken was om na te gaan in hoeverre volwassenen in staat zijn om schriftelijke

7. Dit zou alleen mogelijk zijn aan de hand van panel data met gegevens rond geletterdheid en cursus participatie. Dergelijke data voor een representatieve steekproef van de Nederlandse beroepsbevolking zijn echter niet beschikbaar. 
informatie te lezen en te begrijpen. Het gaat daarbij om basisvaardigheden, ook wel iemands functionele geletterdheid genoemd. In dit OESO onderzoek zijn op twee meetmomenten (IALS in 1994 en ALL 2008) testen van functionele geletterdheid afgenomen onder een representatieve steekproef van de Nederlandse bevolking van I6 tot en met 65 jaar. De IALS en ALL data omvatten respectievelijk ongeveer 2.800 en 5.600 respondenten. ${ }^{8} \mathrm{Bij}$ de analyses is alleen gebruik gemaakt van respondenten van 20 tot en met 65 jaar.

Functionele geletterdheid wordt als volgt gedefinieerd: "Literacy is using printed and written information to function in society, to achieve one's goals, and to develop one's knowledge and potential" (Kirsch, 200I: p. 6). In de huidige kenniseconomie is functionele geletterdheid in toenemende mate van belang voor de productiviteit op de werkplek. Traditioneel wordt er een onderscheid gemaakt tussen twee vormen van functionele geletterdheid: leesvaardigheden en rekenvaardigheden. Binnen het domein van leesvaardigheden wordt door Jones (1995) een onderscheid gemaakt tussen lezen om te doen en lezen om te leren, hetgeen naar verschillende leesvaardigheden verwijst: proza- en documentengeletterdheid (Houtkoop, 1999). Naar aanleiding van dit onderscheid worden in IALS en ALL drie vormen van functionele geletterdheid gemeten:

- Prozageletterdheid is een maatstaf voor het niveau van vaardigheden die men bezit om informatie uit bijvoorbeeld kranten, boeken, tijdschriften. te lezen en te begrijpen.

- Documentengeletterdheid is een maatstaf voor het niveau van vaardigheden dat men bezit om informatie uit geconcentreerde teksten (bijvoorbeeld, sollicitatieformulier, tv gids, grafiek) te vinden en te begrijpen.

- Numerieke geletterdheid is een maatstaf voor het niveau van vaardigheden die men bezit op het gebied van rekenen en om cijfermatige informatie in bijvoorbeeld formulieren en advertenties te vinden en te begrijpen.

Proza- en documentengeletterdheid zijn in IALS en ALL op vergelijkbare wijze gemeten. De numerieke geletterdheid is echter in ALL breder gedefinieerd dan in IALS, terwijl in IALS de nadruk vooral ligt op iemands rekenvaardigheid. Met dit verschil dient rekening te worden gehouden bij de vergelijking van de gegevens rond numerieke geletterdheid uit beide surveys.

De functionele geletterdheid is gemeten op een schaal van o van 500 die geen inhoudelijke betekenis heeft. Elke punt op de schaal geeft aan dat de betreffende respondent een kans van $80 \%$ heeft om te slagen bij een taak van het betreffende moeilijkheidsniveau. Bijvoorbeeld, een respondent met een score van 250 heeft een $80 \%$ kans om te slagen bij een taak met een moeilijkheidsniveau gelijk aan 250 (en dus een kans groter dan $80 \%$ om te slagen op eenvoudigere taken). Bij het scoren van de taken is gebruik gemakt van inzichten uit de Item Response Theory en zijn taken aan de respondenten aangeboden met een oplopende moeilijkheidsgraad. Zie Murray e.a. (I997)

8. Een verantwoording van het veldwerk voor IALS is te vinden in Murray e.a. (1997). Een verantwoording van het veldwerk voor ALL is te vinden in StatCan (2002). 
voor meer detail. Omdat de enquêtetijd beperkt is en het aantal af te nemen testen groot is, is in de enquête met boekjes gewerkt waarin deelnemers telkens een deel van de testen voorgelegd hebben gekregen. Deze aanpak resulteert in vijf verschillende metingen voor elk van de drie onderscheiden vaardigheden. ${ }^{9}$

In de literatuur wordt een onderscheid gemaakt tussen 'fluid intelligence' en 'cristallized intelligence' (Cattell, 1983). Het eerste verwijst naar iemands werkgeheugen. Deze 'fluid intelligence' neemt toe tot ongeveer een jaar of 20 , om vervolgens geleidelijk af te nemen met het oplopen van de leeftijd. 'Cristallized intelligence' verwijst daarentegen naar het lange-termijn geheugen. Het neemt in het algemeen toe met de leeftijd door opbouw van ervaring (met afnemende groeivoet), bereikt een plafond om vervolgens na de leeftijd van ongeveer 70 af te nemen (Horn en Cattell, 1967). Het is echter niet geheel duidelijk welke type 'intelligence' de vragen in IALS en ALL meten (Venezky, I992), maar testen wijzen er op dat het soort vragen een groter beroep doen op 'fluid' dan op 'cristallized intelligence' (Sticht e.a., 1996).

\section{Geheugenscore}

Een andere manier om het menselijk kapitaal te meten is gebruik te maken van de in hoofdstuk 2 genoemde geheugen testscores (De Grip e.a., 2008; Bonsang e.a., 20IO; Rohwedder en Willis, 20Io). In de Amerikaanse Health and Retirement Study (HRS) en de Europese Survey of Health, Ageing and Retirement in Europe (SHARE) ${ }^{\mathrm{ro}}$ wordt het cognitief vermogen van respondenten gemeten op basis van hun directe en indirecte geheugen (zie paragraaf 2.5).

De HRS en SHARE maken het mogelijk om in te zoomen op het cognitief vermogen van ouderen. In dit hoofdstuk (paragraaf 3.4) bespreken wij de testscores van 50-90 jarigen in de VS, Nederland en de rest van Europa. ${ }^{\text {II }}$

\section{Kennisontwikkeling}

Een nadeel van de functionele geletterdheid zoals die in IALS en ALL gemeten wordt, is dat het andere vaardigheden die eveneens productief kunnen worden ingezet in het arbeidsproces (zoals, bijvoorbeeld communicatieve vaardigheden en het vermogen

9. Er wordt naar deze metingen verwezen als zijnde 'plausibele waarden'. Hoewel elke plausibele aannemelijk is, is de betrouwbaarheid daarvan geringer dan bij andere standaard testen (von Davier e.a., 2009). Voor de berekening van het gemiddelde en de variantie van de plausibele waarden wordt hier aangesloten bij de methode die de StatCan voorschrijft (StatCan, 2002). Zie bijlage I voor de details van de berekening.

Io. SHARE bevat gegevens voor I4 Europese landen, te weten Oostenrijk, België, Tsjechië, Duitsland, Denemarken, Frankrijk, Griekenland, Ierland, Italië, Nederland, Polen, Spanje, Zweden en Zwitserland.

II. Met dank aan Eric Bonsang (ROA) voor het berekenen van de in paragraaf 4.4 gepresenteerde testscores. 
om samen te werken) niet gemeten worden. ${ }^{12}$ Mede om die reden worden de analyses op basis van de IALS en ALL data aangevuld met analyses op basis van de ROA Leven Lang Leren Enquête 2004 en 2007. (zie Borghans e.a., 2006 en 2009). Deze enquêtes zijn gehouden onder respondenten van het CentERdata-panel. Dit panel heeft betrekking op een representatieve steekproef van ongeveer 2.000 huishoudens. Er respondeerden 2.375 personen van I 6 jaar en ouder in 2004 en I. 776 personen van I6 jaar en ouder in 2007 .

Hoewel de ROA Leven Lang Leren Enquête een directe maatstaf voor menselijk kapitaal bevat is deze maatstaf, in tegenstelling tot de maatstaf in IALS/ALL, niet objectief maar subjectief. Het gaat om de eigen inschatting van de kennisontwikkeling van werkenden en niet-werkenden over de levensloop (Borghans e.a., 2009). De enquêtes bevatten vragen rond de kennis en vaardigheden die nodig zijn om het werk dat men doet goed te kunnen doen. Aan respondenten is gevraagd om een inschatting te geven van de kennis en vaardigheden twee jaar voor de enquête en op het moment van de enquête. Antwoorden konden op een schaal van o tot Ioo worden gegeven waarbij IOo de situatie aangeeft: waarin iemands kennis en vaardigheden perfect aansluiten bij de kennis en vaardigheden die nodig zijn om de baan die men heeft goed uit te kunnen oefenen.

De vraag is niet alleen gesteld aan werkenden, maar ook aan niet-werkenden. Voor niet-werkenden is de vraag gesteld in de context van het soort werk dat zij het liefst zouden willen doen, hetgeen in een eerdere vraag in de vragenlijst is vastgesteld. De vraag maakt het daarom mogelijk om de kennisontwikkeling over de levensloop voor zowel werkenden als niet-werkenden in beeld te brengen.

\subsection{Geletterdheid over de levensloop}

In deze paragraaf schetsen we een beeld van de ontwikkeling van de functionele geletterdheid (proza-, document- en numerieke geletterdheid) over de levensloop. Dit doen wij op twee manieren. Ten eerste, schetsen wij een beeld van de ontwikkeling van geletterdheid bij opeenvolgende leeftijdsgroepen. Ten tweede, maken wij gebruik van het feit dat wij over twee verschillende metingen in de jaren 1994 en 2008 beschikken. Daarmee kunnen we een beeld geven van de ontwikkeling van de functionele geletterdheid bij het ouder worden van personen in een bepaald leeftijdscohort.

I2. Agarwal e.a. (2009) gebruiken data uit de HRS om het effect van cognitief vermogen op financiële beslissingen van ouderen te onderzoeken. Zij laten zien dat 'fluid intelligence' afneemt met de leeftijd, maar suggereren dat deze afname deels gecompenseerd door de stijging van ervaringskapitaal, oftewel 'crystallized intelligence'. Het is aannemelijk dat sommige algemene vaardigheden zoals probleemoplossend vermogen in IALS en ALL wel worden gemeten. 


\section{Geletterdheid naar leeftijd}

Figuur 3.I geeft een beeld van de functionele geletterdheid verbijzonderd naar leeftijd. De figuur laat zien dat prozageletterdheid en documentengeletterdheid in 2008 tussen de leeftijd van 20 tot 40 jaar op hetzelfde niveau ligt. ${ }^{13}$ Vanaf 40 jaar nemen beide soorten geletterdheid af, al wordt prozageletterdheid pas significant lager bij mensen van 50 jaar en ouder. Het beeld voor 1994 is niet veel anders, al lijkt de prozageletterdheid sterker af te nemen met de leeftijd. Ook de numerieke geletterdheid neemt af met het stijgen van de leeftijd. Echter, de depreciatie over de levensloop zet iets later in. Pas vanaf 50 jaar is numerieke geletterdheid significant lager dan bij jongeren.

\section{Figuur 3.1}

Functionele geletterdheid naar leeftijd
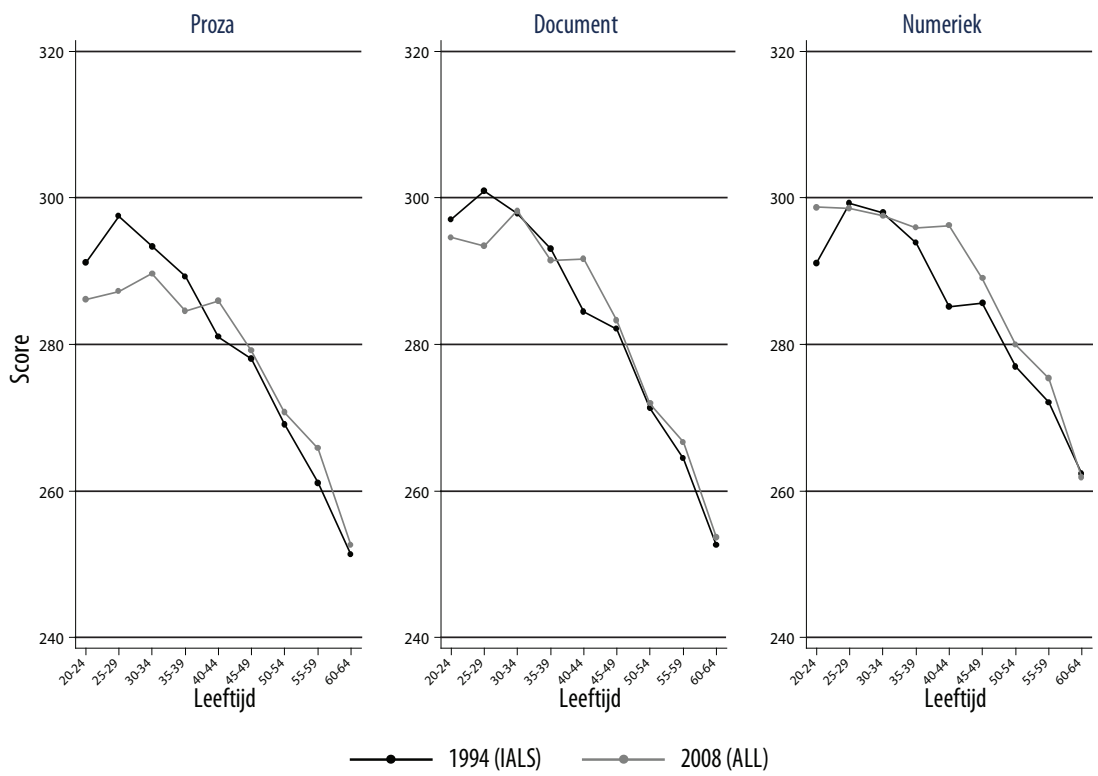

Bron: IALS, 1994; ALL, 2008

Het niveau van de prozageletterdheid verschilt niet tussen mannen en vrouwen (figuur 3.2). Ook het patroon over de levensloop is bij mannen en vrouwen hetzelfde. Voor documentgeletterdheid en numerieke geletterdheid geldt dat vrouwen iets lager scoren dan mannen, maar de afname met het oplopen van de leeftijd verschilt niet tussen beide geslachten.

13. Hoewel wij respondenten jonger dan 20 jaar niet hebben betrokken bij onze berekeningen is het interessant op te merken dat, zoals verwacht mag worden op basis van de literatuur, cognitieve vaardigheden (proza, document en numeriek) sterk toenemen tot 20 jaar. 


\section{Figuur 3.2}

Functionele geletterdheid naar leeftijd en geslacht
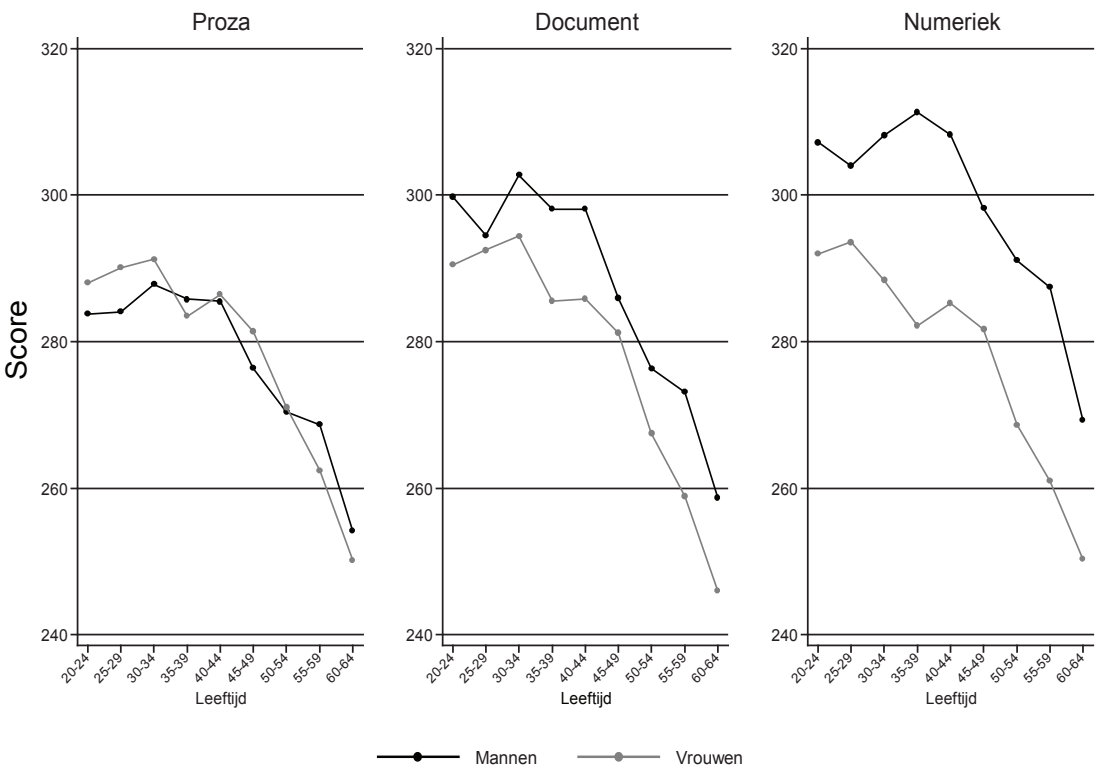

Bron: ALL, 2008

Het niveau van geletterdheid is, zoals men zou kunnen verachten, hoger naarmate het opleidingsniveau hoger is (figuur 3.3). Dit verschil naar opleidingsniveau is significant: de hoogopgeleiden (hbo of wo) hebben een hoger niveau van geletterdheid dan middelbaar opgeleiden (havo/vwo of mbo), en middelbaar opgeleiden hebben een hoger niveau van geletterdheid dan laagopgeleiden (vmbo of lager). ${ }^{\mathrm{I}}$ In absolute termen is het verschil tussen de hoger en lager opgeleiden groter voor numeriek geletterdheid. Figuur 3.3 laat zien dat de ontwikkeling in de functionele geletterdheid over de levensloop geen duidelijke verschillen laat zien naar opleidingsniveau. Anders gezegd, het verloop van de lijnen naar leeftijd is dezelfde voor alle opleidingsniveaus. Statistische testen voor het verschil in het verloop van de depreciatie over de levensloop laten geen significante effecten zien.

I4. Het niveau van functionele geletterdheid is overigens ook significant lager voor inactieven en werklozen dan voor werkenden. 


\section{Figuur 3.3}

Functionele geletterdheid naar leeftijd en opleidingsniveau
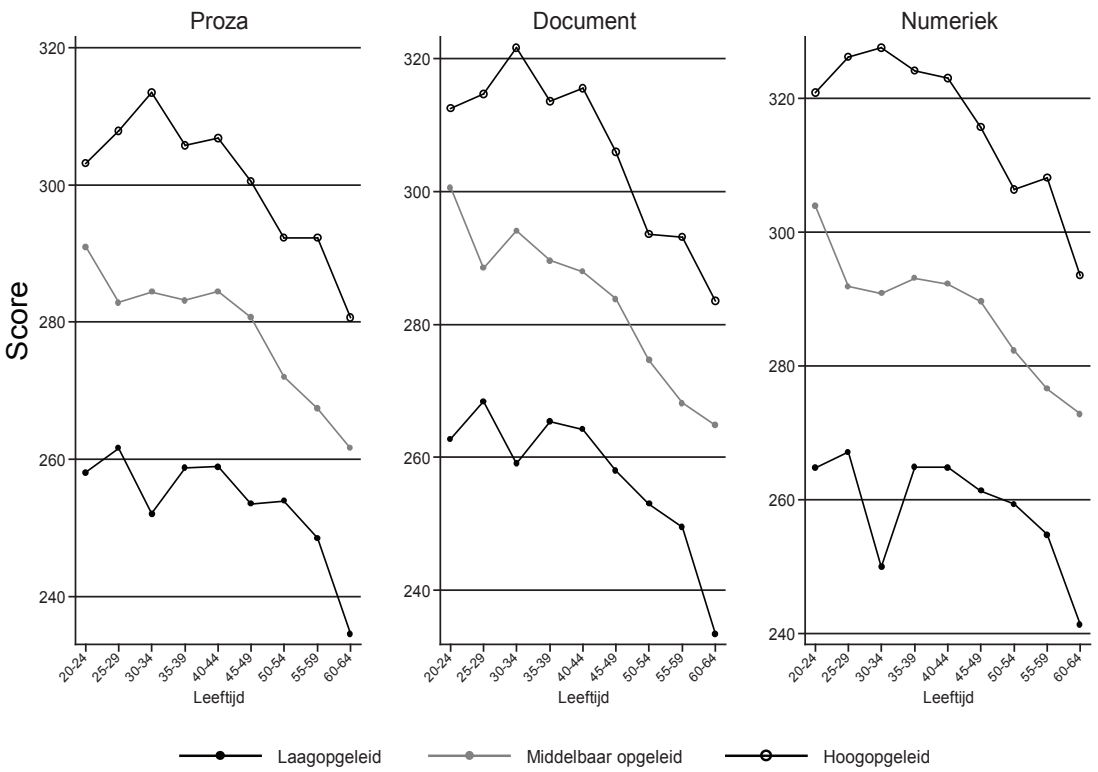

Bron: ALL, 2008

\section{Compositie-effecten}

Door compositie-effecten is het mogelijk dat het patroon van depreciatie van menselijk kapitaal zoals dat in figuur 3.I wordt gepresenteerd overschat wordt. Dit zal het geval zijn wanneer in onze data bijvoorbeeld de ouderen niet alleen qua leeftijd verschillen van de jongeren, maar ook wat qua opleidingsniveau. Om met dergelijke verschillen rekening te houden is op basis van een regressie analyse de depreciatie van de functionele geletterdheid bepaald, waarbij rekening is gehouden met de achtergrond kenmerken leeftijd, geslacht, arbeidsmarkt status, geboorteland en opleidingsniveau. De aldus verkregen geschatte waarden voor de functionele geletterdheid naar leeftijd zijn weergegeven in figuur 3.4, samen met de ruwe scores uit figuur 3.I. Het patroon van depreciatie van menselijk kapitaal blijkt minder stijl dan op basis van de ruwe scores. Dit wijst op het belang van compositie effecten. Significant lagere scores op geletterdheid worden gevonden vanaf leeftijd 45 voor prozageletterdheid en vanaf 40 jaar voor document en numerieke geletterdheid. 
Figuur 3.4

Functionele geletterdheid naar leeftijd, gecontroleerd voor achtergrond kenmerken'
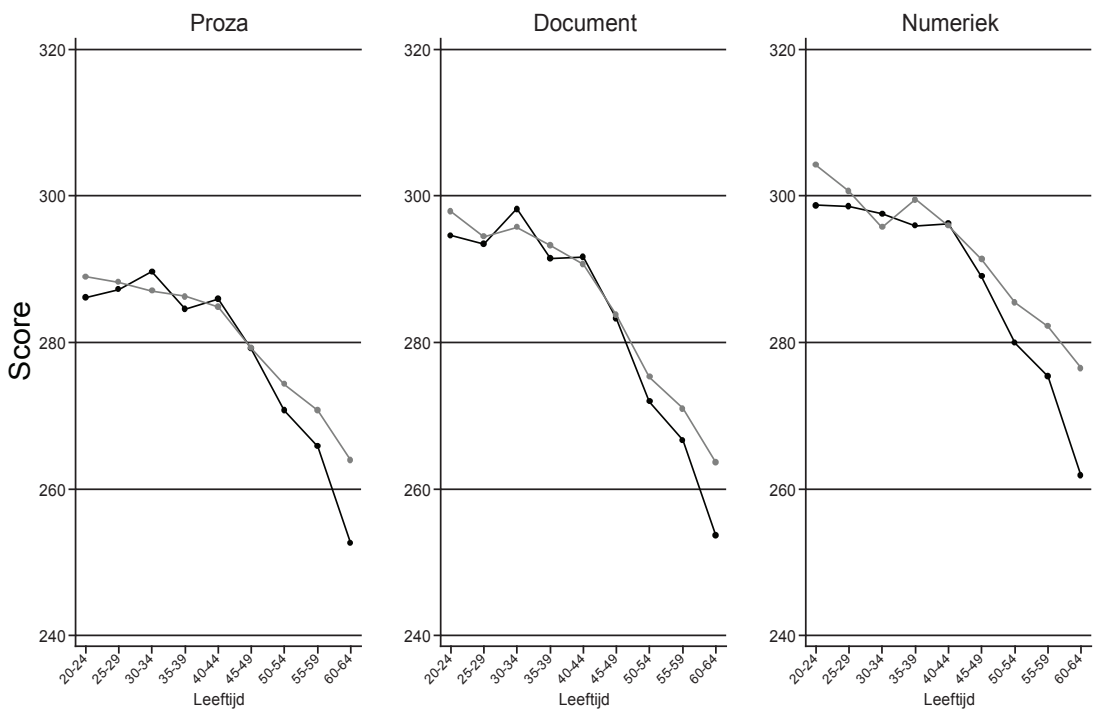

Bron: ALL, 2008

1. De zwarte lijn komt overeen met de in figuur 3.1 gepresenteerde ruwe scores voor ALL (2008). De grijze lijn is verkregen aan de hand van de voorspelde waarden voor de functionele geletterdheid op basis van een OLS schatting waarin gecontroleerd wordt voor leeftijddummies, geslacht, arbeidsmarktpositie (werkend of inactief), geboorte land (Nederland of buitenland) en opleidingsniveau. De geschatte waarden hebben betrekking op een gemiddelde persoon die betaald werk verricht.

Op basis van de econometrische analyse die ten grondslag ligt aan figuur 3.4 kunnen wij berekenen dat vanaf de leeftijd van 40 jaar de prozageletterdheid met 3,6\% per Io jaar deprecieert. Voor documentgeletterdheid is de depreciatie gelijk aan $4,8 \%$ per Io jaar. De depreciatievoet van de numerieke geletterdheid is iets lager: $3,4 \%$ per Io jaar.

\section{Verandering in de geletterdheid over de tijd}

Een andere manier om depreciatie van menselijk kapitaal te berekenen is door gebruik te maken van de twee metingen van geletterdheid in 1994 en 2008 de ontwikkeling van de functionele geletterdheid bij het ouder worden van personen in een bepaald leeftijdscohort te berekenen. Daarbij wordt de gemiddelde geletterdheid in een cohort in 1994 vergeleken met de score voor datzelfde cohort in 2008, dat wil zeggen: I4 jaar later. $^{15}$ De vergelijking in de testscores heeft weliswaar niet betrekking op dezelfde personen, maar op mensen uit hetzelfde cohort. Onder de veronderstelling dat beide

I5. Agarwal e.a. (2009) doen hetzelfde met HRS data, maar op individueel niveau omdat hun data longitudinale informatie van dezelfde personen bevat. 
steekproeven representatief zijn (wat na weging het geval is), kan deze synthetische cohort vergelijking van de testscores worden geïnterpreteerd als een directe maatstaf voor depreciatie van menselijk kapitaal.

\section{Figuur 3.5}

Depreciatie van de functionele geletterdheid over 14 jaar, naar leeftijd (in \%)'
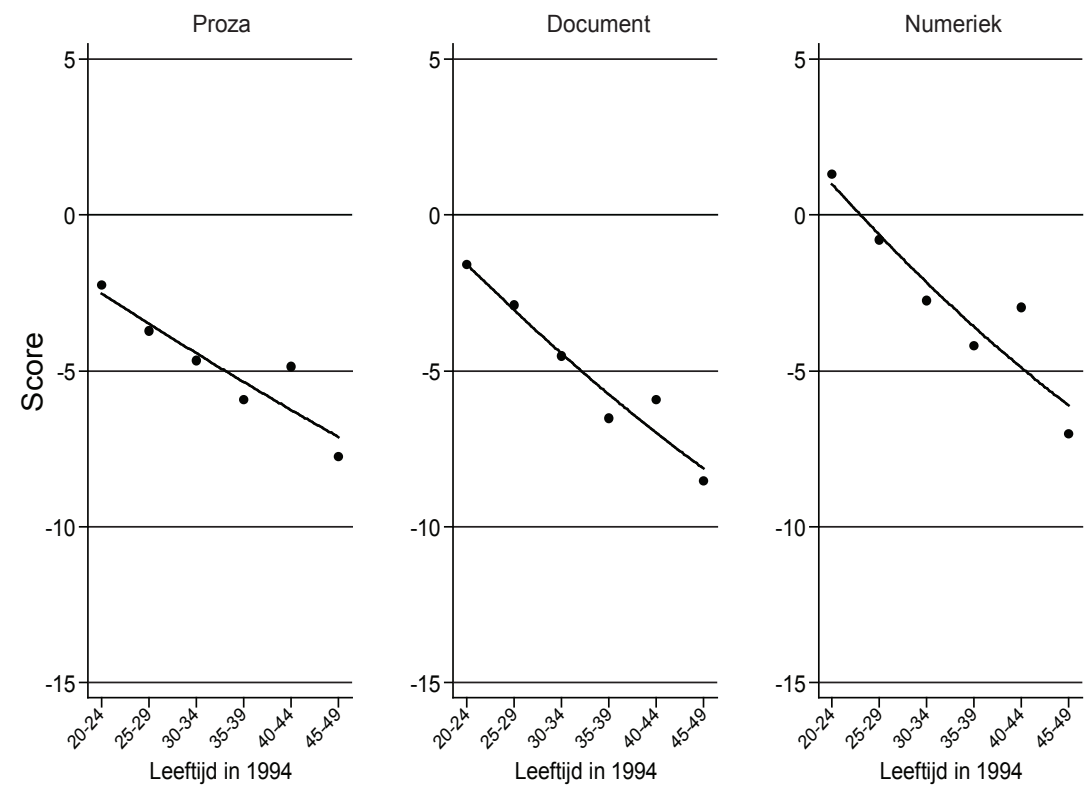

Bron: IALS, 1994; ALL, 2008

1. Verschil in functionele geletterdheid tussen 1994 en 2008 (uitgedrukt in procenten), naar leeftijdcohort in 1994. Personen ouder dan 50 jaar in 1994 zijn 64 jaar of ouder in 2008. Omdat de ALL data betrekking hebben op personen die niet ouder zijn dan 65 jaar is er geen informatie over de functionele geletterdheid van 50+ers in 2008.

Gemiddeld genomen is in I4 jaar tijd - de mensen zijn dus I4 jaar ouder geworden - de proza- en documentgeletterdheid gedaald met 4,6\% en de numerieke geletterdheid met $2,5 \%$. De geringere afname van de numeriek geletterdheid is te verklaren uit het feit dat de cognitietesten die de numerieke geletterdheid meten een groter beroep doen op 'cristallized intelligence' dan proza- en documentgeletterdheid. De procentuele verandering in de functionele geletterdheid tussen 1994 en 2008 is in figuur 3.5 afgebeeld voor de verschillende leeftijdscohorten. De afname van de geletterdheid is vanaf de leeftijd van 30 jaar significant: vanaf die leeftijd heeft men I4 jaar later - als men dan 44 jaar of ouder is geworden - gemiddeld een significant lager niveau van geletterdheid. De afname in de prozageletterdheid bij bijvoorbeeld de 40-49 jarigen bedraagt in absolute termen I8 punten. Ter vergelijking, het verschil in prozageletterdheid in 2008 tussen middelbaar en hoogopgeleiden bedraagt 23 punten. De afname in documentgeletterdheid onder 40-49 jarigen bedraagt in absolute termen 2I punten 
in 14 jaar. Ter vergelijking, het verschil in documentgeletterdheid tussen middelbaar en hoogopgeleiden bedraagt 24 punten. De afname in numerieke geletterdheid onder 40-49 jarigen in I4 jaar is I4 punten. Dit is een stuk minder dan het verschil in numerieke geletterdheid tussen middelbaar en hoogopgeleiden (29 punten).

Figuur 3.6

Depreciatie van de functionele geletterdheid over 14 jaar, naar leeftijd en opleidingsniveau (in \%)

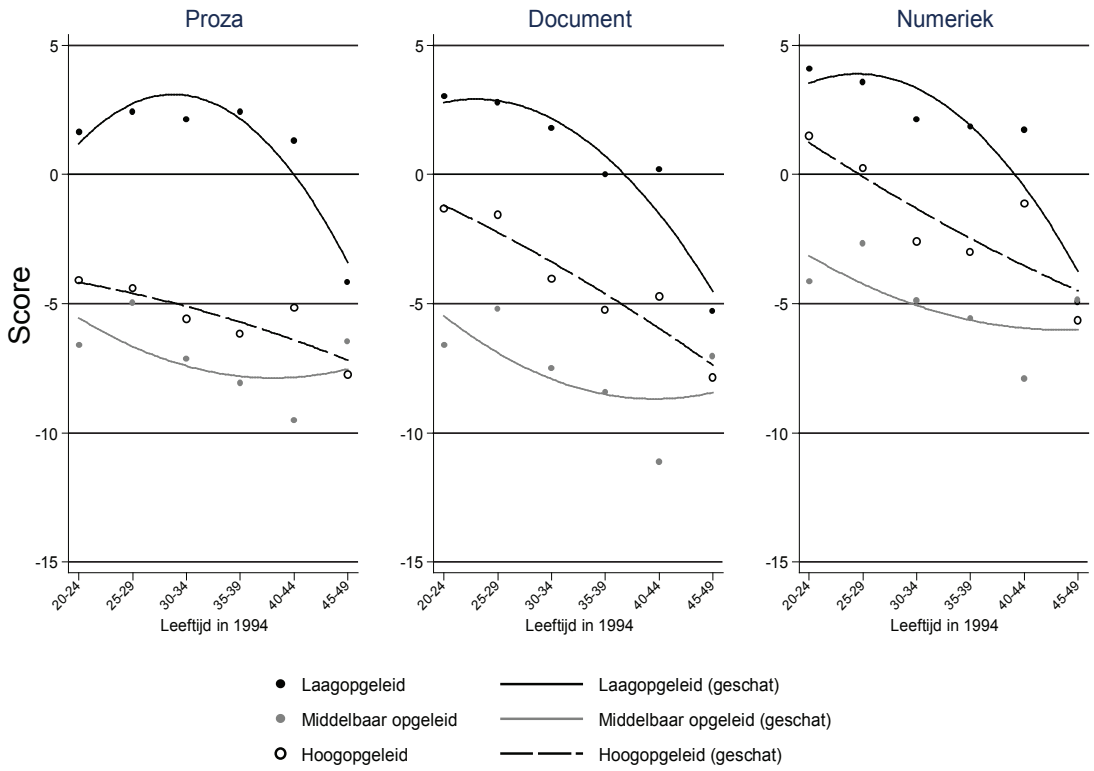

Bron: IALS, 1994; ALL, 2008

1. Verschil in geletterdheid tussen 1994 en 2008 (uitgedrukt in procenten), naar leeftijdcohort in 1994. Personen ouder dan 50 jaar in 1994 zijn 64 jaar of ouder in 2008. Omdat de ALL data betrekking hebben op personen die niet ouder zijn dan 65 jaar is de geen informatie over de functionele geletterdheid van de 50+ers in 2008.

Uit figuur 3.6 blijkt dat depreciatie van menselijk kapitaal niet gelijk is voor de verschillende opleidingsniveaus. De figuur geeft een beeld van de procentuele verandering in de testscores tussen 1994 en 2008, naar de leeftijd in 1994 en naar opleidingsniveau. De figuur laat zien dat voor laagopgeleiden de testscores in deze I4 jaar nauwelijks zijn veranderd. ${ }^{16}$ Daar staat tegenover dat laagopgeleiden al een relatief lagere score hebben. Alleen de score van de 45-49 jarigen in 1994 is 14 jaar later, wanneer men 59-63 jaar oud is, significant lager. De afname van de testscore is het grootst voor personen met een middelbaar opleidingsniveau. Ook voor hoogopgeleiden is de afname in geletterdheid groot en significant, al geldt dit in mindere mate

I6. Het gaat hier dus om een andere representatie dan het leeftijdsprofiel naar opleidingsniveau in figuur 3.3. Figuur 3.3. liet geen verschillen zien in de leeftijdsprofiel van geletterdheid naar opleiding. De hier besproken cijfers hebben betrekking op het effect van veroudering binnen leeftijdcohorten. 
voor de numerieke geletterdheid. De sterkere depreciatie voor personen met een middelbaar opleidingsniveau is opmerkelijk omdat verwacht wordt dat depreciatie sterker is naarmate het opleidingsniveau hoger is. Een mogelijke verklaring hiervoor is dat hoogopgeleiden vaker werkzaam zijn in banen waar geletterdheid belangrijk is waardoor depreciatie minder snel optreedt. Opgemerkt moet echter worden dat het verschil in depreciatie tussen middelbaar- en hoogopgeleiden wat proza geletterdheid betreft klein en niet significant is. Bovendien lijkt de depreciatie voor hoogopgeleiden sterker toe te nemen met de leeftijd.

\subsection{Cognitief vermogen op oudere leeftijd}

In de literatuur wordt er op gewezen dat het cognitief vermogen significant afneemt met de leeftijd (Salthouse, 2006). Figuur 3.7 geeft een overzicht van de ontwikkeling van de cognitie op basis van geheugentesten bij van Amerikanen, Europeanen en Nederlanders in de leeftijd van 50-90 jaar.

Figuur 3.7

Cognitief vermogen onder ouderen in Europa, Nederland en de VS op basis van geheugentest ${ }^{1}$

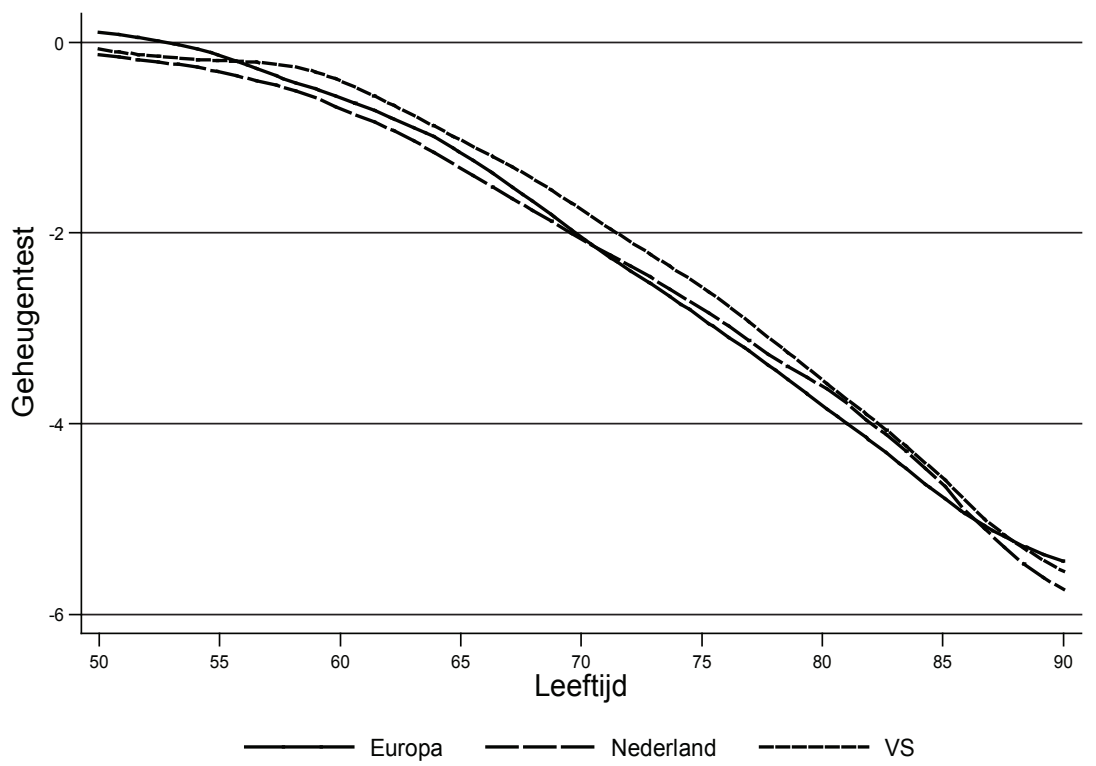

Bron: SHARE (2004-2006); HRS (1998-2006)

1. De afgebeelde scores hebben betrekking op het verschil in het aantal woorden dat een respondent van een bepaalde leeftijd zich weet te herinneren vergeleken met een 50 jarige persoon. 
Omdat de afgenomen testen verschillen tussen de landen zijn de scores genormaliseerd door het verschil te nemen met de score voor 50-jarigen. In deze geheugen test weten 50-jarigen zich ongeveer Io woorden te herinneren. Het verschil van -2 voor 70-jarigen in Nederland betekent dat 70 jarigen zich gemiddeld genomen 2 woorden minder weten te herinneren. Dit kan worden geïnterpreteerd als een afname van het cognitief vermogen van $20 \%$ tussen de leeftijden van 50 en 70 . De figuur laat dus duidelijk zien dat het cognitief vermogen afneemt met de leeftijd, en dat deze daling iets later wordt ingezet in de VS. Dit heeft mogelijk te maken met het feit dat er in de VS langer wordt doorgewerkt.

Figuur 3.8 laat vergelijkbare cijfers zien voor Nederland en de VS, maar maakt het onderscheid tussen werkenden en niet-werkenden. De score is hier genormaliseerd op basis van de score voor werkende 50-jarigen. Het cognitief vermogen van nietwerkenden blijkt duidelijk lager te zijn dan die van werkenden. Verder laat de figuur zien dat voor zowel werkenden als niet-werkenden de cognitieve vaardigheden afnemen met het stijgen van de leeftijd.

\section{Figuur 3.8}

Cognitief vermogen onder oudere werkenden en niet-werkenden in Nederland en de VS'

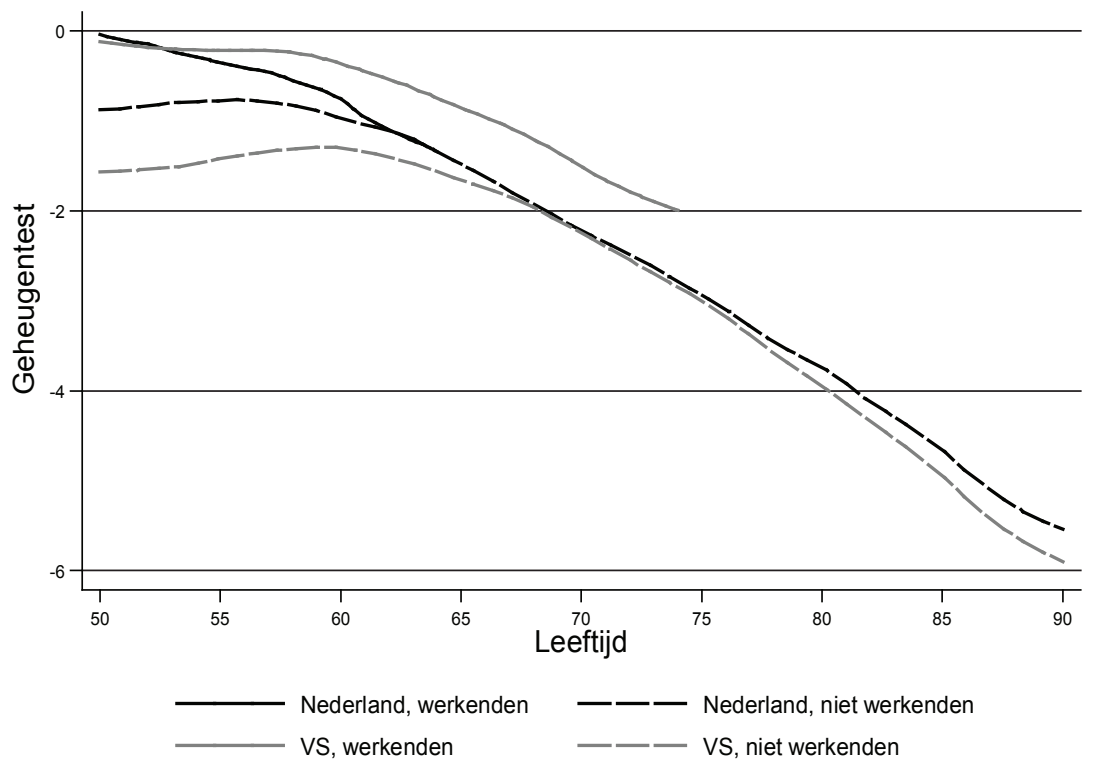

Bron: SHARE (2004-2006); HRS (1998-2006)

1. De afgebeelde scores hebben betrekking op het verschil in het aantal woorden dat een respondent van een bepaalde leeftijd zich weet te herinneren vergeleken met een 50 jarige persoon die betaald werk verricht. 
De vraag is waar het verschil in de cognitiescores tussen werkenden en niet-werkenden vandaan komt. Leidt uittreding tot verlies aan menselijk kapitaal? Of is het zo dat mensen met lagere cognitieve vaardigheden eerder de arbeidsmarkt verlaten? In een recent onderzoek laten Bonsang e.a. (20IO) zien dat er sprake is van een causaal verband tussen de arbeidsmarktuittrede en het verlies aan cognitief vermogen. $\mathrm{Na}$ correctie voor endogene zelf-selectie in het uittredegedrag laten de auteurs zien dat arbeidsmarktuittrede in de VS leidt tot een verlies van ongeveer IO\% van het cognitief vermogen. Het effect in Europa is daarmee vergelijkbaar. Deze bevinding is in lijn met de 'use it or lose it' hypothese.

\subsection{Eigen inschatting van het kennisniveau over de levensloop}

Zoals in paragraaf 3.2 reeds werd aangegeven, bevat de ROA Leven Lang Leren Enquête een tweetal vragen over het kennisniveau van respondenten. ${ }^{17}$ De vragen maken het mogelijk om een beeld te schetsen van de kennisontwikkeling over de levensloop. In de eerste plaats is aan respondenten gevraagd om zich voor te stellen welke kennis en vaardigheden nodig zijn om in hun werk optimaal te kunnen functioneren (voor werklozen: het werk dat zij het liefst zouden willen doen). Uitgaand van de waarde Ioo voor deze optimale situatie is vervolgens aan respondenten gevraagd om hun niveau van kennis en vaardigheden twee jaar geleden, en op het moment van de enquête aan te geven. Het betreft dus duidelijk een subjectieve inschatting van het eigen niveau van kennis en vaardigheden. Hoewel niet precies te zeggen is wat respondenten laten meewegen in hun oordeel, is het aannemelijk dat kennis en vaardigheden veel breder opgevat moet worden dan de in paragraaf 3.3 gebruikte geletterdheid, en dat het naast verschillende vormen van 'crystalized intelligence' ook competenties omvat die ook te maken met, bijvoorbeeld het vermogen om samen te werken en communicatieve vaardigheden.

In figuur 3.9 wordt het gemiddelde kennisniveau voor de verschillende leeftijdsgroepen in beeld gebracht. Op basis van de figuur kunnen twee belangrijke conclusies worden getrokken. Ten eerste stijgt het kennisniveau met de toenemende ervaring tot ongeveer 30 jaar. Daarna is het stabiel tot ongeveer 58 jaar, waarna het afneemt met het oplopen van de leeftijd. Ten tweede laat de vergelijking van het kennisniveau op het enquêtemoment met het kennisniveau van twee jaar geleden zien dat voor respondenten die jonger zijn dan 58 jaar het kennisniveau in de twee voorafgaande jaren is toegenomen, ook al wordt deze toename kleiner naarmate men ouder is. Daarbij moet wel de kanttekening worden gemaakt dat het hier gaat om de netto toename van iemands kennis. Dit betekent dat er wel degelijk sprake kan zijn van een depreciatie van menselijk kapitaal, maar dat deze kennisachteruitgang teniet gedaan wordt door een grotere investering in menselijk kapitaal. Na de leeftijd van 58 jaar neemt het kennisniveau echter af: voor deze leeftijdsgroep is het kennisniveau van

I7. Tenzij anders vermeld, zijn bij de analyses in deze paragraaf allen respondenten ongeacht leeftijd of arbeidsmarkt status meegenomen. 
twee jaar geleden, gemiddeld genomen, hoger dan het kennisniveau op het moment van de enquête. Dit duidt er op dat depreciatie van het kennisniveau zich met name manifesteert bij de oudere werkenden, omdat er op die leeftijd onvoldoende nieuwe investeringen in menselijk kapitaal tegenover staan. Een tweede kanttekening is dat in de enquête gevraagd wordt om de huidige functie als referentiepunt te hanteren. De data laat het echter niet toe om te controleren voor functie of baanveranderingen in de afgelopen twee jaar.

\section{Figuur 3.9}

Eigen inschatting van de kennisontwikkeling over de levensloop

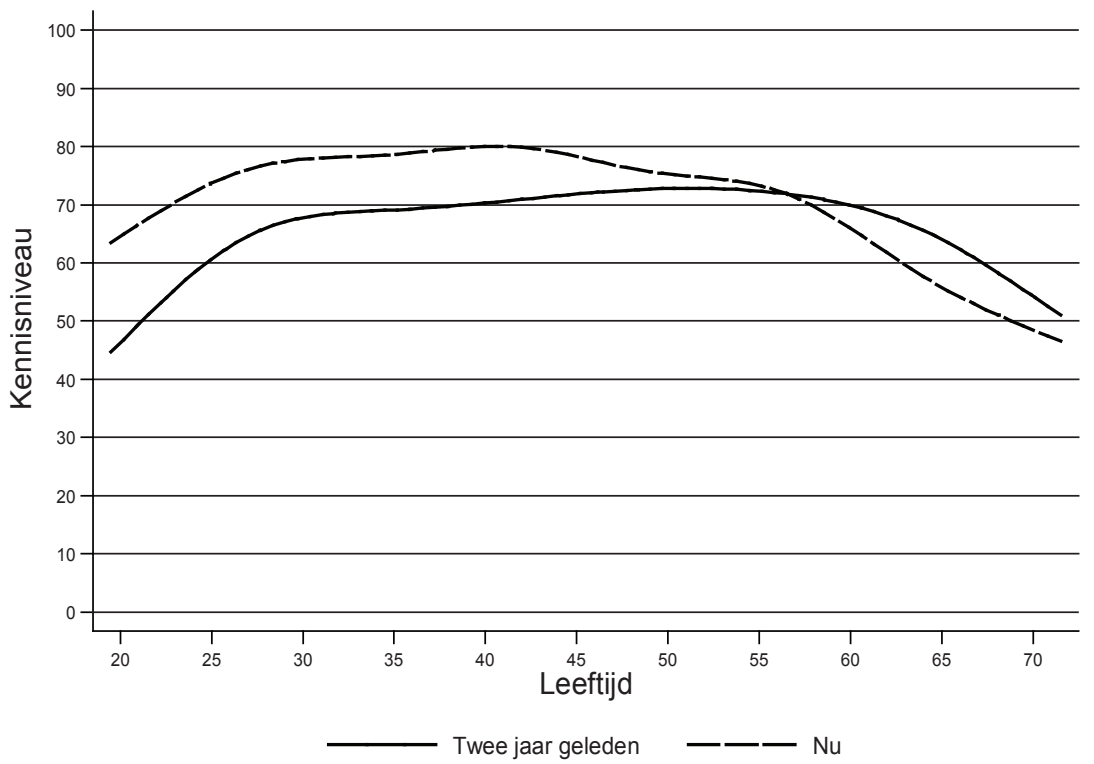

Bron: ROA Leven Lang Leren Enquête (2004, 2007)

Het verschil in kennisniveau op het moment van de enquête vergeleken met twee jaar geleden is in figuur 3.IO weergegeven voor mannen en vrouwen afzonderlijk. De afgebeelde lijnen komen overeen met het verschil tussen de lijnen in figuur 3.9, maar dan verbijzonderd naar geslacht. De figuur ${ }^{18}$ laat zien dat de depreciatie over de levensloop voor mannen niet anders blijkt te zijn dan voor vrouwen. Dit is verassend

I8. In figuur 3.IO wordt uitgegaan van de vergelijking van het verschil in kennisniveau nu en twee jaar geleden zoals gerapporteerd door de respondenten op het moment van de enquête. Omdat de $R O A$ Leven Lang Leren Enquête een longitudinaal karakter heeft (herhaalde meting onder dezelfde respondenten) is het ook mogelijk om de kennisontwikkeling te meten door het kennisniveau in 2007 te vergelijken met het kennisniveau in 2004. Door het gering aantal cases (als gevolg van panel uitval) kan de op deze wijze gemeten kennisontwikkeling niet in figuur 3.IO worden weergegeven. Echter, de kennisontwikkeling zoals deze wordt gemeten in de panel data correleert positief en significant met de kennisontwikkeling zoals die gemeten wordt op basis van de retrospectieve data. 
gezien vrouwen vaker met loopbaanonderbrekingen te maken hebben dan mannen. Dit duidt er op dat vrouwen na een loopbaanonderbreking in functies terecht komen waarvoor minder menselijk kapitaal vereist is, of dat vrouwen loopbaanonderbrekingen niet zien als gebeurtenissen die een impact hebben op hun menselijk kapitaal.

\section{Figuur 3.10}

Verandering in het kennisniveau (subjectief) in de afgelopen twee jaar, naar leeftijd en geslacht

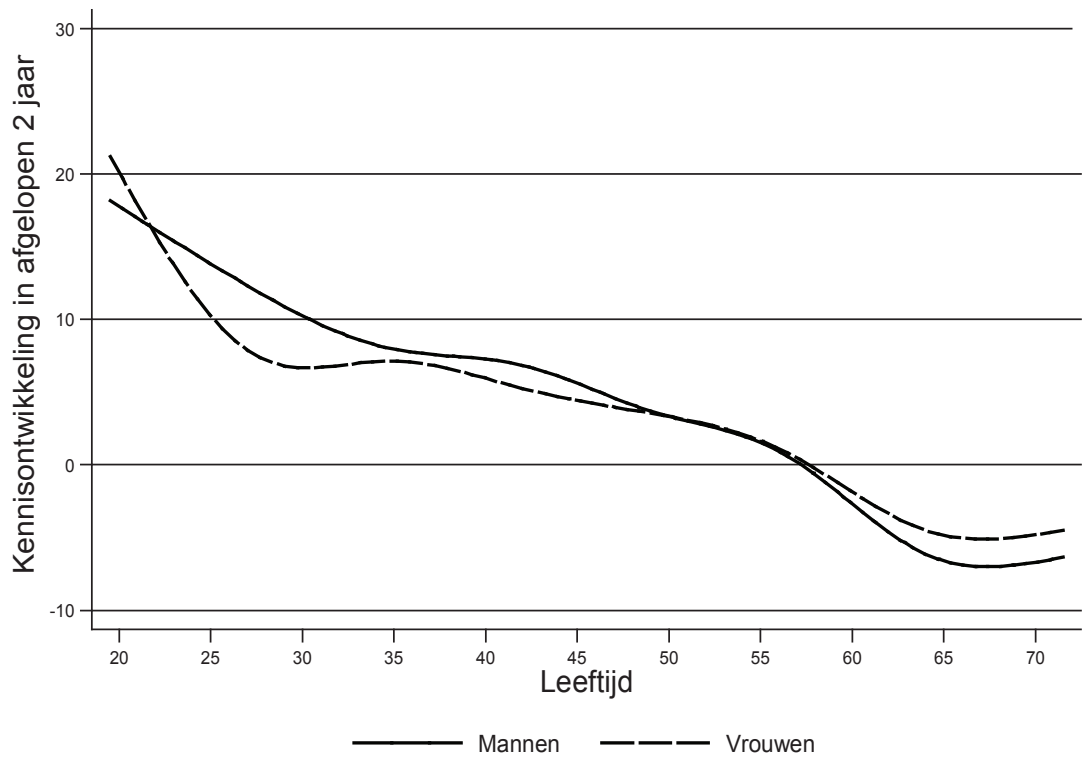

Bron: ROA Leven Lang Leren Enquête $(2004,2007)$

Hoogopgeleiden rapporteren een hoger kennisniveau dan laagopgeleiden, maar de verschillen zijn niet groot, ${ }^{19}$ en hun kennisontwikkeling verschilt niet veel. In figuur 3.II wordt de kennisontwikkeling gedurende de levensloop beschreven voor personen van verschillende opleidingsniveau. De figuur laat een opvallend gemeenschappelijk patroon zien in de kennisontwikkeling. De kennisontwikkeling wordt weliswaar op een latere leeftijd negatief voor laagopgeleiden, maar het patroon van depreciatie is sterk vergelijkbaar tussen de verschillende opleidingsniveaus.

I9. Anders dan bij de objectieve meting van de functionele geletterdheid dienen de respondenten hier bij de beantwoording van de vraag te denken aan hun eigen baan. Dit betekent dat hoger en lager opgeleide respondenten verschillende referentiekaders hanteren. 
Figuur 3.11

Verandering in kennisniveau (subjectief) in de afgelopen twee jaar, naar leeftijd en geslacht

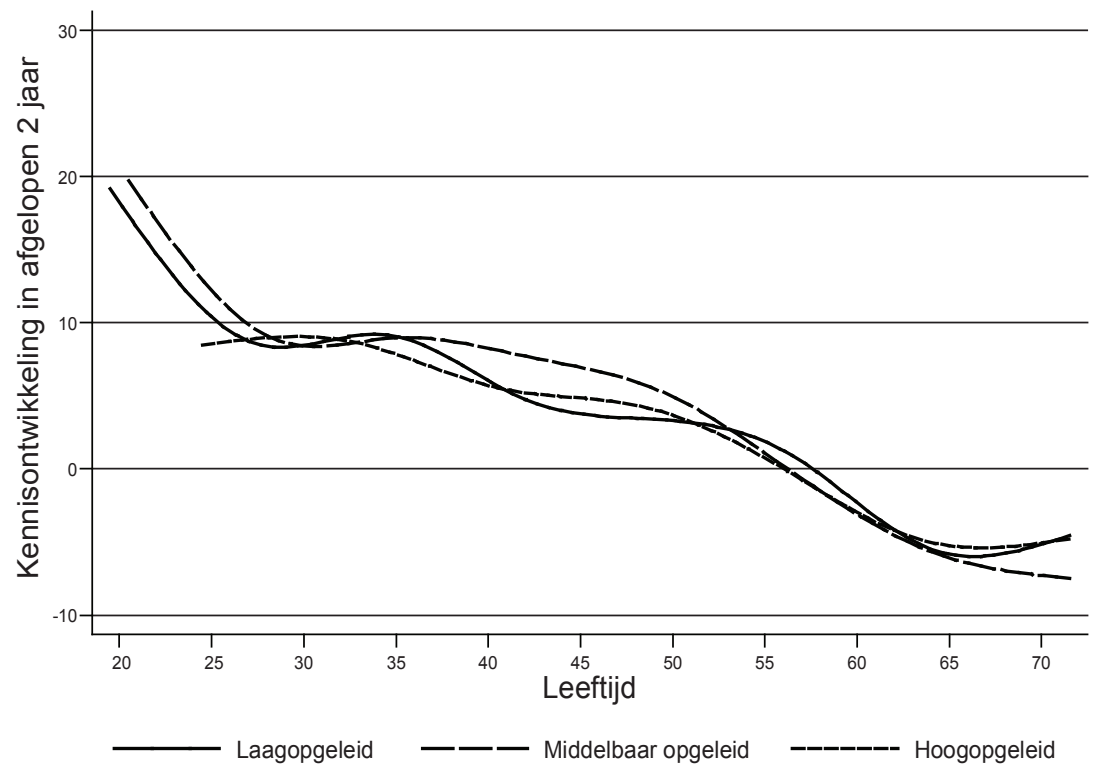

Bron: ROA Leven Lang Leren Enquête $(2004,2007)$

In figuur 3.12 wordt de kennisontwikkeling voor werkenden en inactieven (werkloos, arbeidsongeschikt, (vroeg-)gepensioneerden en andere niet-werkenden) apart in beeld gebracht. We zien dat de kennisontwikkeling bij de werkenden groter is dan bij de inactieven en dat het bovendien positief blijft tot men 65 jaar wordt. De afname van het kennisniveau bij de ouderen in figuur 3.9 heeft dus vooral betrekking op de kennisveroudering bij de inactieven. Bij inactieven wordt de kennisontwikkeling reeds vanaf de leeftijd van 50 jaar negatief.

In figuur 3.I3, tenslotte wordt de kennisontwikkeling van werkenden in deeltijd (minder dan 32 uur per week) en voltijd gepresenteerd. ${ }^{20}$ Het patroon van kennisontwikkeling over de leeftijd komt redelijk overeen tussen de twee groepen werknemers. Echter, de kennisontwikkeling is gemiddeld I, 5 procentpunt lager voor deeltijders vergeleken met voltijders. Nadere analyse laat zien dat de kennisontwikkeling toeneemt met het aantal gewerkte uren (zie de modelschattingen in tabel 3.I). Hoe dit verschil geïnterpreteerd dient te worden is niet geheel duidelijk (zie de bespreking in paragraaf 2.5). Het kan wijzen op een depreciatie van menselijk van deeltijders omdat zei een deel van het menselijk kapitaal niet gebruiken. Het kan ook duiden op het feit dat deeltijders minder in hun menselijk kapitaal investeren door middel van formele en informele scholing (Nelen en De Grip, 2009).

20. Het aantal gewerkte uren wordt niet gevraagd in de 2004 peiling van de ROA Leven Lang Leren Enquête. Deze wordt verkregen na een koppeling met de DNB Household Survey. 


\section{Figuur 3.12}

Verandering van het kennisniveau (subjectief) in de afgelopen twee jaar, naar leeftijd (niet ouder dan 65 jaar) en arbeidsmarkt status

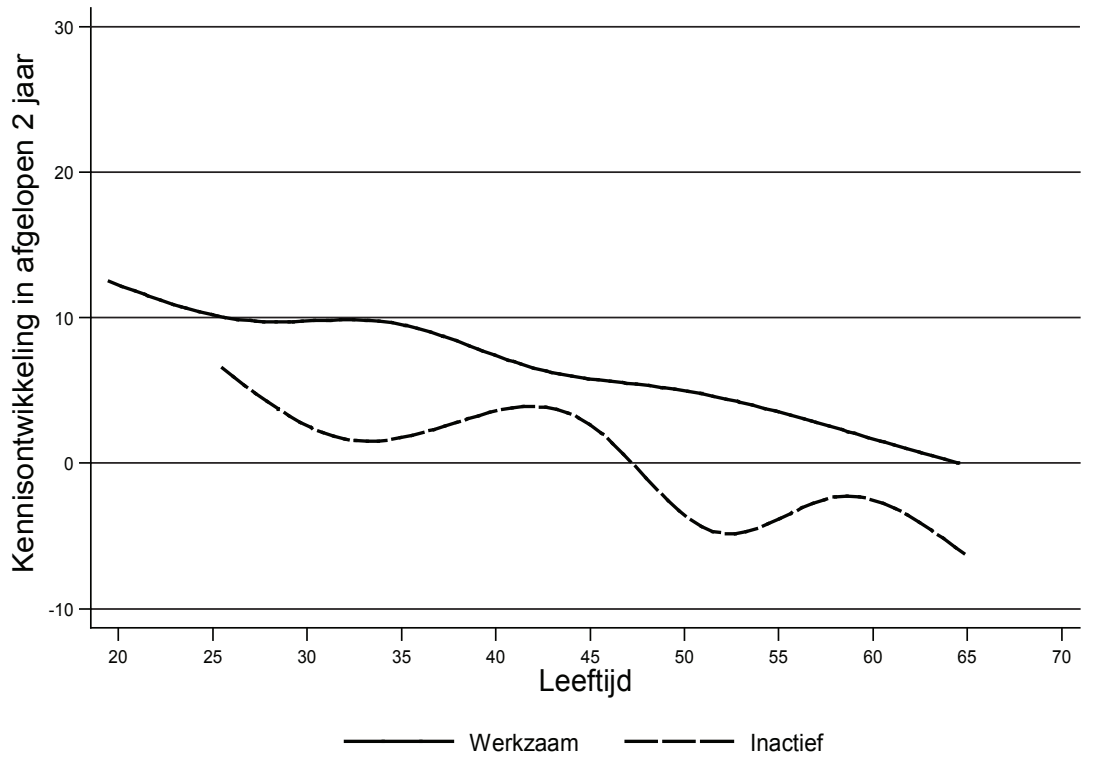

Bron: ROA Leven Lang Leren Enquête $(2004,2007)$ 
Figuur 3.13

Verandering van het kennisniveau (subjectief) in de afgelopen twee jaar, voltijds en deeltijd werkenden naar leeftijd op (niet ouder dan 65 jaar)

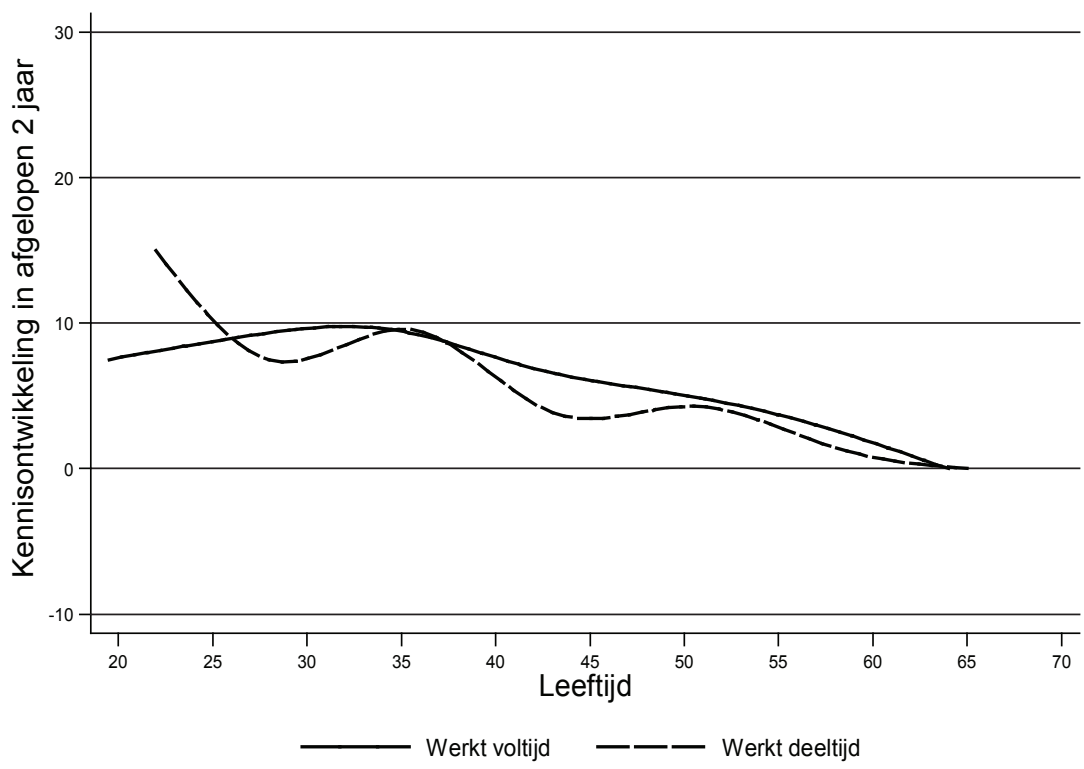

Bron: ROA Leven Lang Leren Enquête $(2004,2007)$

\section{Modelschattingen}

Tabel 3.I bevat de resultaten van een econometrische analyse van de kennisontwikkeling van werkenden in de afgelopen twee jaar. ${ }^{21}$ In de analyses wordt eerst gebruik gecontroleerd voor leeftijd, opleidingsniveau en geslacht om de kennisontwikkeling te verklaren (model I). Vervolgens wordt ook gecontroleerd voor de bedrijfssector waar iemand werkzaam is en een dummy voor deeltijd (model 2). Daarna, wordt het effect van de scholingsdeelname in de afgelopen 2 jaar bij de analyse betrokken, zonder dummy voor deeltijd (model 3). Vervolgens, wordt gecontroleerd voor zowel deeltijd als scholingsdeelname in de afgelopen 2 jaar (model 4 ). Tenslotte, wordt in een gevoeligheidsanalyse het onderscheid gemaakt tussen grote en middelgrote kleine deeltijdbanen (model 5).

De variabelen voor leeftijd zijn afzonderlijk niet significant, maar gezamenlijk wel. Het laat zien dat de kennisontwikkeling een maximum bereikt rond de leeftijd van 28 jaar. Omdat het totaal effect van leeftijd negatief is, kan men concluderen dat de

2I. Het betreft een OLS schatting van de subjectieve kennisontwikkeling in de afgelopen twee jaar. In de modellen is ook een controlevariabele opgenomen voor het peilingsjaar van de ROA Leven Lang Leren Enquête. Deze bleek niet significant. De standaardfouten in de tabel zijn gecorrigeerd voor het feit dat sommige respondenten aan beide metingen hebben meegedaan. 
kennisontwikkeling steeds kleiner wordt naarmate iemand ouder wordt: na de leeftijd van 28 jaar daalt de gemiddelde kennisontwikkeling elke 3 jaar met I procentpunt.

Hoogopgeleiden blijken te maken te hebben een sterkere mate van kennisdepreciatie dan lager opgeleiden. Hun kennisontwikkeling is gemiddeld 2 procentpunten lager dan voor de werkenden met een mbo of lager opleidingsniveau. Hier kunnen twee effecten een rol spelen: I) het hogere kennisniveau van hoogopgeleiden maakt het moeilijker om een nog hoger kennisniveau te bereiken (plafond effect), 2) depreciatie van menselijk kapitaal is gemiddeld genomen sterker omdat de verschuivingen in de gevraagde kennis en vaardigheden als gevolg van technologische en organisatorische vernieuwingen groter is dan bij lager opgeleiden (zie ook Weinberg, 2002). Zoals figuur 3.Io reeds aangaf, blijkt de kennisontwikkeling bij vrouwen niet verschillend te zijn van de kennisontwikkeling van mannen.

De gegevens in tabel 3.I later ook interessante sectorale verschillen zien. Zo blijkt de kennisontwikkeling in de sectoren bouw (bijna 4 procentpunten) en overheid ( 2 procentpunten) op een significant hoger niveau te liggen dan bij andere sectoren. Echter, het verloop van de kennisontwikkeling gedurende de levensloop is in deze sectoren niet anders dan in andere sectoren. De kennisontwikkeling neemt in dezelfde mate af met het stijgen van de leeftijd als in andere sectoren. Werk in deeltijd gaat gepaard met een lagere kennisontwikkeling van min I, 8 procentpunten (in model 2). ${ }^{22}$ Het is echter interessant om op te merken dat dit effect, zo is gebleken uit gevoeligheidsanalyses in model 5, vooral te wijten is aan de negatieve kennisontwikkeling onder deeltijders met een klein of middelgrote deeltijdbaan (minder dan 28 uur per week). Voor werkenden met een grote deeltijdbaan ( 28 uur per week of meer, maar minder dan 32 uur) is geen sprake van een significant lager niveau van kennisontwikkeling.

Het in hoofdstuk 2 gepresenteerde model voor depreciatie van menselijk kapitaal (Model (I)) dat bijscholing een positief effect kan hebben op de kennisontwikkeling. Uit tabel 3.I blijkt dat werkenden die in de afgelopen 2 jaar een werkgerelateerde cursus hebben gevolgd gemiddeld genomen een geringere kennisdepreciatie hebben (I procentpunt). Ook blijkt dat het patroon van depreciatie over de levensloop vlakker verloopt voor werkenden die cursussen volgen dan voor werkenden die geen cursussen volgen. Zelfs op hogere leeftijd blijft de kennisontwikkeling van werkenden die een cursus hebben gevolgd in de afgelopen twee jaar positief. Hoe de causaliteit tussen kennisdepreciatie en cursusdeelname precies verloopt, valt op basis van deze analyses niet te zeggen. Het kan zijn dat het volgen van cursussen depreciatie van menselijk tegengaat. Maar het ook mogelijk dat juist werkenden wiens kennis niet veel waarde verliest een grotere kans hebben op het volgen van cursussen. Wanneer zowel voor werk in deeltijd als scholingsdeelname wordt gecontroleerd (model 4), dan blijkt het effect nog steeds positief te zijn, maar niet meer significant. Het feit dat deeltijd werk-

22. Indien uitgegaan wordt van de CBS definitie van deeltijd (werk voor 34 uur of minder), dan is het effect van werk in deeltijd iets kleiner ( $\mathrm{min} \mathrm{I}, 3$ procentpunten en allen significant op IO\%). 
nemers minder aan scholing doen (Nelen en De Grip, 2009) is mogelijk de oorzaak van het insignificant worden van de dummy voor scholing.

Tabel 3.1

Regressiemodel voor kennisontwikkeling (subjectief) van werkenden in de afgelopen twee jaar'

\begin{tabular}{|c|c|c|c|c|c|}
\hline & Model 1 & Model 2 & Model 3 & Model 4 & Model 5 \\
\hline Leeftijd & 1,321 & 1,378 & 1,153 & 1,338 & 1,345 \\
\hline Leeftijd^2(*0,01) & $-3,426$ & $-3,521$ & $-3,009$ & $-3,428$ & $-3,447$ \\
\hline Leeftijd $\wedge 3\left({ }^{*} 0,001\right)$ & 0,233 & 0,239 & 0,201 & 0,233 & 0,235 \\
\hline \multicolumn{6}{|l|}{ Opleiding (ref: lage opleiding) } \\
\hline Middelbare opleiding & $-0,171$ & $-0,310$ & $-0,251$ & $-0,319$ & $-0,313$ \\
\hline Hoogopgeleid & $-2,014^{* * *}$ & $-2,127^{* *}$ & $-2,021^{* *}$ & $-2,218^{* *}$ & $-2,231^{* *}$ \\
\hline Vrouw (ref: man) & 0,358 & $1,178^{*}$ & 0,643 & $1,215^{*}$ & $1,225^{*}$ \\
\hline \multicolumn{6}{|l|}{ Sector (ref: industrie) } \\
\hline Bouw & & $3,867^{* *}$ & $3,768^{* *}$ & $3,817^{* *}$ & $3,816^{* *}$ \\
\hline Handel en horeca & & 1,448 & 1,361 & 1,495 & 1,502 \\
\hline Transport & & 1,235 & 1,222 & 1,142 & 1,148 \\
\hline Commerciële en financiële dienstverlening & & 1,065 & 0,954 & 1,016 & 1,020 \\
\hline Overheid & & $2,182^{* *}$ & $1,986^{*}$ & $2,047^{*}$ & $2,034^{*}$ \\
\hline Semi-overheid & & $-0,175$ & $-0,265$ & $-0,093$ & $-0,103$ \\
\hline Onderwijs & & 0,472 & 0,305 & 0,423 & 0,416 \\
\hline Zorg en welzijn & & 0,634 & 0,185 & 0,491 & 0,501 \\
\hline \multicolumn{6}{|l|}{ Gewerkte uren } \\
\hline Deeltijd (< 32 uur per week) & & $-1,793^{* *}$ & & $-1,716^{* *}$ & \\
\hline Middelgroot of klein deeltijd² & & & & & $-1,840^{* *}$ \\
\hline Groot deeltijd ${ }^{3}$ & & & & & $-1,225$ \\
\hline Cursus gevolgd in afgelopen 2 jaar & & & $0,935^{*}$ & 0,848 & 0,838 \\
\hline Constante term & $-4,082$ & $-6,144$ & $-3,498$ & $-6,065$ & $-6,162$ \\
\hline R-kwadraat (adjusted) & 0,054 & 0,057 & 0,056 & 0,058 & 0,057 \\
\hline N & 2178 & 2162 & 2162 & 2162 & 2162 \\
\hline
\end{tabular}

Standaardfout tussen haakjes

${ }^{*} p<0,10 * * p<0,05 * * * 0<0,01$

1 Schattingen voor werkenden jonger dan 65 jaar.

2 Minder dan 28 uur per week.

3 Van 28 tot 32 uur per week.

Bron: ROA Enquête Leven Lang Leren, 2004 en 2007 


\subsection{Conclusie en discussie}

In dit hoofdstuk is gebruik gemaakt van een drietal directe indicatoren om depreciatie van menselijk kapitaal over de levensloop in kaart te brengen:

- indicatoren voor de functionele geletterdheid;

- cognitieve geheugen testen;

- subjectieve inschatting van de eigen kennisontwikkeling.

De analyses met betrekking tot de functionele geletterdheid van mensen laten zien dat er gedurende de levensloop sprake is van een afname van de verschillende vormen van geletterdheid. Voor zover iemands functionele geletterdheid een goede indicator is voor zijn of haar menselijk kapitaal, dan is de voorlopige conclusie dat het menselijk kapitaal na het verlaten van het initiële onderwijs op significante wijze deprecieert over de levensloop. Deze depreciatie doet zich vooral voor na de leeftijd van 40 jaar. Ook geheugentesten laten zien dat iemands cognitie op oudere leeftijd afneemt. Deze afname van iemands cognitie is groter bij mensen die uit het arbeidsproces zijn getreden.

De testen van iemands functionele geletterdheid en geheugentesten meten vaardigheden die belangrijk zijn voor het functioneren op het werk en in het dagelijks leven. Functionele geletterdheid is bijvoorbeeld noodzakelijk om schriftelijk informatie en instructies goed te kunnen begrijpen, zelfs in banen op een laag niveau. Toch meet dit natuurlijk slechts een bepaald aspect van iemands menselijk kapitaal. Verschillende productieve vaardigheden zoals bijvoorbeeld communicatieve vaardigheden, of het vermogen om samen te werken staan grotendeels los van iemands functionele geletterdheid. Mede om die reden is in dit hoofdstuk ook gekeken naar een subjectieve maatstaf voor iemands menselijk kapitaal, namelijk het beeld dat men heeft van de eigen kennisontwikkeling. Uit onze analyses van de kennisontwikkeling van de Nederlandse beroepsbevolking komt naar voren dat de kennis met het stijgen van de leeftijd steeds minder toeneemt om vervolgens, rond de leeftijd van 58 jaar zelfs af te nemen. Het is echter belangrijk om op te merken dat het kennisniveau van werkenden niet daalt. Ook blijkt dat de kennis van werkenden die de afgelopen twee jaar cursussen hebben gevolgd significant minder snel deprecieert. Dit effect gaat echter niet op wanneer gecontroleerd wordt voor het al of niet werken in deeltijd. Deeltijdwerk blijkt een sterk negatief effect te hebben op iemands kennisontwikkeling en is ook negatief gecorreleerd met de deelname aan scholing. Echter, het is belangrijk om op te merken dat het negatieve effect van deeltijdwerk op de kennisontwikkeling geheel is toe te schrijven aan de negatieve kennisontwikkeling van werknemers met een middelgrote of kleine deeltijdbaan. De kennisontwikkeling van werknemers met een grote deeltijdbaan verschilt niet van die van werknemers in een voltijdbaan.

In dit hoofdstuk is aangesloten bij de recente literatuur waarin het menselijk kapitaal aan de hand van directe indicatoren gemeten wordt. De vraag is echter in welke mate de op deze wijze gemeten ontwikkeling van het menselijk kapitaal over de levensloop overeenkomt met meer gangbare indirecte maatstaven zoals het loon. Dit is 
van belang in het kader van de maatschappelijke discussie rond de inzetbaarheid van oudere werknemers. Figuur 3.I4 laat de ontwikkeling van het mediaan netto uurloon naar leeftijd zien voor mannen en vrouwen op basis van het OSA-Arbeidsaanbodpanel 1986-2006. De afgebeelde zwarte lijn is de helling van het loon-leeftijdsprofiel.

Uit de figuur blijkt dat het loon stijgt met de leeftijd, zij het in afnemende mate tot de leeftijd van 52 jaar voor mannen en 46 jaar voor vrouwen, om vervolgens licht af te nemen. Het patroon van de loonontwikkeling vertoont opmerkelijke overeenkomsten met het patroon van de door de betrokkenen zelf gepercipieerde ontwikkeling van zijn of haar kennisniveau, zoals eerder in dit hoofdstuk besproken. Dit is te zien aan de gestippelde lijn in de figuur dat de procentuele verandering in het kennisniveau van werkenden weergeeft. ${ }^{23}$ Het kennisniveau laat een vlakker ontwikkelingspatroon zien dan het loon, maar de correlatie tussen kennis- en loontwikkeling is hoog: 0,98 . Voor mannen bereikt de ontwikkeling van het loon en van het kennisniveau het o-punt rond dezelfde leeftijd. Voor vrouwen ligt het o-punt voor de ontwikkeling van het kennisniveau op een latere leeftijd dan het o-punt voor de loonontwikkeling.

Figuur 3.14

Loonontwikkeling en kennisontwikkeling (subjectief) van mannen en vrouwen naar leeftijd

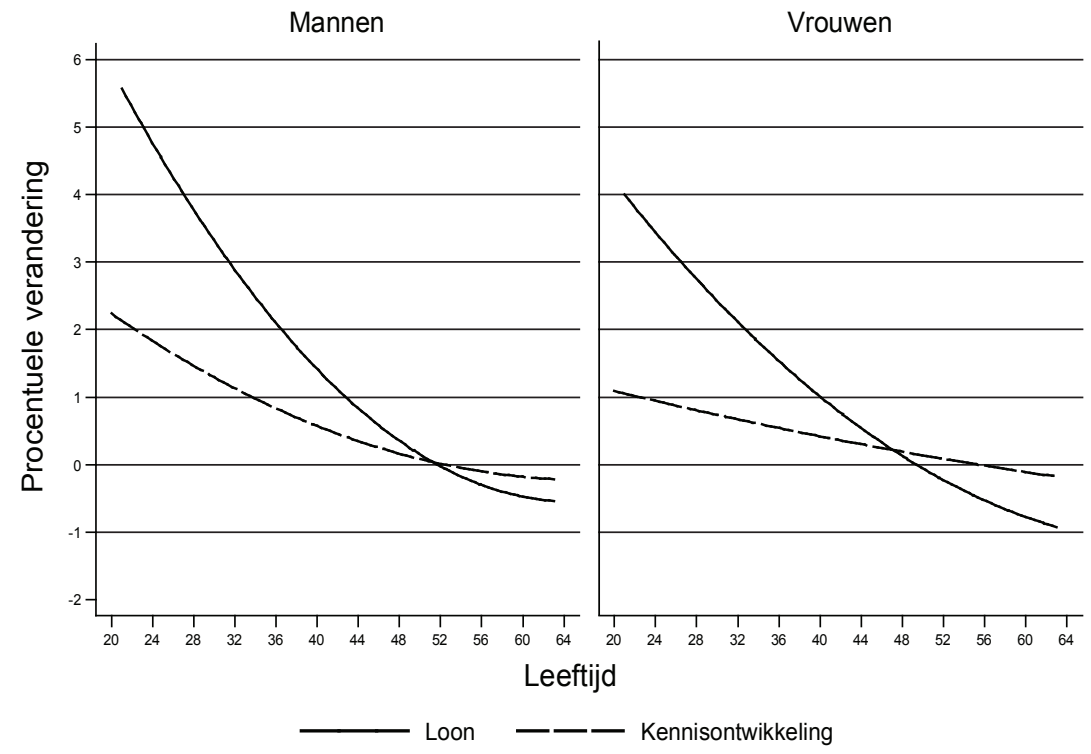

Bron: OSA-Arbeidsaanbodpanel (1986-2006); ROA Leven Lang Leren Enquête (2004, 2007)

23. Het gaat hier om soortgelijke cijfers als in figuur 3.Io, maar dan alleen voor werkenden. 
Echter, de objectieve testen met betrekking tot iemands niveau van functionele geletterdheid laten zien dat iemands menselijk kapitaal al op veel jongere leeftijd deprecieert. Hoe kunnen deze bevindingen aan elkaar worden gerelateerd? Ten eerste is het van belang om nogmaals op te merken dat geletterdheid en cognitieve testscores belangrijke vaardigheden die op de arbeidsmarkt van grote waarde zijn niet meten. Denk bijvoorbeeld aan vaardigheden als flexibiliteit, communicatieve vaardigheden, en dergelijke. Ten tweede meten cognitietesten - en waarschijnlijk ook de functionele geletterdheidtesten - iemands 'fluid intelligence' en niet de 'cristallized intelligence' (Cattell, 1983) waaronder de vakspecifieke kennis en vaardigheden, die zeer bepalend kunnen zijn voor de waarde van iemands menselijk kapitaal. Ten derde weerspiegelt het loon vaak slechts ten dele het menselijk kapitaal waarover iemand beschikt, omdat diverse instituties een bepaalde loonrigiditeit veroorzaken. Bovendien is het mogelijk dat loonafspraken tussen werkgevers en werknemers een rol spelen. Het gaat hier om afspraken waarbij de werknemer een loon onder het marginaal product accepteert in ruil voor een hoger loon, boven het marginaal product, later in de loopbaan. Bij deze 'backloading' van de beloning (Lazear, 1979) weerspiegelt het loon op later leeftijd niet de waarden van het menselijk kapitaal. 


\section{Depreciatie van menselijk kapitaal door loopbaanonderbrekingen vanwege zorgtaken}

\subsection{Inleiding}

In hoofdstuk 3 zijn directe indicatoren van de waarde van het menselijk kapitaal, en de ontwikkeling daarvan naar leeftijd aan bod gekomen. In dit hoofdstuk leggen wij de focus op het effect van loopbaanonderbrekingen vanwege zorgtaken op depreciatie van menselijk kapitaal. Daarbij zal worden ingegaan op de volgende twee vragen:

- Wat is effect van de duur van loopbaanonderbrekingen vanwege zorgtaken op de kans op werk?

- Wat is effect van de duur van loopbaanonderbrekingen vanwege zorgtaken op het baanniveau na de onderbreking?

Het merendeel van het onderzoek naar de effecten van loopbaanonderbrekingen heeft plaatsgevonden aan de hand van paneldata. Een nadeel hiervan is dat paneldata vaak slechts betrekking hebben op een korte periode. Het banenbestand van het SSB heeft bijvoorbeeld slechts betrekking op een periode van negen jaar, namelijk 1999-2007. Het OSA-Arbeidsaanbodpanel bestrijkt weliswaar een lange periode (1985-2006), maar kampt met paneluitval waardoor respondenten meestal niet lang in de tijd kunnen worden gevolgd. Door deze beperkingen van de data kan niet altijd een goed overzicht worden gegeven van de consequenties die loopbaanonderbrekingen hebben op de baankans en het loon gedurende de levensloop. Om hier toch meer inzicht in te krijgen kunnen we het beste gebruik maken van de Family Survey of the Dutch Population. Het betreft retrospectieve paneldata onder een representatieve steekproef van de Nederlandse beroepsbevolking.

Dit hoofdstuk is als volgt opgebouwd. Eerst geven wij in paragraaf 4.2 een beschrijving van de data en de gebruikte variabelen. In paragraaf 4.3 documenteren we het patroon van arbeidsparticipatie van Nederlandse mannen en vrouwen over de gehele levensloop en presenteren we schattingen van het effect van de duur van loopbaanonderbrekingen vanwege zorgtaken op de kans op werk. Paragraaf 4.4 staat in het teken van het effect van loopbaanonderbrekingen vanwege zorgtaken op het beroepsniveau. Paragraaf 4.5 concludeert. 


\subsection{Data}

In dit hoofdstuk wordt gebruik gemaakt van de Family Survey of the Dutch Population. Het gaat hier om retrospectieve paneldata die betrekking hebben op een representatieve steekproef van de Nederlandse beroepsbevolking (zie De Graaf e.a., 2003). In het onderzoek wordt de volledige arbeidsmarktgeschiedenis en de volledige demografische geschiedenis van de respondenten tot aan de datum van de enquête in kaart gebracht. Wij maken gebruik van de peilingen 1992/1993, I995, I998, 2000 en 2003, met in totaal bijna II.00o respondenten. Het gaat om de volgende databronnen die in een bestand zijn samengebracht: de Netherlands Family Survey 1992-1993 (Ultee en Ganzeboom, 1993); de Survey Households in the Netherlands I995 (Weesie en Kalmijn, I995); de Family Survey Dutch Population 1998 (De Graaf e.a., I998); de Family Survey Dutch Population 2000 (De Graaf e.a., 2000); en de Family Survey Dutch Population 2003 (De Graaf e.a., 2003). ${ }^{24}$

Op basis van deze unieke databron kan de volledige carrière van respondenten worden gereconstrueerd en econometrisch worden geanalyseerd. Voor de analyses zijn respondenten in de leeftijd van 18 tot 60 jaar geselecteerd. ${ }^{25}$ In de dataset is iemands arbeidsmarktstatus in elke maand beschikbaar. Daarbij wordt echter slechts een onderscheid gemaakt tussen perioden van werk en inactiviteit. Aan de hand van het aantal gewerkte uren kan een onderscheid worden gemaakt tussen periodes van werk in een voltijdsbaan en deeltijdwerk (minder dan 32 uren per wek). Inactiviteit betreft zowel werkloosheid als inactiviteit wegens de zorg voor kinderen of om andere redenen. Voortbouwend op het werk van Fouarge e.a. (20IO) kunnen aan de hand van de beschikbare informatie rond de gezinsformatie en de geboorte van kinderen periodes van inactiviteit worden gekenmerkt als inactiviteit vanwege de zorg voor kinderen of andere vormen van inactiviteit (doorgaans werkloosheid). Dit betekent dat de analyses toegespitst kunnen worden op inactiviteit wegens de zorg voor kinderen. Dit doen wij door de analyses nader toe te spitsen op periodes van inactiviteit die binnen de twee jaar voor of na de geboorte van kinderen zijn begonnen. Het effect van werkloosheid op depreciatie van menselijk kapitaal zal in het volgende hoofdstuk centraal staan.

De surveys bevatten informatie over de loongegevens van werkenden. Deze informatie is echter niet retrospectief verzameld en is dus alleen beschikbaar voor de baan die men heeft op het moment van enquête. De loongegevens zullen niet worden gebruikt. De informatie over iemands beroep is echter wel retrospectief beschikbaar voor elke baan die men heeft gehad. De beroepencodes zijn omgecodeerd naar de ISEI indeling voor de sociaaleconomische status van het beroep, een veelgebruikte indeling die sterk correleert met het loon (Ganzeboom e.a., 1992). Deze ISEI inde-

24. Met dank aan Ruud Luijkx voor het beschikbaar stellen van de data.

25. Eerder zijn deze data gebruikt om het effect van het krijgen van kinderen op het arbeidsaanbod van verschillende cohorten vrouwen te schatten (Fouarge e.a., 20Io) en het effect van inactiviteit in de eerste drie jaar na het verlaten van school op de arbeidsmarktpositie later in de loopbaan (Luijkx en Wolbers, 2009). 
ling is een continue indeling van beroepsniveaus tussen de waarden Io en 9o, waarbij hogere waarden een hoger beroepsniveau impliceren, en dus een hoger loon.

De in dit hoofdstuk uitgevoerde analyses zijn geïnspireerd door het in hoofdstuk 2 besproken werk van Mincer en Ofek (1982) en Mincer en Polachek (1974). Eerst schatten we een duurmodel voor inactieven waarbij de kans op participatie afhankelijk is van de duur van inactiviteit en andere waarneembare en niet waarneembare kenmerken van het individu. Eerst wordt het duurmodel geschat voor alle soorten inactiviteit. Vervolgens wordt het model opnieuw geschat voor inactiviteit i.v.m. de zorg voor kinderen (periodes van inactiviteit die twee jaar voor of twee jaar na de geboorte van een kind zijn begonnen). In verband met onze focus op depreciatie van menselijk kapitaal worden alleen duren van inactiviteit meegenomen indien een periode van arbeidsparticipatie daar aan vooraf is gegaan. Daarna relateren wij iemands sociaaleconomische status aan de duur van eerdere perioden van inactiviteit en de eerder opgedane arbeidsmarktervaring.

Een belangrijke meerwaarde van de data is, zoals gezegd, dat we de effecten van een loopbaanonderbreking op lange termijn kunnen vaststellen Gelet op dit langetermijnperspectief, en omdat het patroon van de arbeidsmarktdeelname van vrouwen tussen de verschillende geboorte cohorten van vrouwen sterk is veranderd (Bosch, e.a., 20IO), zal in de analyses worden gecontroleerd voor cohort effecten. Verder zal in de analyses worden gecontroleerd voor het beroep dat iemand voor de loopbaanonderbreking uitoefende. Dit is van belang omdat eerder onderzoek op basis van Duitse data heeft laten zien dat depreciatie van menselijk kapitaal eerder beroeps- dan sectorspecifiek is en ook sterk kan verschillen tussen functies op lager en hoger niveau en tussen "mannen- en vrouwenberoepen" (Görlich en De Grip, 2009).

\subsection{Kans op herintrede}

\section{Beschrijvende statistieken: arbeidsaanbod in de levensloop}

Alvorens in te gaan op de participatiekans na inactiviteit, bespreken wij eerst kort een aantal feiten met betrekking tot de arbeidsparticipatie van Nederlandse mannen en vrouwen. Figuren 4.I en 4.2 laten zien dat het arbeidsaanbod van mannen en vrouwen fluctueert over de leeftijd en dat deze ontwikkeling verschillend is voor verschillende geboortecohorten. Bij mannen (figuur 4.I) stijgt de arbeidsparticipatie met de leeftijd voor alle cohorten om bij het bereiken van de leeftijd van 50 jaar langzeem af te nemen. Daarbij is het opvallend dat mannen uit het oudste cohort (geboren tussen I90o en I930) gemiddeld genomen vaker werk hadden en ook langer zijn blijven doorwerken. Het stijgende opleidingsniveau in Nederland kan verklaren waarom de arbeidsparticipatie op jonge leeftijd voor opeenvolgende cohorten steeds lager is geworden. Het effect van vervroegd uittreden is duidelijk zichtbaar in de figuur, waarbij opgemerkt 
kan worden dat de participatiegraad in de jongste cohort hoger lijkt te liggen dan bij de cohort I95I-I960.

Het levenscycluspatroon van de arbeidsparticipatie bij vrouwen (figuur 4.2) is heel anders dan dat van mannen. Afhankelijk van de geboortecohort stijgt de participatie tot de leeftijd van 20 tot 26 jaar. Als gevolg van het stijgende opleidingsniveau en het stijgen van de leeftijd waarop vrouwen hun eerste kind krijgen is deze leeftijd steeds hoger komen te liggen. Vanaf die leeftijd neemt de arbeidsparticipatie van vrouwen weer af als gevolg van de geboorte van kinderen, om daarna weer te stijgen. De daling in de arbeidsparticipatie vanwege het krijgen van kinderen is kleiner, en de stijging in de jaren daarna scherper bij opeenvolgende geboortecohorten. ${ }^{26}$

\section{Figuur 4.1}

Arbeidsaanbod van mannen over de levensloop naar geboortecohort

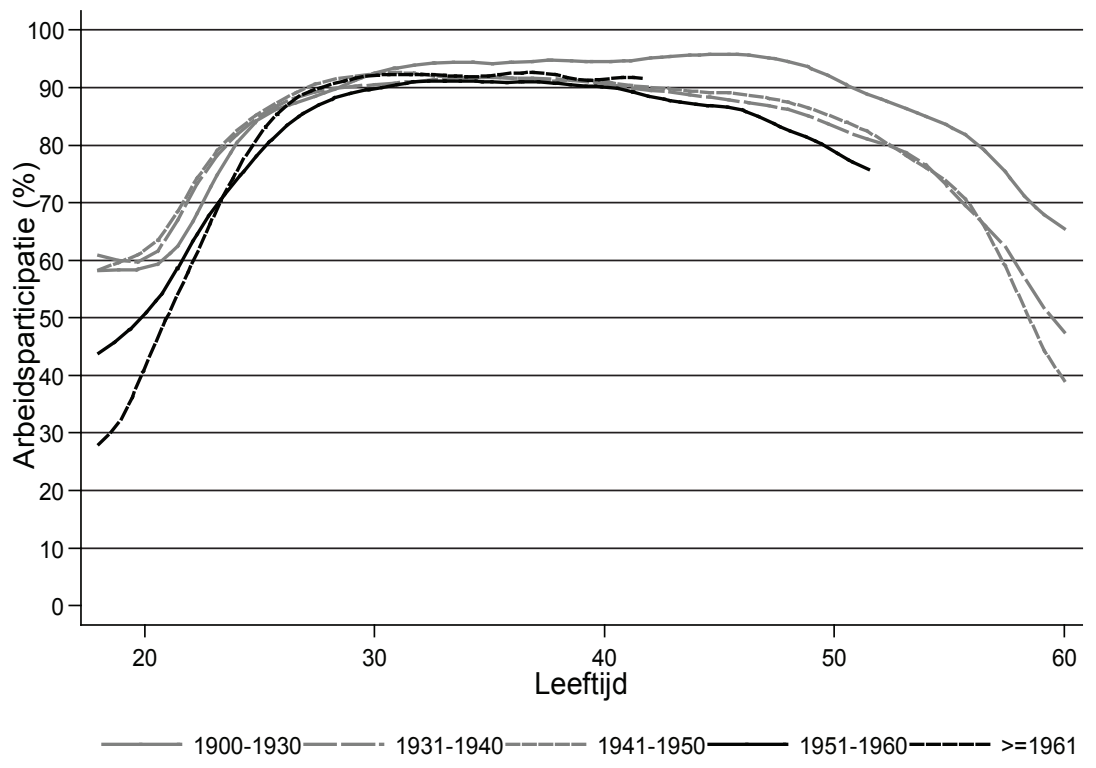

Bron: Family Survey of the Dutch Population

26. Een dip in de participatie als gevolg van het krijgen van kinderen is bij mannen niet te zien. 
Figuur 4.2

Arbeidsaanbod van vrouwen over de levensloop naar geboortecohort

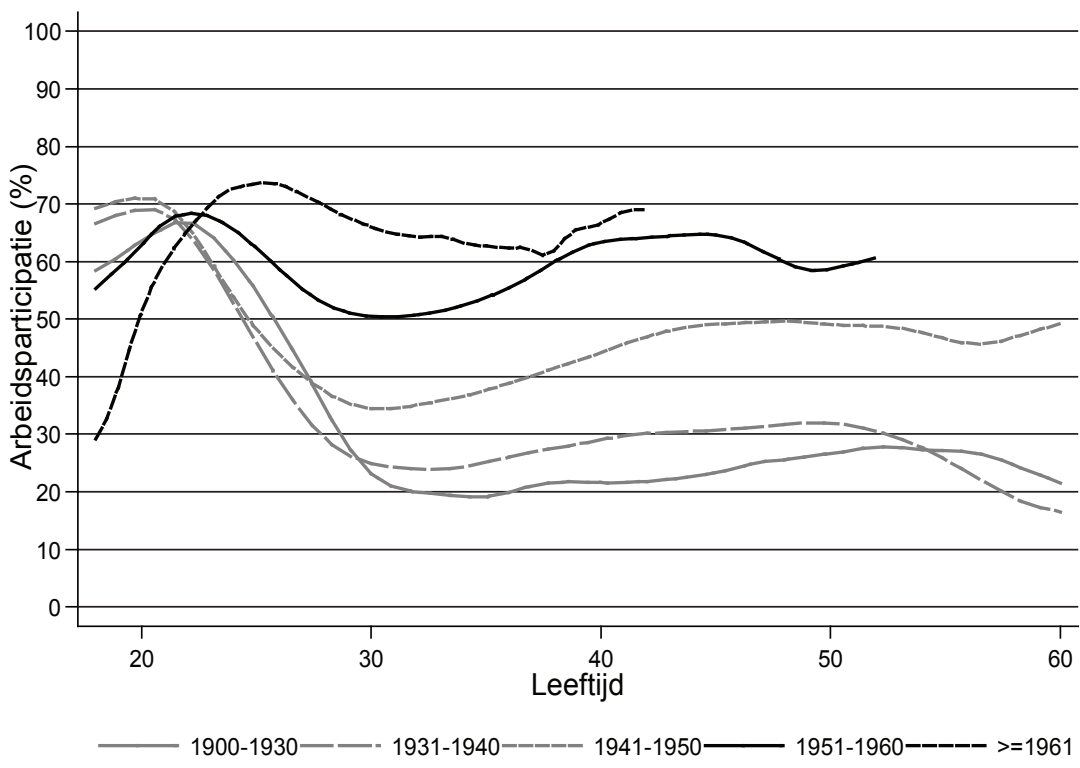

Bron: Family Survey of the Dutch Population

Dat de daling in de arbeidsparticipatie van vrouwen gerelateerd is aan het krijgen van kinderen blijkt uit figuur 4.3. In de figuur staat de arbeidsparticipatie van vrouwen afgebeeld in de periode van twee jaar voor het krijgen van het eerste kind tot 20 jaar daarna. Daaruit blijkt dat er sprake is van een daling van de arbeidsparticipatie rond de geboorte van het eerste kind. In de jaren daarna vindt er geen herstel van de participatie plaats als gevolg van de geboorte van andere kinderen (zie Fouarge e.a., 20IO). De verschillen naar geboorte cohort zijn echter groot. Vooral bij de twee oudste geboortecohorten is het patroon van participatie in de twintig jaar na de geboorte van het eerste kind vlak. Ook blijkt dat bij de jongere cohorten steeds minder sprake is van een daling van de arbeidsparticipatie twee jaar voor de geboorte van het eerste kind. Bij het jongste cohort vrouwen is dit anticipatieeffect vrijwel geheel verdwenen. Dit cohort trekt zich duidelijk niet meer van de arbeidsmarkt terug op het moment van hun huwelijk. De vrouwen die stoppen met werken doen dit pas een paar maanden voor de geboorte van hun eerste kind, maar er zijn duidelijk minder moeders die stoppen met betaalde arbeid. Het patroon voor de cohort van vrouwen geboren na 197I is overigens vergelijkbaar met dat van vouwen geboren tussen 196I en 1970. ${ }^{27}$ Voor het geboortecohort 195I-I960, was 80\% van de moeders twee jaar voor de geboorte van het eerste kind nog werkzaam, terwijl 60\% 20 jaar na de geboorte van het eerste kind nog steeds werkzaam is. Deze gegevens laten zien dat er zich

27. De cohort I97I is niet in het grafiek opgenomen omdat de observatieperiode na de geboorte van het eerste kind relatief kort is. 
ingrijpende gedragsveranderingen hebben voorgedaan bij opeenvolgende cohorten van vrouwen in Nederland (zie ook Bosch e.a., 20IO). Dit gedragsveranderingen kan het gevolg zijn van veranderingen in preferenties van vrouwen of van veranderingen in instituties en arbeidstijarrangementen die het mogelijk maken om arbeid en zorg beter te combineren.

\section{Figuur 4.3}

Arbeidsparticipatie van 2 jaar voor tot 20 jaar na de geboorte van het eerste kind, naar geboortecohort van de moeder

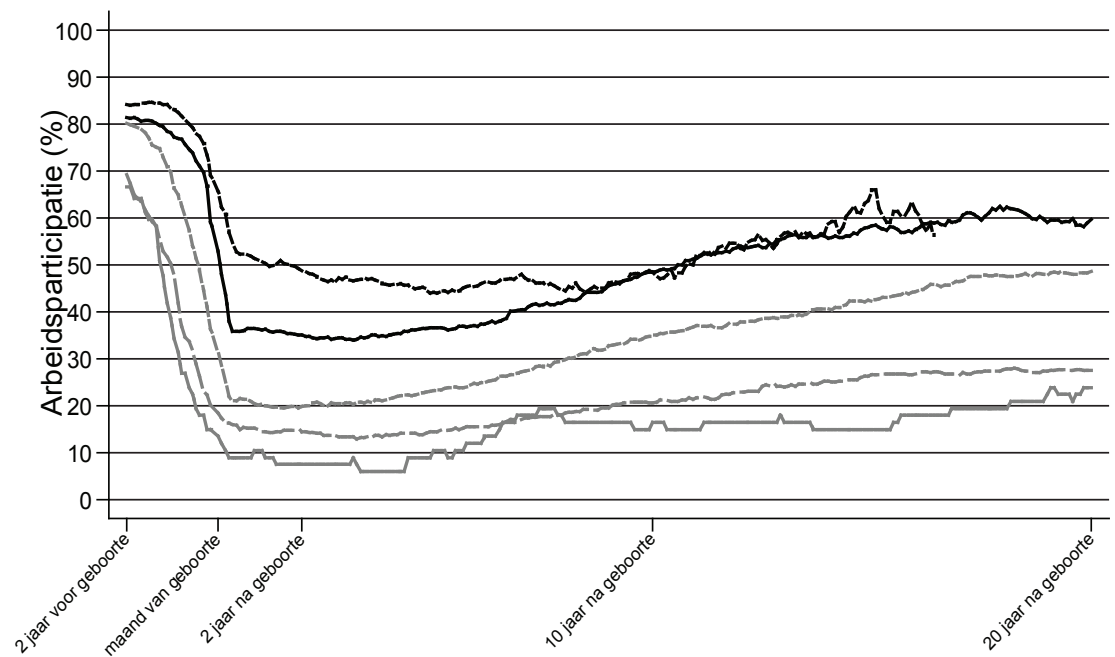

Tijd rond geboorte eerste kind

— 1900-1930——- 1931-1940-ー-ー- 1941-1950— 1951-1960-ーーーー >=1961

Bron: Family Survey of the Dutch Population

Het patroon van participatie rond de geboorte van het eerste kind voor de jongste cohort vrouwen (geboren in 196I of later) maskeert grote verschillen naar opleidingsniveau, zoals blijkt uit figuur 4.4. In die figuur staat de participatie van vrouwen uit die cohort afgebeeld, naar hoogst behaalde opleidingsniveau. Naarmate het opleidingsniveau van de moeder hoger is, is de dip in participatie kleiner. Bij moeders met een vbo/mavo diploma daalt de participatie van $65 \%$ vlak voor de geboorte van het eerste kind tot rond de $35 \%$ in de jaren na de geboorte. Bij de hoogst opgeleide vrouwen daalt de participatie van $90 \%$ in het jaar voor de geboorte geleidelijk tot ongeveer $60 \% 5$ jaar na de geboorte, om vervolgens weer te stijgen tot $70 \%$ Io jaar na de geboorte van het eerste kind. 


\section{Figuur 4.4}

Arbeidsparticipatie van 2 jaar voor tot 10 jaar na de geboorte van het eerste kind voor vrouwen geboren in 1961 of later, naar opleidingsniveau'

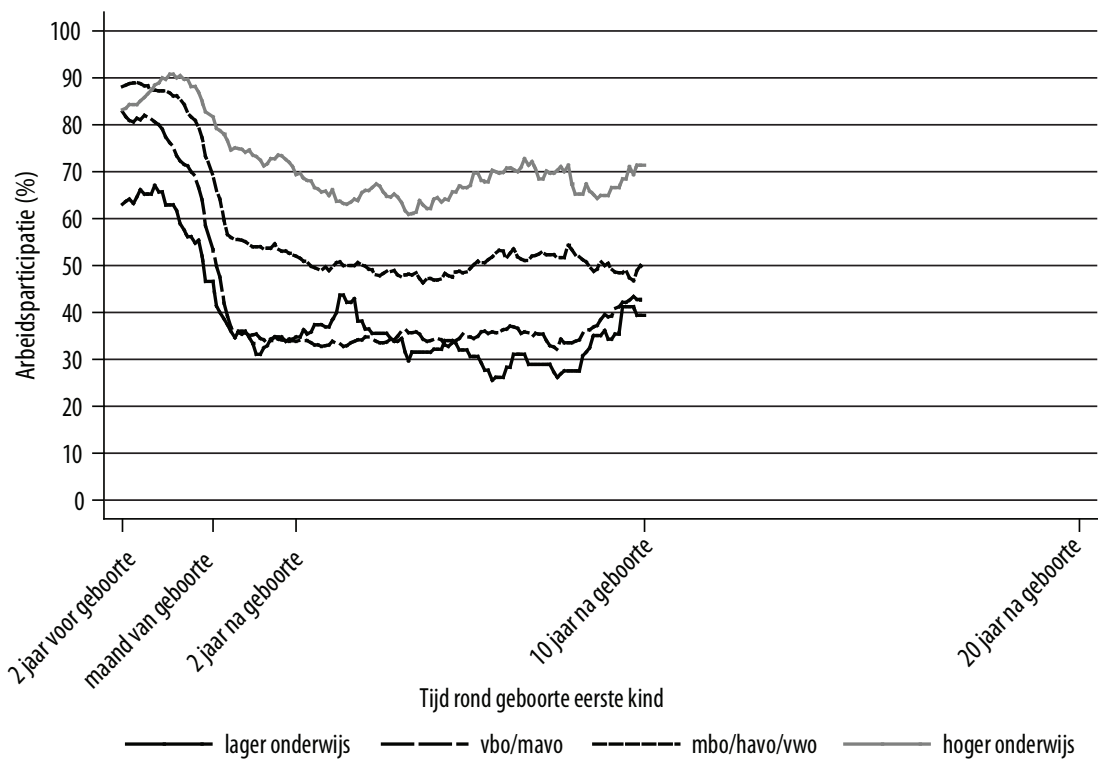

Bron: Family Survey of the Dutch Population

1 In verband met het aantal waarnemingen is de periode na de geboorte beperkt to 10 jaar. De schaal voor de figuur is gelijk gehouden aan dat van figuur 4.3 in verband met de vergelijkbaarheid.

\section{Modelschattingen: duuranalyse}

Aan de hand van een duurmodel kan worden onderzocht of periodes van inactiviteit nadelig zijn voor de arbeidsmarktparticipatie later in de loopbaan, hetgeen zou wijzen op depreciatie van menselijk kapitaal. In dit duurmodel is de kans op uitreden uit de toestand van inactiviteit gemodelleerd rekening houdend met de duur van de periode van inactiviteit (in logaritme ${ }^{28}$ en andere achtergrondkenmerken zoals het geboortecohort, opleidingsniveau en de burgerlijke staat. Daarnaast zijn enkele kenmerken uit het oude beroep meegenomen: een dummy variabele voor werk in deeltijd, het beroepsniveau (ISEI), en het percentage vrouwen in het beroep. Omdat een negatieve relatie tussen de kans op uitstroom uit inactiviteit wegens zorgtaken en de duur van de periode van inactiviteit het gevolg zou kunnen zijn van niet-waargenomen heterogeneiteit (dat wil zeggen specifieke kenmerken van de persoon die door de onderzoeker niet waargenomen zijn, zoals bijvoorbeeld motivatie en bekwaamheid), zijn twee versies van het model geschat: een model waar geen rekening wordt gehouden met niet-waargenomen heterogeneiteit, en een waar dit wel wordt gedaan. ${ }^{29}$

28. Wij gaan dus uit van Weibull verdeelde duurafhankelijkheid.

29. Wij schatten een 'linear probability model' met fixed effects. 
Omdat de frequentie loopbaanonderbrekingen wegens zorgtaken bij mannen laag is zijn de modellen voor alleen voor vrouwen geschat. Gelet op onze focus op depreciatie van menselijk kapitaal zijn alleen personen in de analyses meegenomen die gewerkt hebben voordat zij inactief werden. De multivariate analyses zijn uitgevoerd voor personen jonger dan 55 jaar, dit om het effect van vervroegde arbeidsmarktuittrede zo veel mogelijk uit te sluiten.

\section{Tabel 4.1}

Parameters uit duurmodel voor kans op uitstroom uit inactiviteit wegens de zorg voor kinderen (vrouwen)'

\begin{tabular}{lc}
\hline Duur in inactiviteit (in log) & Coëfficiënten \\
\hline Deeltijd in vorige baan & $-0,053^{* *}$ \\
\hline Leeftijd jongste kind (ref: 4-12 jaar) & $(0,026)$ \\
\hline -3 jaar & $-0,379^{* * *}$ \\
\hline 13 jaar of ouder & $(0,075)$ \\
\hline ISEl van vorige baan & $-0,069$ \\
\hline Rercentage women in occupation & $(0,089)$ \\
\hline R-kwadraat(adjusted) & $-0,276^{*}$ \\
\hline${ }^{2}$ & $(0,141)$ \\
\hline
\end{tabular}

Standaardfout tussen haakjes

${ }^{*} \mathrm{p}<0,10 * * \mathrm{p}<0,05$ *** $\mathrm{p}<0,01$

1 Overige controle variabelen: opleidingsniveau, geboorte cohort, burgerlijke staat

2 Deel van de totale variantie dat toe te schrijven is aan niet waarneembare verschillen tussen personen.

Bron: Family Survey of the Dutch Population

De schattingen uit de duurmodellen zijn opgenomen in tabel 4.I. Daaruit blijkt dat er sprake is van negatieve duurafhankelijkheid: men stroomt minder gemakkelijk uit inactiviteit wegens zorgtaken, naarmate men langer inactief is geweest. Een Io\% lagere duur van inactiviteit leidt tot een $0,5 \%$ lagere kans op uitstroom. ${ }^{30}$ Omdat de gemid-

30. Deze duurafhankelijkheid is veel kleiner dan in een model waar geen rekening gehouden wordt met niet-waargenomen heterogeneiteit. In dat model wordt de coëfficiënt van de duur van inactiviteit wegens zorgtaken geschat op O,I74 (significant op I\%). 
delde duur van inactiviteit wegens zorgtaken betrekkelijk lang is (gemiddeld genomen II6 maanden) is dit effect groot te noemen.

Tabel 4.I laat nog enkele andere interessante bevindingen zien. Zo blijken vrouwen die vroeger een deeltijdbaan hadden een kleinere kans op uitstroom uit inactiviteit te hebben vergeleken met vrouwen met een voltijdbaan. De mate van feminisering van het beroep waarin mannen of vrouwen werkzaam waren voor de periode van inactiviteit (gemeten door het percentage vrouwen in dat beroep), heeft weliswaar een positief effect op de kans op uitstroom uit inactiviteit - hetgeen zou betekenen dat het gemakkelijker is om weer aansluiting te vinden met de arbeidsmarkt wanneer men in een beroep met veel vrouwen werkt (Görlich en De Grip, 2009) - maar dit effect is klein en niet significant. De leeftijd van het jongste kind blijkt ook bepalend te zijn voor de kans op herintrede. Vrouwen met kinderen in de leeftijd van 4 tot en met I2 jaar hebben een grotere kans op uitstroom uit inactiviteit wegen zorgtaken. Dit heeft te maken met het feit dat kinderen in deze leeftijdgroep naar de lagere school gaan, waardoor de mogelijkheden voor vrouwen om te werken ruimer zijn. Vrouwen met oudere of jongeren kinderen hebben een kleinere op uitstroom uit inactiviteit wegen zorgtaken, al is bij de laatste groep dit effect niet significant.

\subsection{Beroepsniveau en loopbaanonderbrekingen}

Om het effect van loopbaanonderbrekingen wegens zorgtaken en de duur daarvan op het beroepsniveau vast te stellen zijn kleinste kwadraat regressies geschat. Daarbij is het beroepsniveau in de baan die volgt op de periode van inactiviteit geregresseerd op de duur van de laatste periode van inactiviteit (gemeten als het logaritme van het aantal maanden), de arbeidsmarktervaring (gemeten als het logaritme van het aantal maanden), het beroepsniveau in de oude baan, het aantal gewerkte uren in de oude baan (dummy variabele voor deeltijd werk), de mate van feminisering van het oude beroep ('mannenberoepen' 0-25\% vrouwen; gemengde beroepen $26-74 \%$ vrouwen; 'vrouwenberoepen' 75 -IOO\% vrouwen). Daarnaast controleert het model voor achtergrondkenmerken zoals opleidingsniveau, geboortecohort, en burgerlijke staat.

Tabel 4.2 rapporteert de uitkomsten van de modelschatting voor vrouwen. Wij vinden een negatief effect van de duur van inactiviteit op het beroepsniveau. Voor vrouwen die werkzaam waren in een gemengd beroep leidt een IO\% toename van de duur van inactiviteit tot een afname van het beroepsniveau met o,33\%. Hier lijkt dus sprake te zijn van depreciatie van menselijk kapitaal. De opgedane werkervaring voor de onderbreking blijkt het negatieve effect van de loopbaanonderbreking wegens zorgtaken te compenseren: een IO\% langere arbeidsmarktervaring leidt tot een $0,35 \%$ hoger beroepsniveau. Vrouwen die voor hun loopbaanonderbreking werkzaam waren in mannenberoepen en vrouwen in vrouwenberoepen hebben na hun loopbaanonderbreking een lager beroepsniveau dan vrouwen die werkzaam waren in gemengde beroepen. Dit lijkt er op te wijzen dat de gemengde beroepen vrouwen meer perspec- 
tief bieden om na hun loopbaanonderbreking vanwege de zorg voor hun kinderen een functie op niveau te vinden dan de meer homogene mannen- en vrouwenberoepen.

\section{Tabel 4.2}

Effect van loopbaanonderbrekingen wegens het kinderen krijgen op het beroepsniveau (log) na de onderbreking (coëfficiënten uit OLS model)'

\begin{tabular}{|c|c|}
\hline & Coëfficiënten \\
\hline \multirow[t]{2}{*}{ ISEl van vorige baan (log) } & $0,476^{* * *}$ \\
\hline & $(0,041)$ \\
\hline \multirow[t]{2}{*}{ Duur in inactiviteit (log maanden) } & $-0,033^{* * *}$ \\
\hline & $(0,010)$ \\
\hline \multirow[t]{2}{*}{ Aantal periods van inactiviteit } & $-0,012$ \\
\hline & $(0,020)$ \\
\hline \multirow[t]{2}{*}{ Arbeidsmarkt ervaring (log maanden) } & $0,035^{* * *}$ \\
\hline & $(0,013)$ \\
\hline \multirow[t]{2}{*}{ Deeltijd in vorige baan } & $-0,031$ \\
\hline & $(0,019)$ \\
\hline \multirow[t]{2}{*}{ Mannenberoep (ref: gemengde beroep) } & $-0,208^{*}$ \\
\hline & $(0,113)$ \\
\hline \multirow[t]{2}{*}{ Vrouwenberoep } & $-0,102^{*}$ \\
\hline & $(0,061)$ \\
\hline \multirow[t]{2}{*}{ Mannenberoep * Duur in inactiviteit } & 0,045 \\
\hline & $(0,031)$ \\
\hline \multirow[t]{2}{*}{ Vrouwenberoep * Duur in inactiviteit } & 0,017 \\
\hline & $(0,015)$ \\
\hline \multirow[t]{2}{*}{ Constante } & $1,786^{* * *}$ \\
\hline & $(0,163)$ \\
\hline R-kwadraat(adjusted) & 0,366 \\
\hline $\mathrm{N}^{*} \mathrm{~T}$ & 1212 \\
\hline N & 1093 \\
\hline
\end{tabular}

Standaardfout tussen haakjes

${ }^{*} p<0,10 * * 0<0,05 * * * 0,01$

' Overige controle variabelen: opleidingsniveau, geboorte cohort, burgerlijke staat

Bron: Family Survey of the Dutch Population 


\subsection{Conclusie}

In dit hoofdstuk zijn wij ingegaan op het effect van perioden van inactiviteit vanwege zorgtaken op de participatiekans en het beroepsniveau later in de loopbaan. Daarbij is gebruik gemaakt van de Family Survey of the Dutch Population die unieke retrospectieve informatie bevat over de demografische geschiedenis en arbeidsmarktloopbaan.

De data laten zien dat er zich in de afgelopen Ioo jaar substantiële verschuivingen hebben voorgedaan in de arbeidsparticipatie van vrouwen, terwijl er bij mannen niet veel is veranderd. Vrouwen trekken zich terug uit de sfeer van betaalde arbeid rond het moment dat zij kinderen krijgen, maar jongere cohorten vrouwen doen dit veel minder vaak en ook minder vroeg voor het krijgen van het eerste kind. Toch is de participatiedip rond het krijgen van kinderen bij vrouwen nog steeds substantieel en het zou kunnen leiden tot verlies van menselijk kapitaal dat zich manifesteert door een lagere baankans na de loopbaanonderbreking of door een lager beroepsniveau na uitstroom uit inactiviteit.

De analyses hebben laten zien dat er sprake is van een negatieve duurafhankelijkheid tussen de periode van inactiviteit wegens zorgtaken en de kans op uitstroom naar betaalde arbeid: wie lager inactief is, komt minder snel aan een baan. Onze gegevens laten ook zien dat een langere duur van inactiviteit resulteert in een lager beroepsniveau bij herintreding op de arbeidsmarkt. Dit negatieve effect wordt echter gecompenseerd door de opgebouwde arbeidsmarktervaring in de jaren voor de loopbaanonderbreking. Voor beleid is dit een interessante bevinding, omdat het suggereert dat de vaardigheden die opgedaan zijn in de vorige baan niet geheel verloren gaan indien vrouwen zich voor een al dan niet langere tijd terugtrekken uit betaalde arbeid om voor hun kinderen te zorgen. Opmerkelijk is wel dat wanneer vrouwen voor hun loopbaanonderbreking in verband met de zorg voor kinderen werkzaam waren in een specifiek mannen- of vrouwenberoep, zij minder perspectief hebben om na hun loopbaanonderbreking weer een functie op niveau te vinden dan wanneer ze eerder in een gemengd beroep werkzaam waren. De depreciatievoet van menselijk kapitaal is niet verschillend voor gemengde, mannen- en vrouwenberoepen. 



\section{Effect van werkloosheid op depreciatie van menselijk kapitaal}

\section{$5.1 \quad$ Inleiding ${ }^{31}$}

Er bestaat een rijke literatuur waarin ingegaan wordt op de effecten van werkloosheid op de verdere loopbaan van werknemers. In deze literatuur komen zowel de participatiekans na werkloosheid als het loon na werkloosheid aan bod. Deze literatuur is reeds in hoofdstuk 2 aan bod gekomen. Bezien Vanuit het perspectief van de menselijk kapitaal theorie gaat werkloosheid gepaard met een periode waarin het menselijk kapitaal niet gebruikt wordt, waardoor kennis en vaardigheden aan waarde verminderen - wat vervolgens resulteert in lagere participatiekansen en een lager loon na werkloosheid (Pissarides, 1992). Een alternatieve verklaring voor de lagere participatiekans en het lagere loon na werkloosheid is echter dat er een signaalfunctie uitgaat van werkloosheid (Albrechts e.a., I999): de kans op werkloosheid is selectief waardoor de minst productieve werknemers meer kans hebben om werkloos te worden. Potentiële nieuwe werkgevers reageren hierop door deze werknemers een lager loon te bieden dan werknemers met evenveel ervaring die niet werkloos zijn geweest.

Dit probleem van selectiviteit in de kans op werkloosheid is in de literatuur methodologisch 'opgelost' door gebruik van de 'control function' methode (Heckman en Robb, 1985) of instrumentele variabele (Gregg en Tominey, 2005). Daarbij probeert men te controleren voor de selectiviteit in de kans op werkloosheid. Het probleem hierbij is dat men afhankelijk is van de aanwezigheid van goede instrumenten in de data die de kans op werkloosheid verklaren maar niet samenhangen met de uitkomstvariabele zoals de latere participatiekans en het latere loon. Hierbij blijft het onzeker of de gebruikte variabelen voor het identificeren van zelfselectie hun werk inderdaad goed doen.

De 'state of the art' in de economische literatuur is dan ook om gebruik te maken van data rond 'displaced workers' (ontslagenen door massaontslag of faillissementen) om het echte effect van werkloosheid op de participatiekans en het loon te schatten (Kletzer, 1998; Kriechel, 2003; Koeber en Wright, 2006; Song, 2009). Deze literatuur is in hoofdstuk 2 aan de orde geweest. De reden voor de focus op ontslagwerklozen is

3I. Dit deel van het onderzoek is tot stand gekomen met de medewerking van Ruben van Gaalen (CBS) in het kader van de CBS/ROA samenwerkingsproject "Scholing en mobiliteit". 
dat - volgens de literatuur - bij collectief ontslag geen sprake is van eigen schuld van de ontslagene (Kriechel, 20Io), en deze vorm van werkloosheid veel weg heeft van een natuurlijk experiment waarin iemand 'bij toeval' werkloos is geworden. Hierdoor ziet de nieuwe werkgever de werkloosheid niet als signaal voor een lage productiviteit. In dit hoofdstuk sluiten wij aan bij deze literatuur en presenteren cijfers over de gevolgen van ontslagwerkloosheid voor participatiekans en loon na werkloosheid. De analyses zijn uitgevoerd met behulp van het Sociaal Statistisch Bestand (SSB) van het CBS, dat recentelijk is uitgebreid met informatie over ontslag om bedrijfseconomische redenen (Van Gaalen en Van Rooijen, 2009).

Ten opzichte van eerdere Nederlandse studies naar ontslag om bedrijfseconomische redenen ligt de bijdrage van dit hoofdstuk op een tweetal punten. Ten eerste, onze data betreft een integrale meting van alle ontslagen om bedrijfseconomische reden terwijl eerder studies zich hebben moeten beperken tot het enige tot nog toe beschikbaar grootschalig bestand rond het faillissement van Fokker in 1996 (Kriechel, 2003; Kriechel en Pfann, 2005). Ten tweede, onze data maken het mogelijk om een onderscheid te maken naar drie soorten ontslag om bedrijfseconomische redenen (faillissement, UWV ontslag aanvragen en collectieve uitstroom) terwijl eerdere studies zich hebben moeten beperken tot het faillissement van één bedrijf (Kriechel, 2003), collectieve uitstroom (Scheele e.a., 2008), of collectieve uitstroom en UWV ontslagaanvragen (Van Gaalen en Van Rooijen, 2009). Dit laatste punt is van belang omdat het ons de mogelijkheid beidt om voor elke vorm van bedrijfeconomisch ontslag na te gaan in welke mate de achtergrond kenmerken van de ontslagen (vóór het ontslag) het meest op die van de niet-ontslagenen lijken.

Dit hoofdstuk is als volgt opgebouwd. In paragraaf 5.2 geven wij een beschrijving van de in dit onderzoek gebruikte data. In paragraaf 5.3 bespreken wij de meest belangrijke voorlopige resultaten van het onderzoek. Daarbij zullen we ook ingaan op methodologische aspecten ten aanzien van de gebruikte data. In paragraaf 5.4 worden de belangrijkste conclusies van het onderzoek kort samengevat.

\subsection{Data}

We gebruiken registratiegegevens van de uitstroom van werknemers uit bedrijven zoals die opgenomen zijn in het Sociaal Statistisch Bestand (SSB) van het CBS. Het SSB is, anders dan de naam doet vermoeden, niet één enkel bestand. De definitieve versie ervan is een stelsel van koppelbare registers en enquêtes die onderling op elkaar zijn afgestemd en consistent zijn gemaakt (Arts, Bakker, \& Van Lith, 2000; Arts \& Hoogteijling, 2002; Bakker, 2002, 2009). Per jaargang worden inmiddels bijna 60 registers gebruikt. Daarnaast zijn ook gegevens uit enkele enquêtes in het SSB opgenomen. De demografische gegevens van het SSB (bijvoorbeeld geslacht, geboortedatum, geboorteland, burgerlijke staat en woonplaats) komen uit de gemeentelijke basisadministratie persoonsgegevens (GBA). 
Wat betreft bedrijfseconomisch ontslag maken we in onze analyse gebruik van de recent beschikbaar gekomen SSB gegevens over bedrijfseconomisch ontslag in Nederland (zie bijlage 2). In onze onderzoek maken we gebruik we drie vormen van bedrijfseconomisch ontslag in 2005:

- Ingewilligde individuele ontslagaanvragen wegens bedrijfseconomische redenen bij het UWV werkbedrijf;

- Baanbeëindigingen gevolgd door een faillissement;

- Collectieve ontslagen.

Om te bepalen in hoeverre ontslagenen om bedrijfseconomische redenen verschillen van niet-ontslagenen wordt een vergelijkingsroep geformeerd uit de populatie werknemers (ruim 6 miljoen personen) die het gehele jaar werknemer waren. Voor de analyses hebben we per persoon één record per maand in de periode 2003-2007, om op deze wijze iedere verandering in loon en participatie in beeld te brengen. Om de hoeveelheid data hanteerbaar te maken trekken we een gerandomiseerde steekproef van I0.000 werknemers: 6.083 niet-ontslagenen, I.879 ontslagenen via het UWV (bedrijfseconomisch), I.378 faillissementsontslagenen, en 660 collectief ontslagenen. De ontslagen werknemers worden gevolgd tot 2008 en vergeleken met niet-ontslagen werknemers. Het ijkpunt voor de ontslagenen is de ontslagmaand; voor de nietontslagenen is dit een willekeurige kalendermaand in 2005 .

Ten behoeve van dit onderzoek is gebruikmakend van het SSB opleidingsarchief het opleidingsniveau van de verschillende groepen ontslagenen bepaald. Het opleidingsarchief bevat het hoogst behaalde opleidingsniveau (eerste 2 digits SOI-code), voor zover bekend uit diverse jaargangen van registers en de Enquête Beroepsbevolking (EBB). Op basis daarvan kan een driedeling in het hoogst behaalde opleidingsniveau worden aangebracht (zie Kuijvenhoven \& Scholtus, 20IO):

- Laagopgeleiden: komt overeen met het niveau tot/met secundair onderwijs (eerste fase).

- Middelbaar opgeleid: komt overeen met secundair onderwijs (tweede fase).

- Hoogopgeleid: is hoger onderwijs (HBO/WO).

\subsection{Beschrijvende statistieken}

In welke mate zijn de kenmerken van de ontslagenen, voor het bedrijfseconomisch ontslag, vergelijkbaar met die van de niet-ontslagenen? Indien bedrijfseconomisch ontslag inderdaad een soort natuurlijk experiment is en dus verschillende werknemers op een willekeurige wijze treft, dan zouden de kenmerken van de ontslagenen moeten lijken op die van de niet-ontslagenen. Grote verschillen in kenmerken zouden duiden op een mogelijk probleem van selectie in werkloosheid. Daarom bestuderen wij eerst in deze paragraaf in welke mate de persoons- en baankenmerken van ontslagenen en niet-ontslagenen op elkaar lijken. 


\section{Relatie persoonskenmerken en ontslag}

Op basis van de verdelingen naar achtergrond kenmerken lijken de UWV-ontslagenen het meest op de niet-ontslagenen (tabel 5.I). Hieruit kan dus worden afgeleid dat endogene selectie in werkloosheid op basis van waarneembare kenmerken nagenoeg geen rol speelt voor UWV-ontslagenen. De effecten van werkloosheid op participatie en loon voor deze groep lenen zich dus goed voor een interpretatie in termen van depreciatie van menselijk kapitaal.

Opvallend is het hoge percentage jongeren onder de faillissementontslagenen en de relatief grote aandeel ouderen én jongeren in de groep collectief ontslagenen. Eveneens opvallend maar niet verassend is dat vooral de laag- maar ook middelbaar opgeleiden oververtegenwoordigd zijn binnen alle groepen ontslagenen. Van de groep niet-ontslagen personen die geheel 2005 werkzaam waren is $16 \%$ allochtoon. Het percentage allochtonen is binnen de groep ontslagen werknemers duidelijker hoger: gemiddeld $25 \%$. In het bijzonder de groep overig niet-westerse allochtonen wordt bovengemiddeld vaak met ontslag geconfronteerd. Dit verschil is deels terug te voeren op faillissementsontslag, waar deze groep allochtonen relatief vaak mee te maken heeft.

\section{Relatie baan- en bedrijfskenmerken en ontslag}

Het ijkpunt voor de ontslagenen is de ontslagmaand; voor de niet-ontslagenen is dit een willekeurige kalendermaand in 2005. De gemiddelde baanomvang op tijdstip $t=0$ voor de faillissementsontslagenen is relatief laag. Dit betreffen vaker dan gemiddeld kleine baantjes. De gemiddelde baanduur (niet in tabel) laat zien dat het met name kortdurende baantjes zijn. ${ }^{22}$ De collectief ontslagenen hebben het vaakst een betrekking in voltijd en is de baanduur relatief gezien het langst (gemiddeld ruim 8 jaar).

Wat betreft de bedrijfskenmerken valt op dat er in 2005 vooral banen binnen de zakelijke dienstverlening verloren gingen als gevolg van een faillissement (zie tabel 5.2). Dit gebeurt veel minder vaak in gezondheid- en welzijnsinstellingen. In de industrie en de sector handel/reparatie gaan relatief veel banen verloren die via de UWV route lopen. Collectief ontslag c.q. sociale plannen komen vaker voor in de publieke sector (Openbaar bestuur en Onderwijs).

Het is niet verassend dat de collectief ontslagenen voornamelijk in hele grote bedrijven werkzaam waren (tabel 5.I); dit was deel van het selectieproces voor de constructie van de data (zie paragraaf 5.2). Opvallend is wel dat het algemene bedrijvenregister

32. Opvallend is dat een klein percentage van de personen wiens baan werd beëindigd als gevolg van een faillissement vlak voordat het bedrijf failliet ging geen baan heeft. Dit heeft te maken met het feit dat de maandgegevens peildatumgegevens zijn, in dit geval op de derde vrijdag van iedere maand. Juist bij deze groep werknemers komt het voor dat de baan nog niet bestond op peildatum $t=-\mathrm{I}$ (één maand voor het ontslag) en niet meer bestond op $\mathrm{t}=\mathrm{O}$. 
(ABR), waar dit kenmerk op is gebaseerd, enige afwijking vertoont met het gemiddelde aantal banen dat in het SSB wordt waargenomen: een klein percentage van de collectief ontslagenen zou volgens de ABR in kleine bedrijven werkzaam zijn geweest. Administratieve vertraging is één oorzaak van deze discongruentie; het ABR geeft ook een jaarcijfer. Bedrijven die failliet gaan zijn vaak erg klein. Personen die via het UWV worden ontslagenen komen zowel uit grote als kleine, maar ook vaker dan gemiddeld uit kleine bedrijven.

\section{Tabel 5.1}

Samenstelling van groep ontslagenen en niet-ontslagenen naar achtergrondkenmerken (percentages)

$\begin{array}{lcccc} & \text { Geen ontslag } & \text { Faillissement } & \text { UWV } & \text { Collectief } \\ \text { Geboortejaar } & & & & \\ <=1945 & 3 & 3 & 3 & 9 \\ 1946-50 & 10 & 6 & 10 & 13 \\ 1951-55 & 11 & 7 & 12 & 7 \\ 1956-60 & 12 & 8 & 13 & 6 \\ 1961-65 & 14 & 10 & 14 & 8 \\ 1966-70 & 14 & 11 & 16 & 7 \\ >=1971 & 36 & 55 & 33 & 50\end{array}$

\section{Geslacht}

Mannen

55

67

56

61

\section{Opleidingsniveau}

Laag

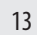

25

22

Middel

40

48

46

54

Hoog

47

27

32

32

Herkomstgroepering

$\begin{array}{lrrrr}\text { Autochtonen } & 84 & 74 & 81 & 83 \\ \text { Marokkanen/Turken } & 3 & 7 & 4 & 3 \\ \text { Surinamers/Antillianen } & 3 & 4 & 2 & 2 \\ \text { Overig Niet-Westers } & 2 & 5 & 4 & 3 \\ \text { Westers } & 8 & 11 & 9 & 9\end{array}$


HOOFDSTUK 5

Tabel 5.1 (vervolg)

Samenstelling van groep ontslagenen en niet-ontslagenen naar achtergrondkenmerken (percentages)

Geen ontslag Faillissement UWV Collectief

Baanomvang (maand $=0$ )

Geen baan

$0-20 \%$

$20-40 \%$

$40-60 \%$

$60-80 \%$

$80-100 \%$

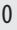

3

7

11

10

69
6

6

13

9

11

55
0

3

6

10

10

70

Fiscaal loon (maand=0)

Geen ink

$<=1000$

0

6

1001-2000

2001-3000

3001-4000

4001-5000

$>=5000$
19

40

19

7

8

6
20
29
10
5
5

0

17

23

19

17

9

16

$\begin{array}{lrrrr}\text { Grootteklasse (ABR) } & 1 & 6 & 1 & 0 \\ \text { Onbekend } & 14 & 34 & 34 & 1 \\ <10 \text { werknemers } & 17 & 30 & 24 & 2 \\ 10-49 \text { werknemers } & 8 & 12 & 7 & 1 \\ 50-99 \text { werknemers } & 19 & 12 & 14 & 12 \\ 100-499 \text { werknemers } & 41 & 6 & 20 & 84 \\ >=500 \text { werknemers } & & & \end{array}$


Tabel 5.2

Samenstelling van groep ontslagenen en niet-ontslagenen naar sector van activiteit (percentages)

\begin{tabular}{lcccc} 
& Geen ontslag & Faillissement & UWV & Collectief \\
\hline Landbouw, bosbouw, visserij & 1,6 & 1,0 & 2,6 & 0,0 \\
Delfstoffenwinning & 0,2 & 0,1 & 0,0 & 0,3 \\
Industrie & 13,4 & 13,1 & 20,8 & 7,7 \\
Energie- en waterschappen & 0,4 & 0,2 & 0,1 & 2,1 \\
Bouwnijverheid & 5,1 & 7,7 & 9,1 & 0,5 \\
Handel en reparatie & 16,0 & 15,0 & 25,4 & 22,6 \\
\hline Horeca & 2,9 & 6,2 & 3,9 & 0,6 \\
Vervoer, opslag & 5,9 & 10,1 & 5,3 & 12,9 \\
Financiële instellingen & 4,0 & 3,1 & 1,0 & 0,0 \\
Zakelijke dienstverlening & 14,7 & 27,1 & 16,0 & 7,4 \\
Openbaar bestuur & 8,2 & 0,4 & 0,4 & 14,2 \\
Onderwijs & 6,8 & 2,0 & 0,9 & 20,8 \\
Gezondheids- en welzijn & 16,1 & 5,5 & 10,5 & 7,3 \\
Milieu, cultuur & 3,7 & 2,8 & 3,7 & 3,5 \\
Onbekend & 1,0 & 5,8 & 0,2 & 0,2 \\
Total & 100,0 & 100,0 & 100,0 \\
Bron: SSB & & & \\
\hline
\end{tabular}

\subsection{Participatie en loon voor en na ontslag}

In figuur 5.I wordt de gemiddelde participatie en het fiscaal loon maandelijks van 2003-2007 in beeld gebracht. In tegenstelling tot bij de beschrijvende cijfers beperken we de analyse in deze paragraaf tot degenen die na 1945 zijn geboren en sluiten wij de personen die na ontslag met pensioen gaan uit. Met name onder de werknemers die collectief stoppen met werken bevinden zich veel werknemers die met (pre)pensioen gaan (I8\%). De doorgetrokken dikke lijn laat zien welk percentage een baan als werknemer heeft (linkeras) en de doorgetrokken dunne lijn geeft het gemiddelde maandloon aan. De mate van spreiding wordt met de lijnen van het Ioe en het goe percentiel zichtbaar (rechteras). De maandloonlijnen worden alleen berekend voor de mensen die daadwerkelijk een baan hebben. Op deze manier wordt het eventuele niveau van de loondepreciatie zichtbaar. Kortom, het participatie effect van het bedrijfseconomisch ontslag wordt zichtbaar gemaakt aan de hand van de dikke lijn, terwijl het inkomenseffect zichtbaar gemaakt wordt aan de hand van de dunne lijnen. 
Figuur 5.1

Participatie en loonprofiel van 3 jaar voor ontslag tot 3 jaar na ontslag

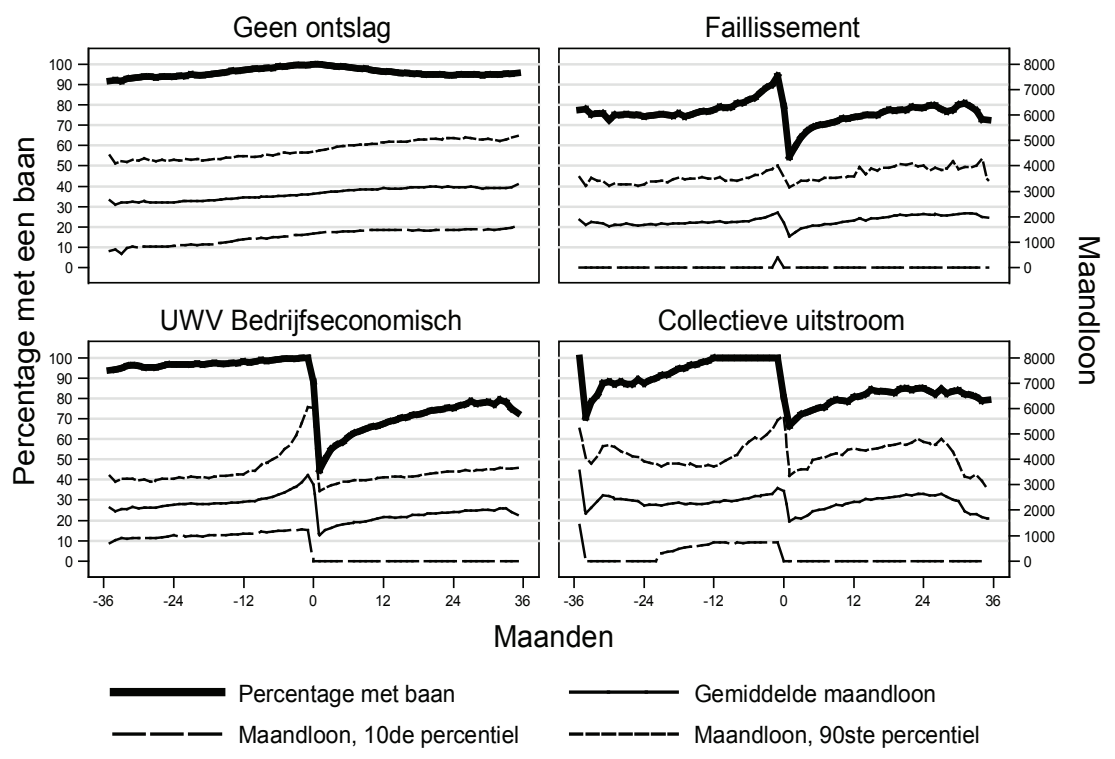

Bron: SSB

Een groot deel van de ontslagenen vindt direct aansluitend nieuw werk: de zwarte dikke lijn zakt scherp op $t=0$ maar niet verder dan $55 \%$ (faillissement), $45 \%$ (UWV) en $65 \%$ (collectief). Vervolgens stijgt het participatieniveau, maar het blijft om en nabij de $80 \%$ steken. Personen die met een collectieve regeling stoppen en niet met (pre) pensioen gaan doen het iets beter dan de andere ontslagenen.

Interessant is dat de lijn bij de faillissementsontslagenen licht stijgt vóór $\mathrm{t}=\mathrm{O}$. Dit hangt samen met de al genoemde selectiviteit van relatief veel zeer korte baantjes. Ook zien we dat de lijn de IO०\% niet haalt: dit heeft ook te maken met de eerdergenoemde peildatummeting.

Het fiscale loon neemt bij de niet-ontslagenen geleidelijk toe. Het gemiddelde salaris bij de ontslagenen ligt gedurende de gehele periode lager dan dat van de niet-ontslagenen. Verder stijgt het niet of in elk geval niet zo snel als in de vergelijkingsgroep.

Opmerkelijk is de sterke stijging van het loon vóór ontslag (behalve bij de faillissements-ontslagenen). Deze loonpiek heeft te maken met het feit dat mensen ontslagvergoedingen krijgen. Deze worden verdeeld over de kalendermaanden voor het ontslag (in het jaar van ontslag) wat leidt tot een hoger gemiddeld maandloon. 
Overigens is het opvallend dat de loonpiek vóór ontslag vooral te maken heeft met de toename van het loon van werknemers in het hoogste deciel van de loonverdeling. Het lijkt er dus op dat werknemers aan de onderkant van de loonverdeling geen ontslagvergoeding krijgen.

Het effect van ontslag op de arbeidsparticipatie van mannen is kleiner dan het effect op de arbeidsparticipatie van vrouwen (figuur 5.2). Het effect van ontslag op het loon doet zich voor bij zowel mannen als vrouwen: de loonontwikkeling blijft achter vergeleken met dat van werknemers die niet zijn ontslagen. Dit geldt ook voor de verschillen in opleidingsniveaus (figuur 5.3). Binnen de groep ontslagenen vinden hoog opgeleiden sneller weer een baan als werknemer dan laag opgeleiden. Overigens blijkt dat jongeren vooral wat betreft de baankans na ontslag beter herstellen dan ouderen (niet getoond in figuur).

\section{Figuur 5.2}

Participatie en loonprofiel van 3 jaar voor ontslag tot 3 jaar na ontslag, naar geslacht*

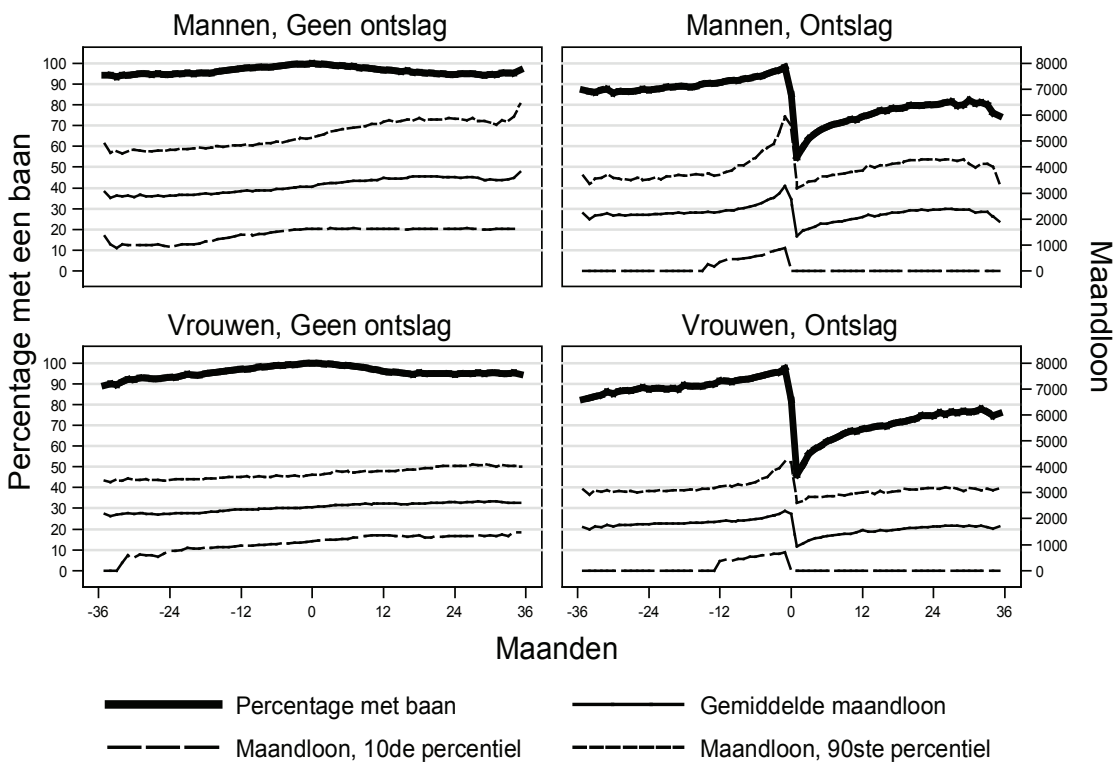

Bron: SSB

* In de figuur zijn de drie vormen van bedrijfseconomisch ontslag bij elkaar genomen 
Figuur 5.3

Participatie en loonprofiel van 3 jaar voor ontslag tot 3 jaar na ontslag, naar opleidingsniveau'

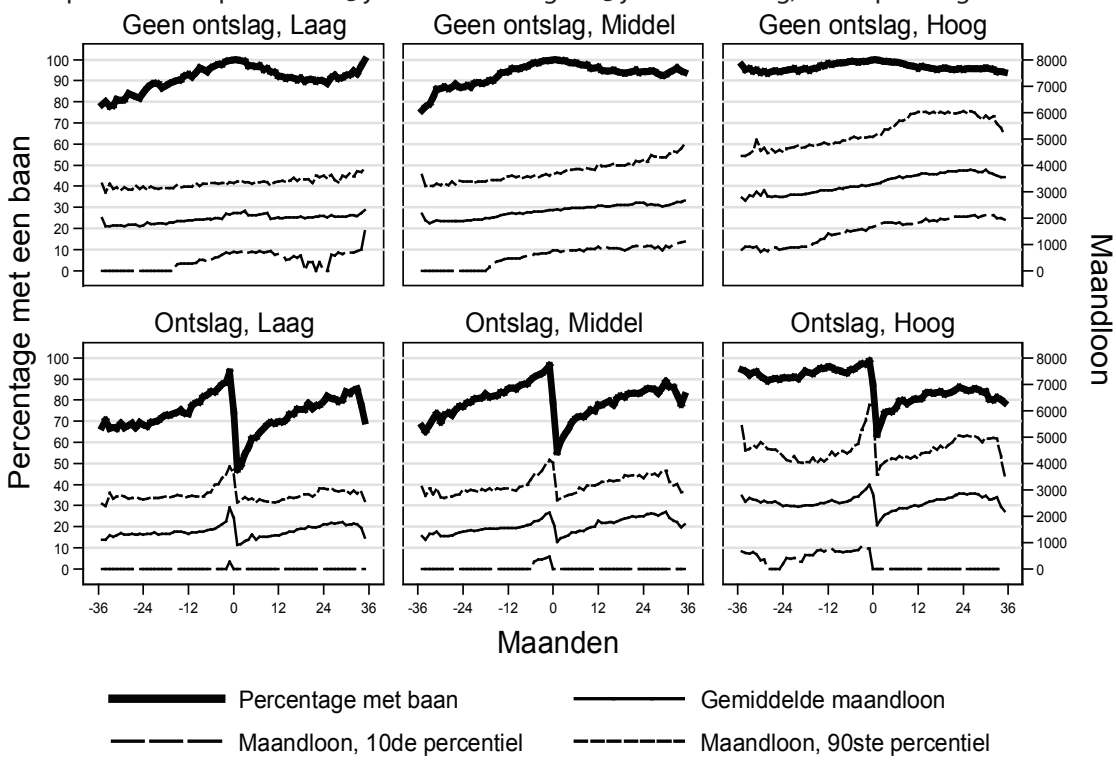

Bron: SSB

1 In de figuur zijn de drie vormen van bedrijfseconomisch ontslag bij elkaar genomen

Figuur 5.4 vergelijkt de loonontwikkeling van ontslagwerklozen voor en na het ontslag met de loonontwikkeling van niet-werklozen. Het is duidelijk dat het loon van ontslagwerklozen lager is dan het loon van de referentiegroep in de maanden voor ontslag. In onze analyses van het effect van werkloosheid op het loon na herintreding zullen wij daarom controleren voor het loon I2 maanden voor het ontslag.

Alleen voor de collectieve uitstroom en voor UWV ontslagwerklozen neemt het loon, overeenkomstig met de ontwikkeling in figuur 5.I, toe in de paar maanden voor ontslag. Hierdoor wordt voor de ontslagwerklozen in de maanden vlak voor het ontslag een hoger loon gemeten dan voor niet ontslagenen. Zoals eerder gezegd is dit een artefact van de data. $\mathrm{Al}$ met al kan op basis van de data worden vastgesteld dat het loonverschil tussen ontslagenen en niet-ontslagen groter is na het ontslag. Dit geldt althans voor werknemers die een bedrijfeconomisch ontslag via de UWV of een faillissement hebben meegemaakt. Voor de collectieve uitstroom geldt dat ontslagenen in de eerste 24 maanden na ontslag hun loonachterstand op niet-ontslagenen deels inlopen. 
Figuur 5.4

Verschil in maandloon tussen ontslagenen en niet-ontslagenen, naar soort bedrijfseconomisch ontslag (absolute verschillen)

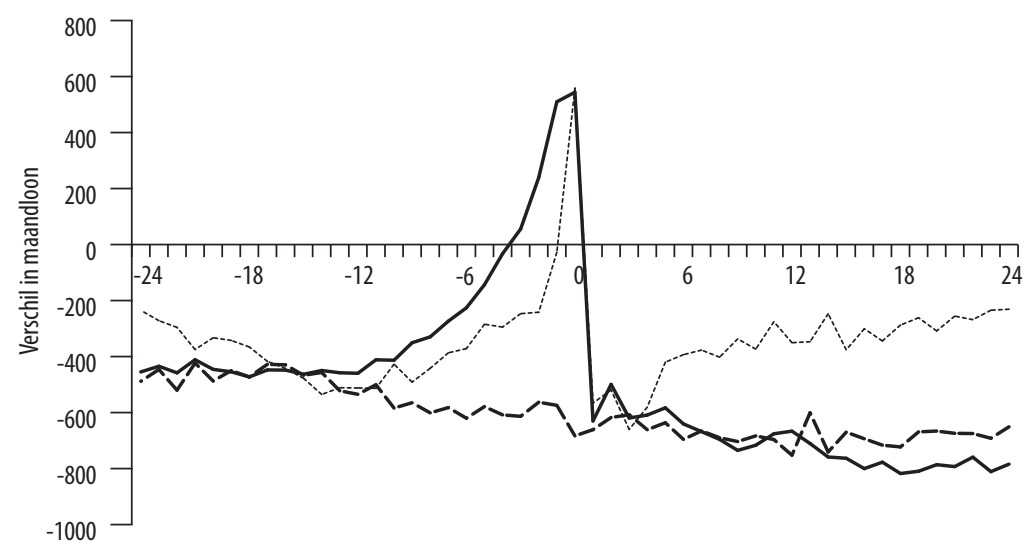

Maanden

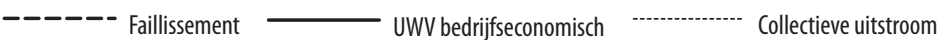

\subsection{Schattingsresultaten}

De kans op een baan en het loon na ontslag zijn natuurlijk niet alleen afhankelijk van het soort bedrijfseconomisch ontslag. Zo laten de gegevens in paragraaf 5.3 zien dat ontslagenen en niet-ontslagenen op een aantal achtergrondkenmerken verschillend zijn van elkaar, waarbij geldt dat UWV-ontslagenen het meest op de niet-ontslagenen lijken. Ook de kenmerken van personen in de verschillende vormen van bedrijfseconomisch ontslag verschillen enigszins onderling. Om die reden is het van belang om in multivariate analyses te controleren deze achtergrondkenmerken. Deze multivariate analyses zijn als volgt opgebouwd. Ten eerste kijken wij naar de kans op participatie een jaar na het bedrijfseconomisch ontslag en vergelijken wij deze kans met de participatiekans voor niet-ontslagenen. Ten tweede kijken wij naar het loon I2 maanden na ontslag. Ten slotte maken wij gebruik van een selectiemodel om het effect van bedrijfseconomisch ontslag op het loon 12 maanden na ontslag te bepalen, conditioneel op het feit dat de betreffende persoon weer een baan heeft gevonden. 
Tabel 5.3

Logit model voor de kans op participatie 12 maanden na ontslag (odds-ratio's)'

Model $1 \quad$ Model 2

\section{Soort ontslag}

Geen ontslag

Ref Ref

Faillissement

$0,09 * * *$

$0,14^{* * *}$

UWV bedrijfseconomisch

$0,08^{* * *}$

$0,14^{* * *}$

Collectief ontslag

$0,12^{* * *}$

$0,21^{* * *}$

\section{Geboorte jaar}

Geboren voor 1960

Ref

Ref

Geboren 1960-70

$1,60^{* * *}$

1,10

Geboren na 1970

$1,75^{* * *}$

1,28

\section{Etniciteit}

Autochtonen

Ref Ref

Westerse allochtoon

$0,71^{* *}$

0,71

Niet-westerse allochtoon

$0,45^{* * *}$

$0,52^{* * *}$

\section{Geslacht}

Vrouwen

Ref Ref

Mannen

$1,31^{* * *}$

1,21

Werkgelegenheidsgroei in sector (t-1)

$1,20^{* * *}$

$1,13^{* *}$

\section{Opleiding}

Opleiding laag

Ref Ref

Opleiding middel

$1,44^{*}$

Opleiding hoog

$1,55^{* *}$

$\begin{array}{lll}\text { Constante term } & 22,83^{* * *} & 14,81^{* * *} \\ \text { N } & 9375 & 3162 \\ \text { Pseudo R-kwadraat } & 0,19 & 0,14\end{array}$

${ }^{*} p<0,05 ;{ }^{* *} p<0,01 ;{ }^{* * *} p<0,001$

Bron: SSB

1 Odds-ratio's geven de relatie kans op arbeidsparticipatie weer. Een odds-ratio kleiner dan 1 betekent een kleinere kans op werk en correspondeert met een negatief regressie coëfficiënt. Een oddsratio groter dan 1 betekent een grotere kans op werk en correspondeert met een positief regressie coëfficiënt. 
Tabel 5.3 rapporteert de schattingsresultaten van een logit model met betrekking tot de kans op participatie I2 maanden na ontslag. De gepresenteerde cijfers zijn de odds-ratios. In model 2 wordt gecontroleerd voor het opleidingsniveau, terwijl dit in model I niet het geval is. Het opleidingsniveau kon voor slechts I/3 van de personen worden bepaald, meteen sterke reductie van het aantal cases tot gevolg. De bevindingen uit de beschrijvende analyses worden in tabel 5.3 bevestigd. De baankans na I2 maanden is significant lager voor ontslagenen dan voor niet-ontslagenen. Een vergelijking tussen model I en model 2 leert dat dit deels het gevolg is van onderliggende verschillen in opleidingsniveau, maar dat zelfs wanneer hiervoor gecontroleerd wordt het verschil in baankans significant is. De controlevariabelen wijzen de verwachte kant op: jongeren, mannen, autochtonen, hoogopgeleiden hebben vaker een baan. In het model wordt gecontroleerd voor de werkgelegenheidsontwikkeling voor de sector waarin men werkzaam was in de maand van ontslag. Dit is gedaan aan de hand van ROA prognoses voor de werkgelegenheidsontwikkeling (ROA, 2009). Werkt(e) iemand in een groeisector op tijdstip $t$-I (ijkpunt-I), dan vergroot dit de kans op een baan, I2 maanden later.

Tabel 5.4 rapporteert de schattingsresultaten van de loonvergelijking. Daarin wordt het loon van werkenden gerelateerd aan de vorm van het bedrijfseconomisch ontslaag, waarbij niet-ontslagenen de referentiegroep zijn. In model 4 wordt gecontroleerd voor het opleidingsniveau terwijl dit niet het geval is in model 3. In de analyses is ook gecontroleerd voor het feit of men van sector is veranderd. Dit wordt gedaan omdat eerdere studies hebben aangegeven dat bij sector veranderingen een deel van het sector specifieke menselijk kapitaal verloren gaat.

De gegevens in tabel 5.4 laten zien dat werkenden die slachtoffer zijn geweest van een faillissement of van UWV bedrijfseconomisch ontslag een significant lager loon verdienen I2 maanden na ontslag (ook al wordt gecontroleerd voor het loon I2 maanden voor ontslag); het effect van het ontslag bedraagt respectievelijk $9 \%$ en II\%. Bij collectief ontslag wordt in het model waarin gecontroleerd voor het opleidingsniveau, geen effect van ontslag op het loon gevonden. In tegenstelling tot de verwachting wordt in onze analyse geen significant effect van sectorverandering op het loon gevonden. 
Tabel 5.4

OLS schatting voor het loon 12 maanden na ontslag (in log) (regressie coëfficiënten)

$\begin{array}{lll} & \text { Model } 3 & \text { Model } 4 \\ \text { Geen ontslag } & \text { Ref } & \text { Ref } \\ \text { Faillissement } & -0,06^{* * *} & -0,09^{* *} \\ \text { UWV bedrijfseconomisch } & -0,11^{* * *} & -0,11^{* * *} \\ \text { Collectief ontslag } & 0,06^{* *} & 0,05\end{array}$

$\begin{array}{lll}\text { Geboren voor } 1960 & \text { Ref } & \text { Ref } \\ \text { Geboren 1960-70 } & 0,02 & 0,03 \\ \text { Geboren na } 1970 & -0,06^{* * *} & -0,15^{* * *}\end{array}$

$\begin{array}{lll}\text { Autochtonen } & \text { Ref } & \text { Ref } \\ \text { Westerse allochtoon } & 0,02 & 0,03 \\ \text { Niet-westerse allochtoon } & -0,10^{* * *} & -0,04\end{array}$

$\begin{array}{lll}\text { Vrouwen } & \text { Ref } & \text { Ref } \\ \text { Mannen } & 0,11^{* * *} & 0,13^{* * *}\end{array}$

\begin{tabular}{lll} 
Werkgelegenheidsgroei in sector (t-1) & $0,01^{* * *}$ & 0,01 \\
Werk in zelfde sector & Ref & Ref \\
Werk in andere sector & 0,00 & $-0,02$ \\
Werk in andere sector ${ }^{*}$ ontslag & 0,00 & 0,00 \\
\hline Loon in t-12 (in log) & & $0,56^{* * *}$ \\
\hline
\end{tabular}

\begin{tabular}{|c|c|c|}
\hline Opleiding laag & Ref & Ref \\
\hline Opleiding middel & & $0,11^{* * *}$ \\
\hline Opleiding hoog & & $0,31^{* * *}$ \\
\hline
\end{tabular}

$\begin{array}{lll}\text { Constante term } & 3,51^{* * *} & 4,24^{* * *} \\ \text { N } & 7771 & 2598 \\ \text { R-kwadraat } & 0,47 & 0,52 \\ { }^{*} \mathrm{p}<0,05 ;{ }^{* *} \mathrm{p}<0,01 ;{ }^{* * *} \mathrm{p}<0,001 & & \\ \text { Bron: SSB } & & \end{array}$

In de analyses van tabel 5.4 zou er sprake kunnen zijn van selectiviteit. Immers, vooral de meest kansrijke werklozen wegen bedrijfseconomisch ontslag zullen er in slagen een 
baan te vinden, hetgeen tot een onderschatting ven het effect van ontslagwerkloosheid op het loon zou kunnen leiden. In tabel 5.5 worden de resultaten van een Heckman selectiemodel gepresenteerd, waarbij de loonvergelijking en de kans op betaalde arbeid simultaan zijn geschat. ${ }^{33}$ De significante selectieterm $(\lambda)$ in de loonvergelijking suggereert dat er inderdaad sprake van een selectie-effect. Het geschat effect van ontslagwerkloosheid op het loon is als volgt: ontslagenen door faillissement verdienen $7 \%$ minder loon, en UWV-ontslagenen $13 \%$ minder loon. Dat het effect van werkloosheid kleiner is bij faillissement dan bij ontslag via de UWV zou het gevolg kunnen zijn van het feit dat faillissementontslagenen gemiddeld genomen jonger zijn (in ons model controleren wij alleen voor de geboortejaar door middel van twee dummy variabelen), en dat zij voor het ontslag een lager loon verdienen waardoor een bodem effect zou kunnen spelen. Voor de collectief ontslagenen wordt echter een positief looneffect van $5 \%$ gevonden. Enerzijds kan dit er op wijzen dat collectief ontslag een gunstig effect heeft op de allocatie van arbeid. Anderzijds kan dit positief effect het gevolg zijn van het feit dat bij de groep collectieve ontslageren ook werknemers zitten die vrijwillig het bedrijf verlaten, mogelijk voor een betere baan elders.

Tabel 5.5

Heckman selectiemodel voor het loon in t+12 (in log) (regressie coëfficiënten)

\section{Model 5}

\begin{tabular}{ll} 
Loon & Ref \\
Geen ontslag & $-0,07^{* * *}$ \\
Faillissement & $-0,13^{* * *}$ \\
UWV bedrijfseconomisch & $0,05^{*}$ \\
Collectief ontslag & \\
\hline Geboren voor 1960 & Ref \\
Geboren 1960-70 & 0,02 \\
Geboren na 1970 & $-0,06^{* * *}$ \\
& \\
Autochtonen & Ref \\
Westerse allochtoon & 0,02 \\
Niet-westerse allochtoon & $-0,10^{* * *}$ \\
Vrouwen & \\
Mannen & Ref \\
\hline
\end{tabular}

33. Een Heckman selectiemodel (Heckman, 1979) wordt hier toegepast om rekening te houden met het feit dat het deel van de waarnemingen waarvoor het loon wordt waargenomen mogelijk geen willekeurige selectie is uit de hele set waarnemingen. Is dit inderdaad het geval dan zullen de regressie coëfficiënten vertekend zijn. In een dergelijk model corrigeert de selectieterm voor dit probleem. 


\section{Tabel 5.5 (vervolg)}

Heckman selectiemodel voor het loon in t+12 (in log) (regressie coëfficiënten)

\section{Model 5}

Werkgelegenheidsgroei in sector (t-1)

$0,01^{* * *}$

Werk in zelfde sector

Ref

Werk in andere sector

0,00

Werk in andere*ontslag

0,00

Loon in t-12 (in log)

$0,57^{* * *}$

$\lambda$

$-1,01^{* * *}$

Constante term

$3,49^{* * *}$

Baankans

Geen ontslag

Ref

Faillissement

$-1,12^{* * *}$

UWV bedrijfseconomisch

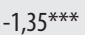

Collectief ontslag

$-1,01^{* * *}$

$\begin{array}{ll}\text { Vrouwen } & \text { Ref } \\ \text { Mannen } & 0,10^{*}\end{array}$

Leeftijd

0,01

Leeftijd kwadraat

$-0,00^{*}$

$\begin{array}{lc}\text { Loon in } \mathrm{t}-12(\text { in } \log ) & 0,29^{* * *} \\ \text { Constante term } & -0,31 \\ \mathrm{~N}^{1} & 8844\end{array}$

${ }^{*} \mathrm{p}<0,05 ;{ }^{* *} \mathrm{p}<0,01 ;{ }^{* * *} \mathrm{p}<0,001$

1 Het aantal waarnemingen in kleiner dan het aantal in tabel 3, omdat het model voor het loon in $\mathrm{t}-12$ controleert. Deze is missing voor mensen zonder baan op dat moment.

Bron: SSB

\subsection{Conclusie}

In dit hoofdstuk zijn wij ingegaan op de gevolgen van bedrijfseconomisch ontslag voor de arbeidsparticipatie en het loon. Wij sluiten hiermee aan bij recente ontwik- 
kelingen in de economische literatuur, en maken gebruik van de bij het CBS nieuw ontwikkelde data-infrastructuur. De CBS data maken het mogelijk om drie vormen van bedrijfseconomisch ontslag te onderscheiden: ontslag via UWV, faillissementen en collectieve uitstroom. Focussen op bedrijfseconomisch ontslag is interessant, omdat de reden voor het ontslag niet gerelateerd is aan de eigen schuld of specifieke kenmerken van de ontslagene. Bij andere vormen van werkloosheid is dat in meer of mindere mate wel het geval is. De door ons gebruikte databronnen lenen zich dus goed voor het meten van de gevolgen van ontslag op depreciatie van menselijk kapitaal. Immers, signaling van de productiviteit van de werknemer speelt in tegenstelling tot bijvoorbeeld ontslag door schuld geen grote rol. Een kanttekening hierbij is dat onze analyses hebben laten zien dat er wel degelijk verschillen zijn in de achtergrondkenmerken van de ontslagenen en niet-ontslagenen. Hierbij kan worden opgemerkt dat vooral de UWV-ontslagenen, wat hun persoons- en baankenmerken betreft, het meest op de niet-ontslagenen lijken. Vooral de vergelijking van UWV-ontslagenen met niet-ontslagenen biedt dus goede mogelijkheden om uitspraken te kunnen doen met betrekking tot depreciatie van menselijk kapitaal als gevolg van werkloosheid.

Onze analyses hebben laten zien dat ontslagwerklozen een kleinere participatiekans hebben in de jaren na ontslag vergeleken met een controle groep. Bovendien hebben onze analyses laten zien dat ontslag via het UWV of als gevolg van een faillissement significante negatieve gevolgen heeft voor het loon dat iemand na het ontslag verdient. Bij ontslag via de UWV is het loon in de nieuwe baan $13 \%$ lager vergeleken met niet-ontslagenen. Bij faillissement is de loonachterstand, wellicht als gevolg van de jongeren leeftijd en het lager loon voor ontslag, kleiner: $7 \%$. Echter, voor de collectief ontslagenen die weer werk vinden wordt een positief looneffect gevonden. Dit wijst erop dat collectief ontslag een gunstig effect heeft op de allocatie van arbeid, maar dit effect kan ook het gevolg zijn van het feit dat deze groep ontslagenen ook personen omvat die vrijwillig hun bedrijf hebben verlaten voor een betere baan elders.

Het spreekt voor zich dat de hier gepresenteerde analyses slechts een eerste aanzet zijn, en dat wij nog niet alle mogelijkheden van de data hebben benut. In vervolganalyses zou kunnen rekening worden gehouden met de duur van werkloosheid; immers indien er inderdaad sprake is van depreciatie van menselijk kapitaal tijdens een periode van ontslagwerkloosheid, dan kan worden verwacht dat dit effect groter zal zijn naarmate de duur van werkloosheid langer is. Ook zijn onze multivariate analyses nu nog beperkt tot de eerste I2 maanden na werkloosheid. Het zou interessant zijn om te kijken in welke mate de loonverschillen 2 of 3 jaar na ontslag blijven bestaan.

Dat sectorverandering na werkloosheid in onze analyses geen significant effect heeft op het loon is opmerkelijk, omdat eerdere studies hebben aangegeven dat het veranderen van sector als gevolg van werkloosheid tot verlies van specifiek menselijk kapitaal leidt. Vervolganalyses zouden hierop dieper in kunnen gaan. Dit zou bijvoorbeeld 
kunnen door de sectoren te karakteriseren naar de mate waarin het menselijk kapitaal in de sector specifiek of generiek is.

Een mogelijke kritiekpunt op de 'displaced worker' literatuur waar deze bijdrage op voortbouwt is dat er ook bij ontslagwerkloosheid sprake zou kunnen zijn van zelfselectie. Daar zou spraken van kunnen zijn indien werknemers op een massaontslag anticiperen en de meest kansrijke werknemers al voor de ontslaggolf hun bedrijf verlaten. Het monitoren van stromen van werknemers in en uit bedrijven in de maanden voor massaontslag zou hier meer zicht op kunnen werpen. 


\section{Conclusie en vervolgvragen}

In dit rapport is de vraag aan bod gekomen hoe iemands menselijk kapitaal zich over de levensloop ontwikkelt. Daarbij is gekeken naar de algemene ontwikkeling van het menselijk kapitaal naar leeftijd, alsook naar specifieke arbeidsmarktgebeurtenissen die van invloed kunnen zijn op de ontwikkeling van het menselijk kapitaal, in het bijzonder naar inactiviteit in verband met de zorg voor kinderen en werkloosheid als gevolg van bedrijfeconomisch ontslag.

De analyses rond functionele geletterdheid van mensen - proza, document en numerieke geletterdheid - hebben laten zien dat er gedurende de levensloop sprake is van een afname van verschillende vormen van geletterdheid. Omdat functionele geletterdheid een indicator is van bepaalde aspecten van iemands menselijk kapitaal, kunnen wij concluderen dat menselijk kapitaal deels deprecieert over de levensloop. Deze depreciatie van menselijk kapitaal doet zich vooral voor na de leeftijd van 40 jaar. Onze cohortvergelijking heeft laten zien dat in I4 jaar tijd de proza- en documentgeletterdheid gemiddeld genomen gedaald is met $4,6 \%$ en dat de numerieke geletterdheid met $2,5 \%$ is gedaald. Wij vinden geen grote verschillen naar geslacht, maar wel naar opleidingsniveau: laag opgeleiden hebben opmerkelijk genoeg minder last van depreciatie van menselijk kapitaal dan middelbaar en hoogopgeleiden, maar daar staat tegenover dat hun niveau van geletterdheid gemiddeld genomen lager is; zij hebben dus minder te verliezen. Ook geheugentesten laten zien dat iemands cognitie op oudere leeftijd afneemt. Deze afname in cognitie is groter bij uittrede uit het arbeidsproces. Deze bevinding is in lijn met de 'use it or lose it' hypothese.

Uit onze analyses van de eigen inschatting van de kennisontwikkeling - een subjectieve maatstaf voor de waarde van het menselijk kapitaal (kennis en vaardigheden) in de functie die men uitoefent - blijkt dat de kennis met het stijgen van de leeftijd steeds minder toeneemt om vervolgens, rond de leeftijd van 58 jaar zelfs af te nemen. Hierbij moet echter worden aangetekend dat het kennisniveau van werkenden niet daalt: de toename wordt steeds kleiner, maar nooit negatief. Bovendien blijkt dat de kennis van werkenden die de afgelopen twee jaar cursussen hebben gevolgd significant minder snel deprecieert.

Inactiviteit in verband met de zorg voor kinderen en werkloosheid kunnen depreciatie van menselijk kapitaal tot gevolg hebben, omdat in de periode waarin niet 
wordt gewerkt het menselijk kapitaal vaak voor een groot deel onbenut blijft. Dit kan resulteren in een lagere arbeidsparticipatie, een lager beroepsniveau of een lager loon. Onze analyses van de gevolgen van inactiviteit in verband met de zorg voor kinderen hebben laten zien dat er zowel voor vrouwen sprake is van een negatieve duurafhankelijkheid tussen de periode van inactiviteit en de kans op participatie. Er blijkt verder dat voor vrouwen die hun baan verlaten in verband met de geboorte van een kind, een langere periode van inactiviteit resulteert in een lager beroepsniveau na de periode van inactiviteit. Dit negatieve effect wordt echter gecompenseerd door de opgebouwde arbeidsmarktervaring in de jaren voor de loopbaanonderbreking. Dit is beleidsmatig interessant, omdat het betekent dat de kennis en vaardigheden die opgedaan zijn voor de loopbaanonderbreking niet volledig verloren gaan indien vrouwen zich voor een al dan niet langere tijd terugtrekken uit betaalde arbeid om voor de kinderen te zorgen. De depreciatievoet van menselijk kapitaal blijkt ook niet te verschillen tussen gemengde, mannen- en vrouwenberoepen.

In onze analyse van het effect van werkloosheid op de waarde van het menselijk kapitaal hebben wij de focus gelegd op bedrijfseconomisch ontslag. Dit hebben wij gedaan omdat de kans op werkloosheid in het algemeen selectief is, maar een minder belangrijke rol speelt bij bedrijfseconomisch ontslag. Wij hebben drie vormen van bedrijfseconomisch ontslag onderscheiden: ontslag via UWV, faillissementen en collectieve uitstroom. Vooral UWV ontslagen zijn wat hun achtergrondkenmerken betreft zeer vergelijkbaar met niet-ontslagenen. Dit suggereert dat selectiviteit in werkloosheid vooral voor de deze groep geen grote rol speelt. Onze analyses laten zien dat de drie groepen ontslagwerklozen in de jaren na ontslag een kleinere participatiekans hebben vergeleken met niet-ontslagenen. Bovendien laten onze econometrische analyses zien dat ontslag via UWV of als gevolg van een faillissement significante negatieve gevolgen heeft voor het loon dat iemand na het ontslag verdient. Voor de collectief ontslagenen die weer werk vinden wordt daarentegen een positief looneffect gevonden. Wij kunnen echter niet uitsluiten dat dit positief effect te wijten is aan het feit dat deze groep ontslagenen ook personen omvat die, vooruitlopend op het collectiefontslag, vrijwillig ontslag hebben genomen en een beter betalende baan hebben gevonden.

Aansluitend bij recente ontwikkelingen in de economische literatuur is in dit rapport gebruik gemaakt van databronnen die het mogelijk maken om de waarde van het menselijk kapitaal op directe wijze te meten (objectief, dan wel subjectief), en de effecten van specifieke - in surveys niet vaak voorkomende -arbeidsmarktgebeurtenissen (zoals bedrijfseconomisch ontslag) op het menselijk kapitaal te meten. Traditioneel maakt het onderzoek naar de waarde van het menselijk kapitaal gebruik van loongegevens; een indirecte manier om de waarde van het menselijk kapitaal vast te stellen. De reden hiervoor is de ruime beschikbaarheid van dergelijke data. Er kleven echter een aantal nadelen aan het gebruik van het loon om de waarde van iemands menselijk kapitaal vast te stellen: instituties op de arbeidsmarkt hebben een bepaalde loonrigiditeit tot gevolg, en het is mogelijk dat loonafspraken tussen werkgevers en werknemers een rol spelen. Ook aan het gebruik van directe indicatoren 
kunnen nadelen kleven: zo is het mogelijk dat deze slechts een deel van de vaardigheden meten die op de arbeidsmarkt gewaardeerd worden. Dit zou kunnen verklaren waarom directe en objectieve maatstaven voor het menselijk kapitaal (zoals bijvoorbeeld iemands functionele geletterdheid) eerder in de levensloop, in een periode waarin het loon blijft groeien, afnemen. Daar staat tegenover dat er een sterke positieve correlatie bestaat tussen de subjectief gemeten kennisontwikkeling enerzijds, en de loonontwikkeling anderzijds.

Nader onderzoek zou zich kunnen richten op het ontrafelen van deze complementariteit - en waarschijnlijk causale relatie - tussen directe maatstaven voor het menselijk kapitaal en het loon van werknemers. Voor beleid is dit belangrijk, omdat hierdoor het proces van loonvorming in relatie met de kennis en vaardigheden van werknemers beter begrepen kan worden. Met name op oudere leeftijd blijken iemands loon en algemene vaardigheden, zoals geletterdheid en geheugen, verder uit elkaar te liggen. Een interessante beleidsvraag is of dit veroorzaakt wordt door rigiditeit op de arbeidsmarkt, of doordat de arbeidsmarkt andere vaardigheden waardeert die meestal groeien wanneer iemand meer werkervaring heeft zoals bijvoorbeeld managementvaardigheden. Kortom, het zou kunnen dat sommige vaardigheden tijdens de levensloop depreciëren terwijl andere vaardigheden juist in waarde toenemen. In dit verband zou het interessant zijn om meer inzicht te krijgen in de taken die werknemers in hun baan en/of beroep uitoefenen en welke vaardigheden daarvoor noodzakelijk zijn. Tot zekere hoogte is onderzoek hiernaar mogelijk aan de hand van het beschikbare datamateriaal. Onderzoek op individueel niveau wordt echter belemmerd door de beperkingen van de beschikbare data. Doorgaans bevatten databestanden of loongegevens of indicatoren voor geletterdheid en cognitie, maar zelden beiden. Over de taken van werknemers is maar weinig systematische informatie beschikbaar.

Het benutten van data rond bedrijfseconomisch ontslag biedt perspectieven voor onderzoek naar de waarde van het menselijk kapitaal. Dergelijk onderzoek is beleidsmatig relevant omdat het de mogelijkheid biedt om het effect van werkloosheid op depreciatie van menselijk kapitaal te scheiden van het signaaleffect daarvan. In dit verband konden binnen het kader van dit onderzoek niet alle mogelijkheden van de data worden benut. Met name de vergelijking tussen werknemers die ontslagen zijn door eigen schuld en werknemers die slachtoffer zijn geworden van bedrijfseconomisch ontslag kan beleidmatig nuttige informatie opleveren, omdat bij de eerste groep wel een negatieve signaalfunctie kan uitgaan van iemands werkloosheid. 



\section{Bijlagen}

\section{Bijlage 1: gemiddelde en variantie van plausibele waarden}

Voor de berekening van het gemiddelde en de variantie van de plausibele waarden voor prozageletterdheid, documentgeletterdheid en numerieke vaardigheden gaan wij uit van de methode die Statistics Canada voorschrijft (Statcan 2002). ${ }^{34}$

\section{Gemiddelde}

Voor elke van de drie facetten van geletterdheid $k(k=\mathrm{I} \ldots 3)$ wordt uitgegaan van het gemiddelde van elk van de vijf verschillende plausibele waarden op het niveau van de respondenten, welke vervolgens gemiddeld worden voor de vijf plausibele waarden. Stel $p_{i j k}$ is een plausibele waarde voor individu $i(i=\mathrm{I} \ldots \mathrm{N})$ op item $j$ voor geletterdheid $k$ en $M$ is het aantal plausibele waarden (in het geval van ALL en IALS dus vijf), dan wordt het gemiddelde als volgt berekend:

$\overline{p_{k}}=\frac{1}{M} \sum_{j=1}^{M} \bar{p}_{j k}$, waarbij $\bar{p}_{j k}=\frac{1}{N} \sum_{i=1}^{N} p_{i j k}$.

\section{Variantie}

Als gevolg van de meetonbetrouwbaarheid in de plausibele waarden dienen variantie en standaardfout van de plausibele waarden aan de hand van aangepaste formules to worden berkend. De berekende variantie dient rekening to houden met de variantie van de imputatie van de verschillende plausibele waarden (zeg maar de meetfout) en met de steekproef variantie van $\bar{p}_{k}$.

34. De berekeningen zijn in Stata uitgevoerd met behulp van een door ons aangepaste versie van Kevin Macdonald's programma $\mathrm{p}$. 
De variantie van de imputatie kan worden berekend als

$V_{i m p, k}=\frac{1}{M-1} \sum_{j=1}^{M}\left(\bar{p}_{j k}-\bar{p}_{k}\right)^{2}$

De steekproef variantie dient rekening te houden met het feit dat de data verdeeld is in 30 willekeurige groepen van gelijke omvang. Dit is de zogenaamde jackknife replicatie methode (JKI) (Wolter, I985). Aan elke groep $g$ is een apart gewicht toegekend dat bij de berekening betrokken moet worden. Aan de hand van de gewichten kunnen dus 30 replicaties van de te schatten parameter worden verkregen voor elk van de 5 plausibele waarden. De steekproef variantie wordt aldus verkregen:

$V_{\text {steek }, k}=\frac{1}{5} \sum_{j=1}^{M} \frac{29 * \sum_{g=1}^{30}\left(\bar{p}_{j g k}-\bar{p}_{k}\right)^{2}}{30}$

De variantie van $\bar{p}_{k}\left(\sigma_{\bar{p}_{k}}^{2}\right.$ kan dan worden berekend als:

$\sigma_{p_{k}}^{2}=V_{\text {steek, }, k}+\left(1+\frac{1}{M}\right) V_{i m p, k}$ 


\section{Bijlage 2: Bedrijfseconomisch ontslag}

We maken in onze analyse gebruik van de recent beschikbaar gekomen SSB gegevens over bedrijfseconomisch ontslag in Nederland. We laten de resultaten zien van analyses op een bestand met ontslaggegevens over 2005:

I. Ingewilligde individuele ontslagaanvragen bij het UWV Werkbedrijf om bedrijfseconomische redenen;

2. Baanbeëindigingen binnen bedrijven die failliet gingen in 2005 of 2006 ;

3. Collectieve ontslagen die werden afgeleid uit het Sociaal Statistisch Bestand (SSB).

De ontslagen werknemers worden gevolgd tot 2008 en vergeleken met niet-ontslagen werknemers.

Registraties UWV Werkbedrijf gekoppeld aan het SSB-Banenbestand ( $N=35.000)$

In Nederland wordt de ene helft van de ontslagen ingediend bij het UWV Werkbedrijf (ontslagaanvragen), terwijl de andere helft (ontbindingsverzoeken) wordt afgehandeld door het Kantongerecht. Het UWV behandelt voornamelijk ontslagaanvragen wegens bedrijfseconomische redenen en arbeidsongeschiktheid. Ontslag loopt via het Kantongerecht als er bijvoorbeeld sprake is van een arbeidsconflict of als de UWV-procedure niet bevredigend is verlopen. Het integrale bestand van het UWV werd op persoonsniveau gekoppeld aan het SSB-Banenbestand, ter identificatie van de beëindigde baan (zie ook Corpeleijn, 2009; Van Gaalen \& Van Rooijen, 2009).

Rechtbankregistraties faillissementen gekoppeld aan het SSB-Banenbestand ( $N=31.000)$

In het geval van een faillissement is er geen ontslagvergunning benodigd. Faillissementen worden ontleend aan integrale rechtbankregistraties op bedrijfsniveau. Binnen die bedrijven worden baanbeëindigingen gerekend tot het faillissementsontslag in het jaar waarin het bedrijf failliet werd verklaard, of in het jaar daaraan voorafgaand. Baanbeëindigingen in het jaar voorafgaand aan het faillissement zijn meegenomen, omdat bedrijven meestal niet plotseling failliet gaan. Doorgaans gaat er enige tijd overheen tussen het moment waarop het bedrijf in de financiële problemen raakt en de uitspraak van het faillissement (zie ook Bloemendal, 20IO).

\section{Collectief ontslag: SSB-banenbestand $(N=14.000)$}

Omvangrijke ontslagrondes worden steeds vaker afgewikkeld via een sociaal plan, zonder dat er een andere instantie aan te pas komt (Scheele, Theeuwes, \& de Vries, 2007). In dergelijke gevallen gaan werkgever en werknemers met wederzijds goedvinden uit elkaar. Er is dan echter wel degelijk sprake is van onvrijwillige baandynamiek als gevolg van bedrijfseconomische calamiteiten, ook al is er juridisch vaak geen sprake van ontslag. 
De identificatie van collectieve ontslagen verloopt langs een aantal stappen (zie voor uitgebreide documentatie Scheele et al., 2008). De selectie voor collectief ontslag en de daarbij betrokken werknemers ziet er nu als volgt uit. Allereerst wordt de uitstroom bepaald in grotere bedrijven. Vervolgens wordt de aandacht gericht op reguliere banen in die bedrijven. Grotere bedrijven met een beperkt aantal reguliere banen worden uitgesloten. Dan wordt de doorstroom bij het doorstarten van bedrijven en bij fusies en splitsing van bedrijven uit de cijfers gehaald. Werknemers waarvan de arbeidsorganisatie grotendeels wordt overgedragen aan een ander bedrijf worden niet meegerekend. Werknemers die en masse naar een uitzendbureau doorstromen, worden daarentegen wel als collectief ontslag aangemerkt. Massaontslag wordt ten slotte gedefinieerd als pieken in de uitstroom. Om er geheel zeker van te zijn dat de in de voorgaande stappen geselecteerde werknemers daadwerkelijk bij een collectief ontslag betrokken zijn geweest, heeft nog een laatste filtering plaats gevonden. Aan een van de volgende mogelijkheden dient te zijn voldaan: tenminste een gedeelte van de werknemers ontvangt een WW-uitkering of een wachtgelduitkering of heeft zich ingeschreven bij het UWV. Daarbij is het volgende criterium toegepast: minimaal 5 procent van de vermeend ontslagen werknemers moet in de 6 maanden na de baanbeëindiging aan een van deze criteria voldaan hebben.

Niet-ontslagen werknemers: SSB Banenbestand $(N=100.000)$

Om te bepalen in hoeverre ontslagenen om bedrijfseconomische redenen verschillen van niet-ontslagenen wordt een vergelijkingsroep geformeerd: er wordt een aselecte steekproef getrokken uit de populatie werknemers (ruim 6 miljoen personen) die het gehele jaar werknemer waren. 


\section{Literatuur}

Abbring, J., G. van den Berg, P. Gautier, J. van Ours, G. van Lomwel, C. Ruhm (2002), Worker displacement in the US and the Netherlands. In P. Kuhn (ed), Losing work, moving on: international perspectives on worker displacement, W.E. Upjohn Institute for Employment Research, Kalamazoo, Michigan, 105-194.

Albrecht, J., P. Edin, M. Sundstrom, S. Vroman (1999), Career interruptions and subsequent earnings: A reexamination using Swedish data, The Journal of Human Resources, 34(2), 294-311.

Allen, J., A. de Grip (2007), Skill obsolescence, lifelong learning and labor market participation, ROA-RM-2007/6, Maastricht.

Agarwal, S., X. Gabaix, J. Driscoll, D. Laibson (2009), The age of reason: financial decisions over the life cycle and implications for regulation, Brookings Papers on Economic Activity, 2, 51-117.

Arrow, K. (1962), The economic implications of learning by doing, Review of Economic Studies, 3(8), 155-173.

Arthur, W., W. Bennett, P. Stanush, T. McNelly (1998), Factors that Influence Skill Decay and Retention: A Quantitative Review and Analysis, Human Performance, 11(1), 57-101.

Arts, C., B. Bakker, E. Van Lith (2000), Matching administrative registers and household surveys, Netherlands Official Statistics, 15 (Summer; Special Issue: Integrating administrative registers and household surveys), 16-22.

Arts, C., E. Hoogteijling (2002), Sociaal Statistisch Bestand 1998 en 1999, Sociaal-Economische Maandstatistiek, 12, 13-21.

Arulampalam, W. (2001), Is unemployment really scarring? Effects of unemployment experiences on wages, The Economic Journal, 111(475), F585-F606.

Aubert, P., E. Caroli, M. Roger (2006), New technologies, organisation and age: firm-level evidence, The Economic Journal, 116(509), F73-F93.

Bakker, B. (2002), Statistics Netherlands' approach to social statistics: the Social Statistical Dataset, OECD Statistics Newsletter, 11, 4-6.

Bakker, B. (2009), Trek alle registers open! Rede uitgesproken van het ambt van bijzonder hoogleraar Methodologie van registerdata voor sociaal-wetenschappelijk onderzoek, Vrije Universiteit Amsterdam, Amsterdam.

Bartel, A., N. Sicherman (1993), Technological change and retirement decisions of older workers, Journal of Labor Economics, 11, 162-183.

Beblo, M, E. Wolf (2002), Wage penalties for career interruptions: an empirical analysis for West Germany, ZEW Discussion Paper No. 02-45.

Ben-Porath, Y. (1967), The production of human capital and the life cycle of earnings, Journal 
of Political Economy, 75, 352-365.

Berg, G. van den, D. Deeg, M. Lindeboom, F. Portrait (2010), The role of early-life conditions in the cognitive decline due to adverse events later in life, IZA DP No. 4780

Blechinger, D., F. Pfeiffer (2000), Technological change and skill obsoloescence: the case of German apprenticeship training. In H. Heijke, J. Muyskens (eds), Education and training in a knowledge-based economy, Macmillan, London, 243-276.

Bloemendal, C. (2010), Wie verliezen hun baan bij faillissementen? Sociaaleconomische Trends, 2e Kwartaal, 49-53.

Bonsang, E., S. Adam, S. Perelman (2010), Does retirement affect cognitive functioning?, ROARM-2010/1.

Borghans, L., F. Green, K. Mayhew (2001), Skill measurement and economic analysis: an introduction, Oxford Economic Papers, 53(3), 375-384.

Borghans, L., B. Golsteyn, A. de Grip (2006), Meer werken is meer leren; Determinanten van kennisontwikkeling, CINOP, 's-Hertogenbosch.

Borghans, L., B. Golsteyn, A. de Grip (2007), Werkend leren, Economische Statistische Berichten, 92, 260-263.

Borghans, L., B. Golsteyn, A. de Grip, A. Nelen (2009), Leren op het werk; Ontwikkelingen en consequenties voor productiviteit en mobiliteit, Expertisecentrum Beroepsonderwijs, 'sHertogenbosch/Amsterdam.

Bosch, N., A. Deelen, R. Euwals (2010), Deeltijd als tijdelijk fenomeen? Voltijd en deeltijd over opeenvolgende geboortecohorten van vrouwen. In Batenburg, R., P. de Beer, J. Mevissen, K. Tijdens (eds), Arbeid in crisis?, Boom/Lemma, Den Haag.

Bosma, H.,M. van Boxtel, R. Ponds, P. Houx, J. Jolles (2003). Education and age-related cognitive decline: the contribution of mental workload. Educational Gerontology. 29, 165-173.

Buligescu, B, D. de Crombrugghe, G. Mentesoglu, R. Montizaan (2009), Panel estimates of the wage penalty for maternal leave, Oxford Economic Papers, 61, i35-i55.

Burda, M., A. Mertens (2001), Estimating wage losses of displaced workers in Germany, Labour Economics, 8, 15-41.

Carrington, W. (1993), Wage losses for displaced workers: Is it really the firm that matters? The Journal of Human Resources, 28, 435-462.

Cattell, R. (1983), Intelligence and national achievement, The Cliveden Press, Washington, DC.

Clarck, A., A. Knabe, S. Rätzel (2010), Boon or bane? Others' unemployment, well-being and job insecurity, Labour Economics, 17, 52-61.

Clarck, A., A. Oswald (1994), Unhappiness and unemployment, The Economic Journal, 104, 648-659.

Corpeleijn, A. (2009), Werkhervatting na ontslag: een vergelijking van oudere en jongere werknemers, Sociaaleconomische Trends, 2, 35-40.

Couch, K. (2001), Earnings Losses and Unemployment of Displaced Workers in Germany, Industrial and Labor Relations Review, 54, 559-572.

Davier, M. von, E. Gonzalez, R. Mislevy (2009), What are plausible values and why are they useful, IERI Monograph Series, Issues and Methodologies in Large-Scale Assessments, 2, 9-36.

De Graaf, N.D., P. De Graaf, G. Kraaykamp W. Ultee (1998), Family Survey Dutch Population 1998, Department of Sociology, Nijmegen University.

De Graaf, N.D., P. De Graaf, G. Kraaykamp, W. Ultee (2000), Family Survey Dutch Population 
2000, Department of Sociology, Nijmegen University.

De Graaf, N.D., P. De Graaf, G. Kraaykamp, W. Ultee (2003), Family Survey Dutch Population 2003, Department of Sociology, Nijmegen University.

De Grip, A. (2006), Evaluating human capital obsolescence. In: Human Capital and Labour Market Performance, European Commission \& OECD, Paris, 119-148.

De Grip, A., H. Bosma, D. Willems, M. Van Boxtel (2008), Job-worker mismatch and cognitive decline, Oxford Economic Papers, 60, 237-254.

De Grip, A., J. van Loo (2002), The economics of skills obsolescence: a review. In A. de Grip, J. van Loo, K. Mayhew (eds), The economics of skills obsolescence, Research in Labor Economics, 21, JAI Press, 1-26.

Edin, P., M. Gustavson (2008), Time out of work and skill depreciation, Industrial \& Labor Relations Review, 61, 163-180.

Euwals, R., R. de Mooij D. van Vuuren (2009), Rethinking retirement, CPB Special Publication, No. 80, Den Haag.

Fouarge, D. (2009), Effecten van crisis voor schoolverlaters, ESB, 94(4568), 554-556.

Fouarge, D., R. Muffels (2008), Part-time work and childbirth in Europe: Scarring the career or meeting working-time preferences? In R. Muffels (ed), Flexibility and employment security in Europe. Labour markets in transition, Edward Elgar, Cheltenham, 223-254.

Fouarge, D., R. Muffels (2009), Working part-time in the British, German and Dutch Labour Market: Scarring for the Wage Career?, Journal of Applied Social Science Studies, 129, $217-$ 226.

Fouarge, D., T. Schils (2009), The effect of early retirement incentives on the training participation of older workers, LABOUR, 23, 85-109.

Fouarge, D., A. Manzoni, R. Muffels, R. Luijkx (2010), Childbirth and cohort effects on mothers' labour supply: A comparative study using life-history data for Germany, the Netherlands and Great-Britain, Work Employment and Society, 24, 487-507.

Friedberg, L. (2003), The impact of technological change on older workers: evidence from data on computer use, Industrial and Labor Relations Review, 56, 511-529.

Gangl, M. (2006), Scar effects of unemployment: an assessment of institutional complementarities, American Sociological Review, 71, 986-1013.

Ganzeboom, H., P. De Graaf, D. Treiman (1992), A standard international socio-economic index of occupational status, Social Science Research, 21, 1-56.

Gibbons, R., L. Katz (1991), Layoffs and lemons, Journal of Labor Economics, 9, 351-380.

Görlich, D., A. De Grip (2009), Human capital depreciation during hometime, Oxford Economic Papers, 61, i98-i121.

Gregg, P., E. Tominey (2005), The wage scar from male youth unemployment, Labour Economics, 12, 487-509.

Gregory, M., R. Jukes (2001), Unemployment and subsequent earnings: estimating scarring among British men 1984-94, The Economic Journal, 111, F607-F625.

Hamermesh, D. (1987), The costs of worker displacement, The Quarterly Journal of Economics, $102,51-76$.

Heckman, J. (1979), Sample selection bias as a specification error, Econometrica, 47, 153-161.

Heckman, J., R. Robb (1985), Alternative methods for evaluating the impact of interventions: an overview, Journal of Econometrics, 30, 239-267. 
Hijzen, A., R. Upward, P. Wright (2010), The income losses of displaced workers, The Journal of Human Resources, 45, 243-269.

Horn, J., R. Cattell (1967), Age differences in fluid and crystallized intelligence. Acta Psychologica, 26, 107-129.

Houtkoop, W. (1999), Basisvaardigheden in Nederland, Max Goote Kenniscentrum, Amsterdam.

Hultsch, D., C. Hertzog, B. Small, R. Dixon (1999), Use it or lose it: engaged lifestyle as a buffer of cognitive decline in aging?, Psychology and Aging, 14, 245-263.

Jacobson, L., R. LaLonde, D. Sullivan (1993), Earnings losses of displaced workers, The American Economic Review, 83, 685-709.

Jones, S. (1995), Measuring adult basic skills: a literature review. In A.Tuijnman, I. Kirsch, D. Wagner (eds), Adult basic skills: Innovations in measurement and policy analysis, NCAL/ OECD, Philadelphia/Paris.

Kim, M-K., S. Polachek (1994), Panel estimates of male-female earnings functions, Journal of Human Resources, 29, 406-428.

Kirsch, I. (2001), The International Adult Literacy Survey (IALS): understanding what was measured, ETS Research Report RR-01-25.

Kletzer, L. (1998), Job displacement, Journal of Economic Perspectives, 12, 115-136.

Koeber, C., D. Wright (2006), Gender differences in the reemployment status of displaced workers human capital as signals that mitigate effects of bias, Journal of Socio-Economics, 35, 780-796

Krahn, H., G. Lowe (1998), Literacy utilization in Canadian workplaces, Mimeo, University of Alberta.

Kriechel B. (2010), Displaced workers, unemployed and vocational education and training. In: P. Peterson, E. Baker, B. McGaw, (eds), International Encyclopedia of Education, volume 8, Elsevier, Oxford, 275-279.

Kriechel, B., G. Pfann (2005), The role of specific and general human capital after displacement, Education Economics, 13, 223-236.

Kriechel, B. (2003), Heterogeneity among displaced workers, Ph.D. thesis, Maastricht University.

Kuijvenhoven, L., S. Scholtus (2010). Estimating accuracy for statistics based on register and surveys, Statistics Netherlands, Den Haag.

Layte, R., H. Levin, J. Hendrickx, I. Bison (2000), Unemployment and cumulative disadvantage in the labour market. In: D. Gallie, S. Paugam (eds), Welfare regimes and the experience of unemployment in Europe, Oxford University Press, Oxford, 153-174.

Lazear, E. (1979), Why is there mandatory retirement?, Journal of Political Economy, 87, 1261 1284.

Leuven, E., H. Oosterbeek, H., H. Van Ophem (2004), Explaining international differences in male wage inequalities by differences in demand and supply of skills, The Economic Journal, 114, 466-486.

Luijkx, R., M. Wolbers (2009), The effects of non-employment in early work-life on subsequent employment chances of individuals in the Netherlands, European Sociological Review, 25, 647-660.

MacDonald, G., M. Weisback (2004), The economics of has-beens, Journal of Political Economy, 112, s289-s310. 
McDowell, J. (1982), Obsolescence of knowledge and career publication profiles: some evidence of differences among fields in costs of interrupted careers, American Economic Review, $72,752-768$.

Mincer, J. (1981), The economics of wage floors, NBER Working Paper No. W0804.

Mincer, J., H. Ofek (1982), Interrupted work careers: depreciation and restoration of human capital, The Journal of Human Resources, 17, 3-24.

Mincer, J., S. Polachek (1974), Family investments in human capital: earnings of women, Journal of Political Economy, 82, S76-S108.

Mooi-Reçi. I. (2008), Unemployed and scared for life? Longitudinal analyses of how unemployment and policy changes affect re-employment careers and wages in the Netherlands, 1980-2000, Vrije Universiteit, Amsterdam.

Muffels, R., D. Fouarge (2002), Working profiles and employment regimes in Europe, Journal of Applied Social Science Studies, 122, 85-110.

Murray,T, I. Kirsch, L. Jenkins (1997), Adult Literacy in OECD Countries: Technical Report on the First International Adult Literacy Survey. United States Department of Education, Washington, D.C.

Neal, D. (1995), Industry-specific human capital: evidence from displaced workers, Journal of Labor Economics, 13, 653-677.

Nelen, A., A. de Grip (2009), Why do part-time workers invest less in human capital than fulltimers? LABOUR, 23, 61-83.

Neuman, S., A. Weiss (1995), On the effects of schooling vintage on experience-earnings profiles: theory and evidence, European Economic Review, 39, 943-955.

Pissarides, C. (1992), Loss of skill during unemployment and the persistence of employment shocks, The Quarterly Journal of Economics, 107, 1371-1391.

ROA (2009), De arbeidsmarkt naar opleiding en beroep tot 2014, ROA-R-2009/5, Universiteit Maastricht.

Rohwedder, S., R. Willis (2010), Mental retirement, Journal of Economic Perspectives, 24, 1-20.

Román, A., D. Fouarge, R. Luijkx (2004), Career consequences of part-time work: results from Dutch panel data 1990-2001, OSA-publicatie A206, Tilburg.

Rosen, S. (1972), Learning and experience in the labour market, Journal of Human Resources, 7, 326-342

Rosen, S. (1975), Measuring the obsolescence of knowledge. In F. Juster (ed), Education, income and human behavior, Carnegie Foundation, New York, 199-232.

Ruhm, C. (1991), Are workers permanently scarred by job displacements?, American Economic Review, 81, 319-324.

Salthouse, T. (2006), Mental exercise and mental aging: evaluating the validity of the use it or lose it hypothesis, Perspectives on Psychological Science, 1, 68-87.

Scheele, D., J. Theeuwes, G. de Vries (2007), Arbeidsflexibiliteit en ontslagrecht, Amsterdam University Press, Amsterdam.

Scheele, D., R. van Gaalen, J. van Rooijen (2008), Werk en inkomsten na massaontslag: de zekerheid is niet van de baan, Amsterdam University Press, Amsterdam.

Schils, T., D. Fouarge, M. Kerkhofs (2006), Loon en werk na werkloosheid, OSA publicatie A221, Tilburg.

Song, Y. (2009), Training, technological changes, and displacement, Journal of Labor Research, 
30, 201-218.

Statcan (2002), The Adult Literacy and Life Skills Survey, 2003. Public Use Microdata File. User's Manual, Statistics Canada, Ottawa.

Sticht, T., R. Hofstetter, C. Hofstetter, C. (1996), Assessing adult literacy by telephone, Journal of Literacy Research, 28, 525-559.

Thijssen, J., E. Walter (2006), Obsoletie van oudere personeelsleden, Tijdschrift voor HRM, 9, 45-60.

Ultee, W., H. Ganzeboom (1993), Netherlands Family Survey 1992-1993, in Department of Sociology, Nijmegen University.

Van den Berg, G., D. Deeg, M. Lindeboom, F. Portrait (2010), The role of early-life conditions in the cognitive decline due to adverse events later in life, IZA DP 4780.

Van Gaalen, R., J. Van Rooijen (2009), Participatie en inkomsten na collectief en individueel ontslag om bedrijfseconomische redenen, Tijdschrift voor Arbeidsvraagstukken, 25, 201206.

Van Klaveren, C., A. Heyma (2008), Employability naar bedrijfsomvang, SEO-rapport 2008-57, Amsterdam.

Van Loo, J., A. de Grip, M. de Steur (2001), Skills obsolescence: causes and cures, International Journal of Manpower, 22, 121-137.

Venezky, R. (1992), Matching literacy testing with social policy: what are the alternatives?, National Center on Adult Literacy, Philadelphia, PA.

Weesie, J., M. Kalmijn (1995), Households in the Netherlands 1995, ICS/ISCORE, Utrecht University.

Weinberg, B. (2002), New technologies, skills obsolescence, and skill complementarity. In: A. De Grip, J. van Loo, K. Mayhew (eds), The economics of skills obsolescence, Research in Labor Economics, 21, JAI Press, 101-118.

Wolter, K. (1985), Introduction to variance estimation, Springer-Verlag, New York. 